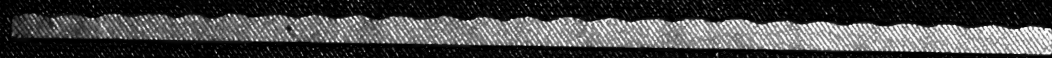

\title{
ANIMAL LIFE of the CARLSBAD CAVERN
} VERNON BAILEY 


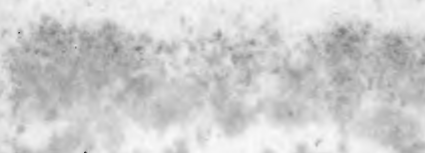

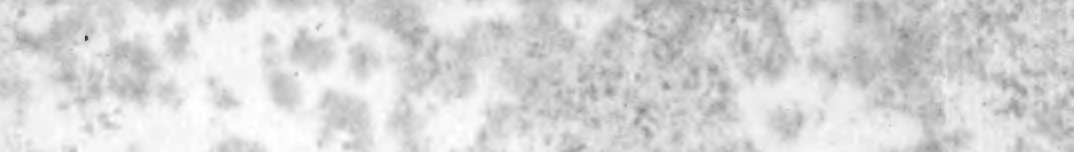

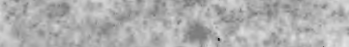

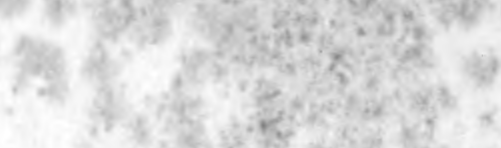

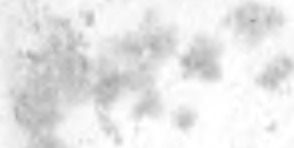

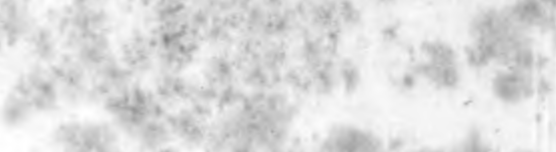

196.

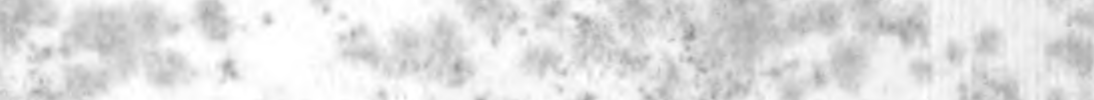

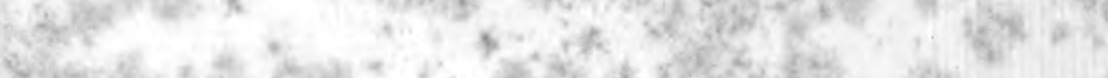
Q

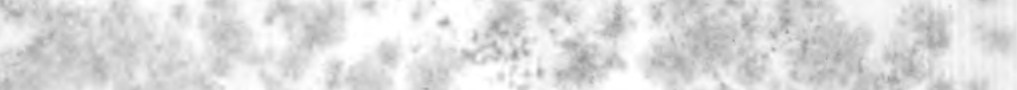

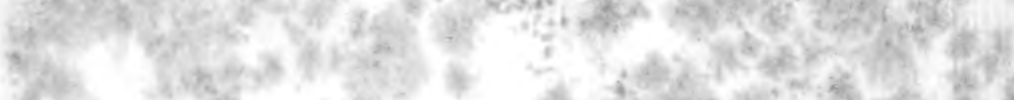

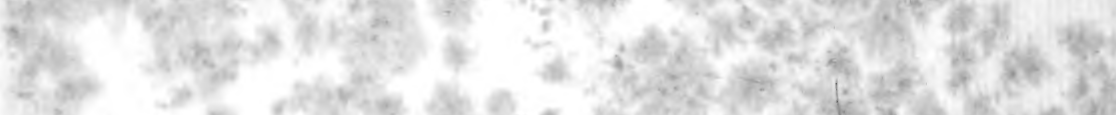

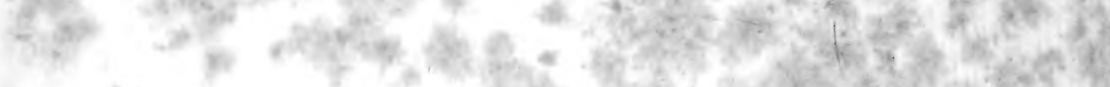
$+$
2.

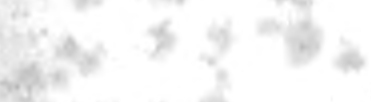

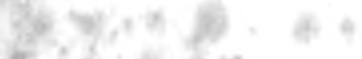

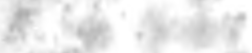

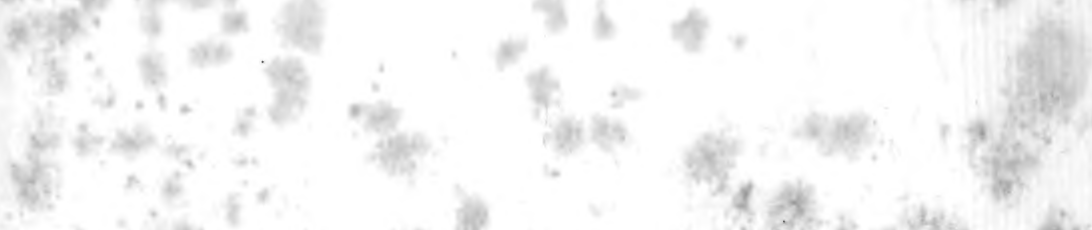
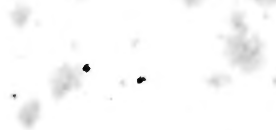

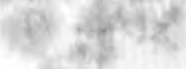

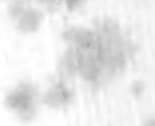
W. $* 6^{\circ}+i^{\circ}$
.

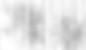

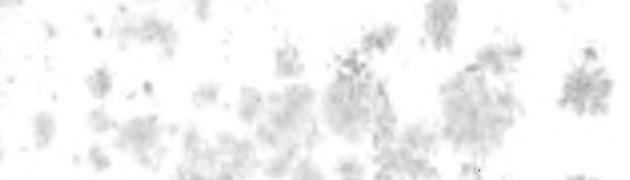

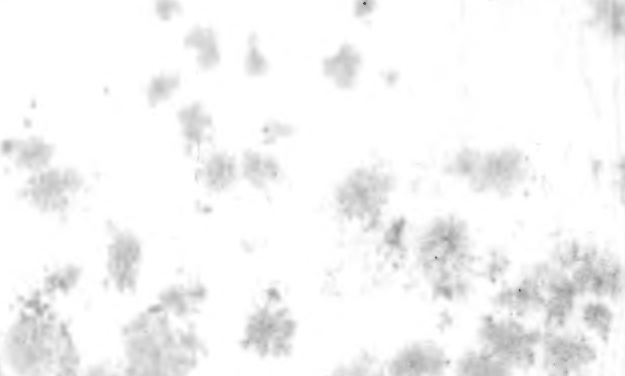

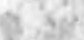

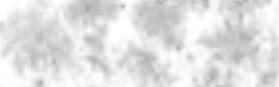

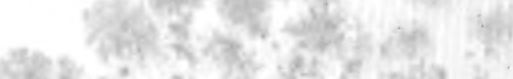

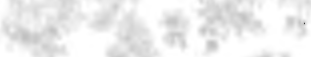

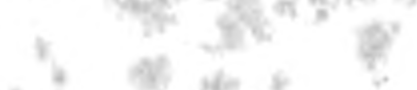

vent 4

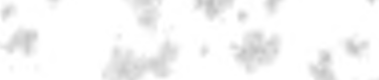

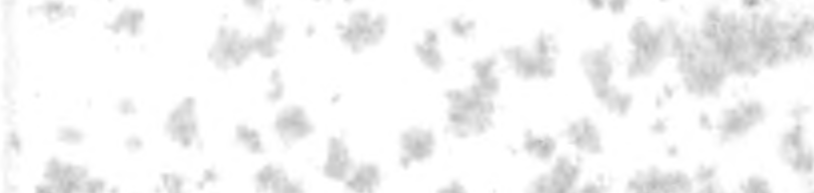

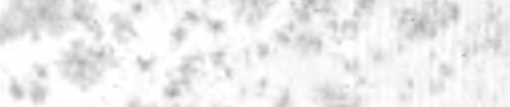

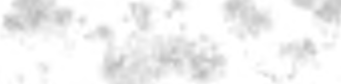

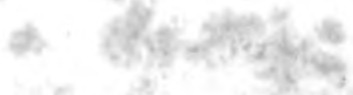

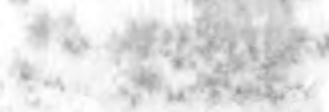




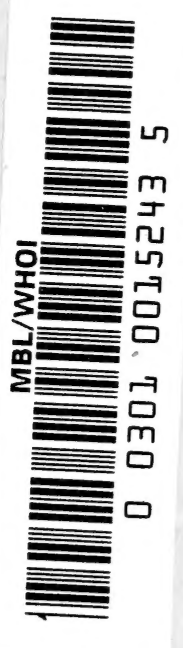

$\$ 3,0^{0}$ 



\section{MONOGRAPHS OF THE \\ AMERICAN SOCIETY OF MAMMALOGISTS}

These monographs are a series of publications similar in character to articles published in The Journal of Mammalogy, but not suitable for periodical publication because of their length or for other reasons.

The plans for this Series are broad and comprehensive, and contemplate the publication of works covering all phases of technical and popular Mammalogy.

The Monographs and The Journal of Mammalogy are issued under the auspices of the American Society of Mammalogists.

Information regarding these monographs may be obtained from the Secretary of the American Society of Mammalogists, A. Brazier Howell, U. S. National Museum, Washington, D. C., or the Publishers, The Williams \& Wilkins Company, Baltimore, U. S. A.

This series is edited by Hartley H. T. Jackson, Bureau of Biological Survey, Washington, D. C. Edward A. Preble, Ethel M. Johnson and Emma M. Charters assisted in editing Monograph 3. 


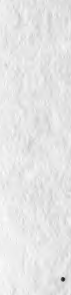




\section{MONOGRAPHS OF THE AMERICAN SOCIETY OF MAMMALOGISTS}

1. Anatomy of the Wood Rat. A. Brazier Howell, U. S. Biological Survey, Washington, D. C. 225 pages. $\$ 5.00$.

2. The Beaver. Edward R. Warren, Colorado Springs, Colorado. 177 pages. $\$ 3.00$.

3. Animal Life of the Carlsbad Cavern. Vernon Bailey, Washington, D. C. 195 pages. $\$ 3.00$.

Other titles will be announced

Prices are net postpaid

The American Society of Mammalogists participates in the profits from the sale of monographs. These profits are used to assist in publishing such monographs that could not be undertaken unless underwritten. 



\section{ANIMAL LIFE OF THE CARLSBAD CAVERN}






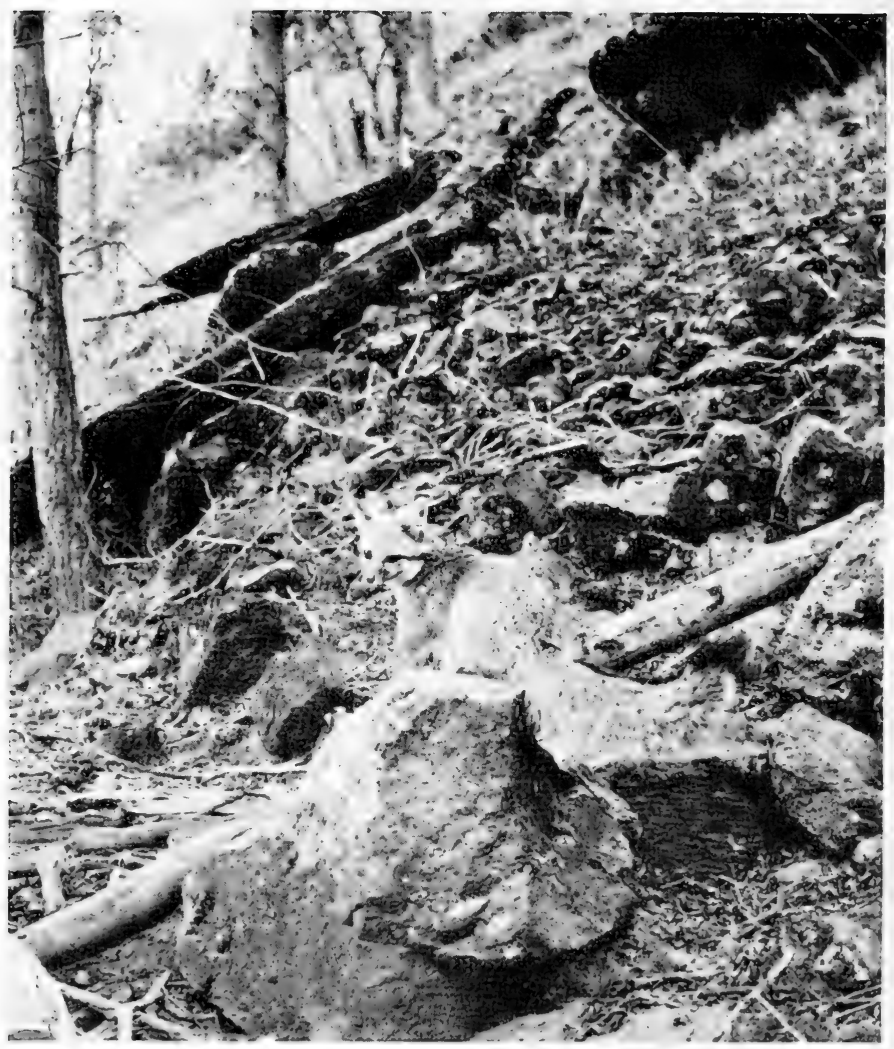

The Gray Fox (Urocyon CINereoargenteus scotTiI) These pretty little foxes inhabit the canyons and smaller caves 


\title{
Animal Life
}

OF THE

\section{Carlsbad Cavern}

\author{
BY \\ VERNON BAILEY
}

Biologist, United States Biological Survey

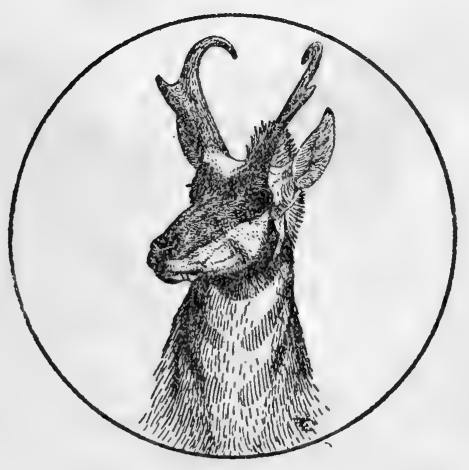

BALTIMORE

THE WILLIAMS \& WILKINS COMPANY 
Copyright 1928

THE WILLIAMS \& WILKINS COMPANY

Made in the United States of America

Published February, 1928

Composed and Printed at tha

WAVERLY PRESS

FOR

The Whutams \& Winkins Compayy

Baltmore, MD., U. S. A. 


\section{CONTENTS}

List of Illustrations $\ldots \ldots \ldots \ldots \ldots \ldots \ldots \ldots \ldots \ldots \ldots \ldots \ldots$

\section{CHAPTER 1}

Location and General Features of the Cavern........... 1

CHAPTER 2

Life Zones of the Carlsbad Region................... 7

CHAPTER 3

Conspictous Vegetation of the Region................ 20

CHAPTER 4

Animals and Plants of the Region in Relation to the ABORIGINES.............................. 39

CHAPTER 5

Mammals of the Region

CHAPTER 6

Birds of the REgION.

CHAPTER 7

Reptiles of the Region.......................... 163

CHAPTER 8

Invertebrates of the Carlsbad Cavern............... 171 



\section{LIST OF ILLUSTRATIONS}

The gray fox (Urocyon cinereoargenteus scottii)......... frontispiece

Fig. 1. Life zones of the Carlsbad Cavern region of New Mexico and Texas................................ 9

Fig. 2. Sketch map of Carlsbad Cavern with diagrammatic cross sections............................ 10

Fig. 3. West entrance to the Carlsbad Cavern.............. 13

Fig. 4. Inside room at west entrance to cave............. 14

Fig. 5. The floor of the lowest room in the cave........... 23

Fig. 6. The mesquite tree (Prosopis glandulosa) full of fruit... 24

Fig. 7. The narrow-leaved yucca (Yucca radiosa) in fruit.... 35

Fig. 8. The small mescal (Agave lechuguilla) in flower........ 36

Fig. 9. Sotol plant with full grown flower stem fifteen feet

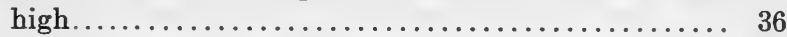

Fig. 10. The large mescal (Agave wislizeni) in flower........ 36

Fig. 11. Old mescal pit where the Indians roasted agaves..... 41

Fig. 12. A single well developed mescal or agave plant fit for roasting............................. 41

Fig. 13. Indian grinding-holes just in front of the Carlsbad Cavern................................ 42

Fig. 14. Indian grinding-holes just in front of the Carlsbad Cavern............................. 42

Fig. 15. An old bull buffalo charging the camera............ 51

Fig. 16. A trio of mountain sheep in Yellowstone Park....... 52

Fig. 17. Entrance to large cave in Slaughter Canyon not far from

Carlsbad, New Mexico....................... 52

Fig. 18. Jack rabbit in open valley.................... 63

Fig. 19. Small cottontail (Sylvilagus auduboni minor)......... 63

Fig. 20. A prairie-dog town in an alfalfa field............... 64

Fig. 21. The prairie-dogs build mounds about their burrows... 64

Fig. 22. The cave mouse (Peromyscus leucopus texensis)...... 71

Fig. 23. The cliff mouse (Peromyscus boylii rowleyi)......... 71

Fig. 24. Grasshopper mouse (Onychomys torridus torridus)..... 72

Fig. 25. Texas cotton rat (Sigmodon hispidus texianus)........ 72

Fig. 26. The white-throated wood rat (Neotoma albigula) ..... 77

Fig. 27. House of the gray wood rat (Neotoma micropus can-

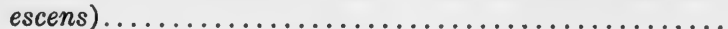


Fig. 28. The banner-tail (Dipodomys spectabilis baileyi)....... 78

Fig. 29. The banner-tail (Dipodomys spectabilis baileyi)....... 78

Fig. 30. Little four-toes (Dipodomys merriami merriami)...... 87

Fig. 31. Little four-toes (Dipodomys merriami merriami)....... 87

Fig. 32. The large pocket gopher (Cratogeomys castanops)..... 88

Fig. 33. The large pocket gopher (Cratogeomys castanops)...... 88

Fig. 34. The large pocket gopher (Cratogeomys castanops)..... 88

Fig. 35. Texas skunk (Mephitis mesomelas varians)........... 99

Fig. 36. Hog-nosed skunk (Conepatus mesoleucus mearnsi)...... 99

Fig. 37. Little spotted skunk (Spilogale leucoparia).......... 100

Fig. 38. The ring-tailed cat (Bassariscus astutus flavus)....... 100

Fig. 39. Guano bat (Tadarida mexicana mexicana).......... 109

Fig. 40. Guano bat (Tadarida mexicana mexicana).......... 109

Fig. 41. Little canyon bat (Pipistrellus hesperus)........... 109

Fig. 42. The house bat (Myotis incautus)................ 109

Fig. 43. Jack-rabbit bat (Corynorhinus macrotis pallescens) . .. 110

Fig. 44. Jack-rabbit bat (Corynorhinus macrotis pallescens).... 110

Fig. 45. Big brown bat (Eptesicus fuscus fuscus)............ 110

Fig. 46. Entrance of bat cave in Dow's Pasture, four miles west of Carlsbad............................. 127

Fig. 47. Slaughter Cave in Slaughter Canyon............. 127

Fig. 48. Entrance of McKittrick Cave, about fifteen miles west of Carlsbad............................. 128

Fig. 49. Entrance of Sevoya Cave, nineteen miles north of San

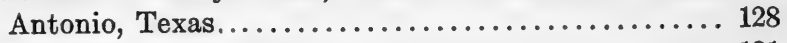

Fig. 50. Scaled quail, blue quail, or cotton-top............ 131

Fig. 51. Cactus wren. The sun singer................. 132

Fig. 52. Nest of the cactus wren in cactus bush............ 137

Fig. 53. The cane cactus (Opuntia arborescens) in fruit........ 137

Fig. 54. Canyon wren. A true cave dweller............. 138

Fig. 55. Two regurgitated pellets of the great horned owl..... 143

Fig. 56. Curve-billed thrasher's nest in Spanish bayonet...... 153

Fig. 57. White-necked raven's nest in top of tree yucca........ 153

Fig. 58. Western bull snake....................... 165

Fig. 59. Diamond-backed rattlesnake from Texas........... 165

Fig. 60 . The prairie rattlesnake.................... 166

Fig. 61. Black-tailed rattlesnake from Texas............. 166

Fig. 62. Scaly lizard (Sceloporus clarkii)................ 167 
Fig. 63. Desert whip-tailed lizard (C'nemidophorus tessellatus) at Carlsbad Cavern....................... 167

Fig. 64. Tiger lizard (Crotaphytus wislizenii).............. 168

Fig. 65. Western collared lizard (Crotaphytus collaris baileyi).. 168

Fig. 66. Horned toad (Phrynosoma cornutum).............. 173

Fig. 67. The vinegaroon or whip scorpion.............. 173 



\section{CHAPTER 1}

Location and General Features of the Cavern

In the Pecos River Valley of southeastern New Mexico, some twenty-six miles southwest of Carlsbad and half as far from the Texas line, lies the most extensive and spectacular cavern yet discovered in America, if not in the world. Set in the foothills of the Guadalupe Mountains and the heart of the desert, its appealing interests have already attracted from all over the country thousands of visitors whose numbers are ever increasing with better roads and improved means of access.

The cave may be reached from the east by the Santa Fe railroad to Carlsbad, or from the west by the Southern Pacific to El Paso, or the Texas and Pacific to Van Horn, Texas. The only automobile roads now available are from Carlsbad, Pecos, Van Horn, El Paso, Tularosa, and Roswell, but these conditions will not long persist. With the Painted Caves at the mouth of the Pecos and the Grand Canyon of the Rio Grande near Presidio del Norte on the south, the Painted Desert and Grand Canyon of Arizona on the west, and the series of national parks,-Rocky Mountain, Yellowstone, and Glacier,- on the north, the scenic roads of the future will not for long ignore this subterranean wonderland.

Before reaching the cave from any of the ordinary lines of travel, a long ride over level stretches of desert 
roads, whether from Carlsbad, Van Horn, or El Paso, will keep the tourist interested in the quaint forms of plant and animal life not found outside of desert regions. If the visitor should be so fortunate as to arrive in flowering time in April or May, and after a rain, the desert flora will burst upon him in the height of its marvelous bloom, not rivaled by the tropics. Many a desert thorn is then hidden by soft, glowing petals or fresh green leaves that later drop away and leave on all sides the repellent and threatening thorns.

Though known commercially for many years from its rich deposits of bat guano, for as much as one hundred thousand tons of this valuable fertilizer have been shipped from the one great bat-room, the Carlsbad Cavern and its scenic wonders were first made known to the general public through the National Geographic Magazine of January, 1924, shortly after it had been set aside as the Carlsbad National Monument by proclamation of President Coolidge on October 25, 1923. The guano deposit was then nearly exhausted and could no longer be worked at a profit, and the cave was thus rescued for the public before being injured by vandals, or by further commercialization.

A thorough study of its geology, structure, formation, extent, and animal and plant life was planned and carried out by the National Geographic Society. The late Dr. Willis T. Lee, of the Geological Survey, was placed in charge of the explorations, and it was my good fortune to assist him in a study of the animal life of the cavern and vicinity during the spring and early summer of 1924 . 
The Carlsbad Cavern is the largest, most spectacular, and best known of the numerous caves in the vicinity. Some of its striking features are enormous rooms and miles of vaulted hallways. The largest single room is four hundred and fifty feet wide and two hundred and fifty feet high; others approach it in size. The lowest point in the cave floor is some seven hundred feet below the level of the entrance, and the linear extent of the various rooms, halls, and passageways reaches for so many miles that days are necessary for exploring only those that are well known.

Some of the rooms are dry and dusty, some are moist from overhead stalactites, from the points of which the mineral-laden water is slowly building up groups of graceful stalagmites on the floor below, or is forming pools of good drinking water in lime-encrusted bowls and basins. In one of the basement rooms named the rookery, these drops of water form clusters of elongated or spherical nodules called "cave pearls," resembling birds' eggs of various sizes and shapes. Dry beds of old streams are observed, which once were potent factors in carving the cavern out of the solid limestone rock, or dissolving the beds of gypsum and rock salt that once filled some of the vaulted cavities, but no permanent running stream has been found in the cave in recent times.

To the geologist and mineralogist the graceful, the quaint, the grotesque, the massive secondary rock formations decorating the interior of the cave are of especial interest; but to the biologist the dry and dusty rooms where animal bones and tracks have been pre- 
served for years, and where the bats hang up on the walls or ceilings for their winter sleep, are still more attractive. Naturally, the greatest abundance of animal life is near the entrance to the cave where a trace of twilight filters into the darkness, where some plant and animal food falls in, and where lichens grow on the exposed rocks, and moulds cover the damp floor and decaying guano. Most of the insects and other small creeping life of the cave are found in the first large hall on either side of the main entrance, but some of the cave crickets go to the farthest corners of the galleries as do also the mice and cave cats or ring-tails.

The main entrance to the cavern opens into the side and near the top of a high limestone ridge, which rises abruptly about one thousand feet above the valley bottom and is reached by a well graded road leading up some three miles of the picturesque Walnut Canyon to the spring, and then over the top of the ridge to the great western doorway. Another natural opening about one thousand five hundred feet farther east is a mere break in the roof, near which two elevator shafts have been blasted out. The great western doorway now occupied by the stairway for descent to the first floor of the cavern is a wide, arched portal as picturesque as it is suggestive of ominous depths, making a fitting gateway to this subterranean world. Here in the shelter of the high arched portal, the animals, from Indians to bats, have gathered through the ages to take advantage of the protection of darkness and the warmth of the cave air, that varies but little throughout the year. Here the recently built steps go down 
into the first great room of the cave, from which the bat guano has been removed, and from this stairway graded trails lead down over masses of broken rock debris, over clean rock floors, down steep inclines and through vast rooms and halls among the silent, fantastic growths and quaint forms of crystal structure in this great laboratory of Nature, where no breath of air has ever stirred the delicate tracery of growing rocks. Here in these solemn depths, wrapped in the soft, moist air that feels fresh and inviting in the nostrils, surrounded by the velvety darkness that yields grudgingly to the little circle of the gasoline lantern or the narrow blade of a flashlight, and swallowed up in a vast soothing silence, one realizes the spell that for ages has held the hearts of man and beast. With a prattling crowd this may not be felt, but alone, and especially at night, the spell is all about and always the same restful, soothing charm.

On a hot day in summer the peace and quiet of the cave are best realized on returning to the glare, heat, and noise of the surface, but scarcely more so than on a cold day in winter, on coming from the mild soft air below into the piercing blasts that shriek and howl outside.

The study of the cave life has been by no means exhaustive, either inside or around the entrance, but enough material has been gathered to give a better understanding of what is seen for the first time and to form a starting point, a foundation, for more detailed and extensive work in the future. The conditions in the cave itself can not be fully understood without some 
knowledge of the climate, physiography, and general features of the region, all of which contribute their own especial interests toward the pleasure of a visit to the cave. 


\section{CHAPTER II}

\section{Life Zones of the Carlsbad Region}

Climatic conditions are reflected in the native plant and animal life of any region, not only in the dominance of peculiar species and the development of such characteristics as best served the plants and animals in their habitat, but in the absence of species developed under different climatic conditions. An occasional hot or cold, wet or dry, year usually has little effect, as the local plant and animal life is the product and the index of average climatic conditions over a long period of time.

The life of the Tropics is strikingly different from that of the Temperate zones, as is the life of these zones from that of the Arctic zone, but the humid and arid Tropics are also widely different in fauna and flora. Likewise, in the several well recognized transcontinental life zones between the Tropics and the Arctic there are many subdivisions based on the effects of peculiarities of climate, mainly of different degrees of humidity. The broad zones of similar climatic conditions extending across the continent have a fundamental basis of temperature, as has been shown by numerous authors since the time of Humboldt. However, the details of variation have been only partially determined by recent investigations in the field, and by actually mapping the geographic distribution of many species of plants and animals. In New Mexico and Texas this has been done in considerable detail and the life zones and their 
subdivisions have been mapped and described by the U. S. Biological Survey for each of the two states. The map (Fig. 1) shows in greater detail the topography of the Carlsbad Cave region, with such additions of local information as have been gathered during the explorations of the National Geographic Society in the vicinity of the caves.

Two of the well recognized life zones of North America meet and blend at the Carlsbad Cave: the Lower Austral, colored orange on the map, from below, and the Upper Austral, shown in yellow on the map, from above, while only fifteen miles to the westward the higher and cooler Transition zone, tinted blue, extends along the crest of the Guadalupe Mountains, and the still higher and colder Canadian zone, in green, follows the crest of the Sacramento Range some seventy-five miles to the northwest. These four life zones, as here shown by colors, afford a much greater variety and richness of life in a restricted area than could possibly be found in one uniform type of environment. They also mean a wider range of crop, fruit, and forest products than can be found in one life zone, as well as more varied and stimulating living conditions for man.

The Lower Austral zone, or the Lower Sonoran arid division of it, covers the Pecos and Rio Grande valleys and the low country between up to an altitude of about five thousand feet on south slopes and to about four thousand feet on the cooler north slopes. These limits vary, however, with the steepness of slopes, the steeper warm slopes (southern exposure) receiving more of the 


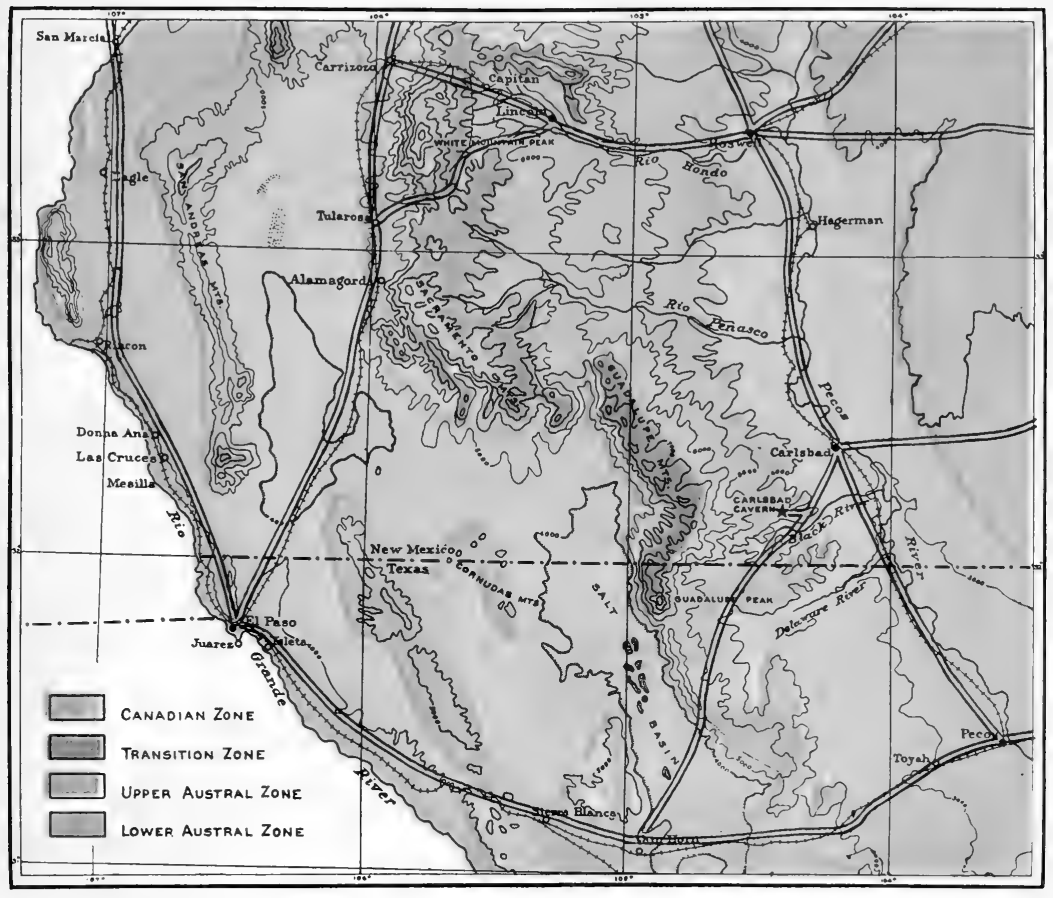

Fig. 1. Life Zones of the Carlsbad Cavern Region of New Mexico and TeXas

By Vernon Bailey, Biological Survey, U. S. Department of Agriculture 


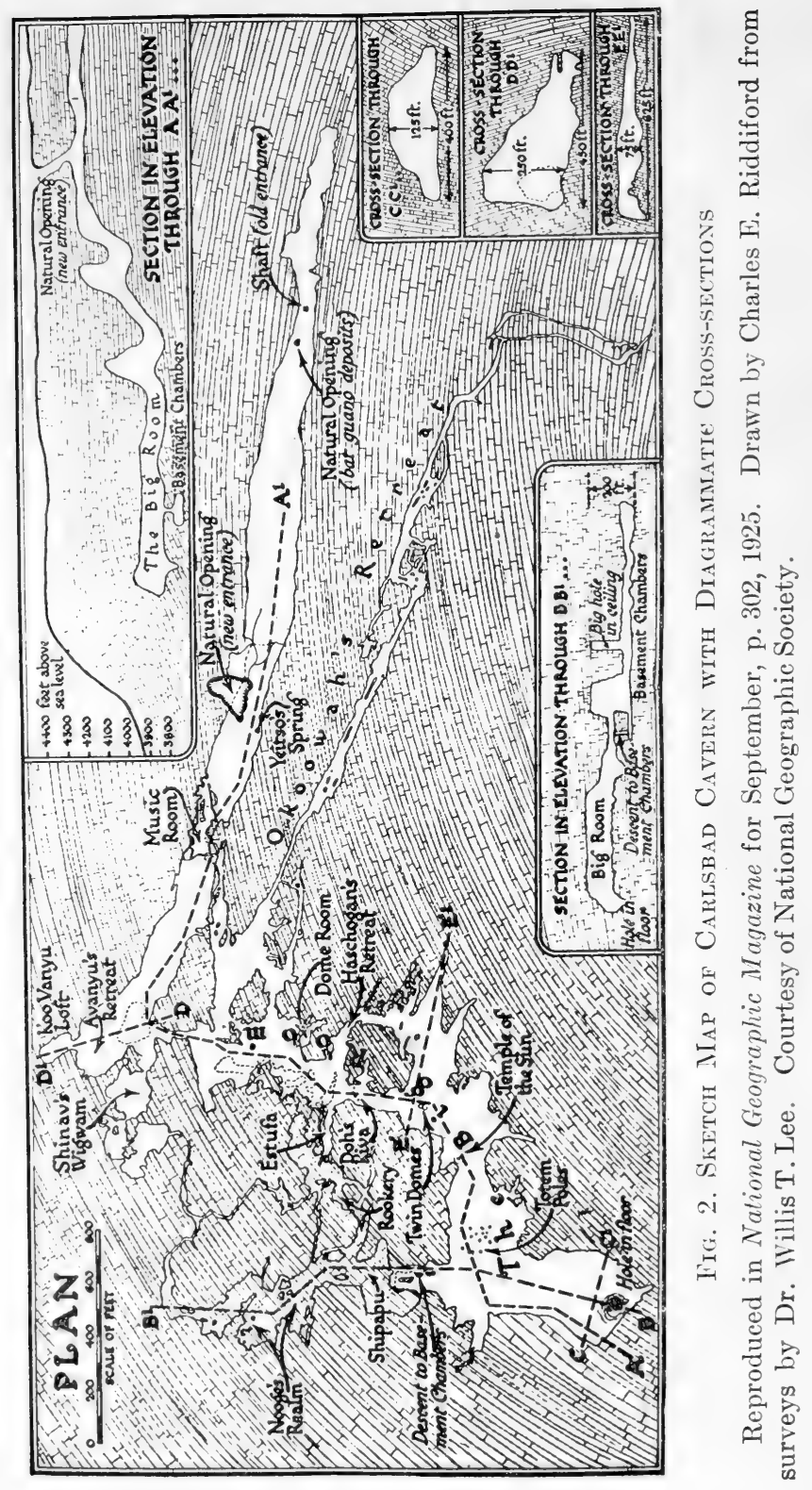


sun's rays and heat, and the steeper cold slopes (northern exposure) being more completely cut off from light and heat. On opposite sides of high ridges or deep canyons running in a general east and west direction there is often a difference of one thousand feet in the zone levels on slopes facing north or south, as shown by the plant and animal life. These differences are due to actual differences in temperature, as may be seen where the snow lies long on north slopes and disappears quickly on south slopes. The effect of slope exposure in this region of ridges and canyons must also be kept in mind to avoid confusion in regard to the distribution of species, and the extent of life zones. It should also be noted that each zone blends into the others and is nowhere sharply defined or bounded by a line.

The Lower Austral zone is here clearly marked by such characteristic shrubs as the creosote bush, mesquite, Acacia constricta, ocotilla, allthorn, blue-thorn, desert willow, three-leaved barberry, small-leaved sumac, green sumac, Mexican buckeye, varnish bush, and Baccharis; by lechuguilla, sotol, large-fruited yucca, narrow-leaved yucca; and by numerous species of cactuses, many small plants, and grasses.

While the plants are the most conspicuous and convenient indicators of the life zones, the native mammals, birds, and reptiles are equally characteristic. In the Carlsbad Cave region, the Lower Austral zone is characterized by the Texas jack rabbit, desert cottontail, Rio Grande striped ground-squirrel, cave mouse, gray wood rat, cotton rat, large and small kangaroo 
rats, pocket mice, lechuguilla pocket gopher, Rio Grande spotted skunk, Mearns white-backed skunk, Texas skunk, guano bat, little canyon bat, and house bat.

Some of the conspicuous Lower Austral zone birds are the road-runner, cactus woodpecker, Texas nighthawk, Cassin kingbird, white-necked raven, Scott oriole, hooded oriole, desert sparrow, painted bunting, western mockingbird, cactus wren, and plumbeous gnatcatcher.

Among the Lower Austral reptiles are the Texas diamond-back rattlesnake, leopard lizard, Texas spotted-tailed lizard, Clark scaly lizard, whip-tailed lizard, and Texas horned lizard (horntoad).

Neither plants nor animals, however, are evenly distributed in their zones, but each species is pushing and striving for its place in the sun, and its room in the soil, for its right to live and reproduce its kind. Nowhere is the struggle for existence more fierce and relentless, or adaptation and specialization carried to a higher degree, than in the desert. The slightest tilt of level that makes available a little more sunshine or a little more moisture, a dike that catches and holds a little more soil and plant food, a combination of elements of earth and soil in any way favorable to plant life, are quickly taken advantage of, not only by the strong and vigorous, but by the small and weak, in a test of power to take, and strength to hold, possession. On the other hand, the unfavorable slope that with baked surface excludes moisture, or with excess of unfavorable mineral content bars certain forms of 


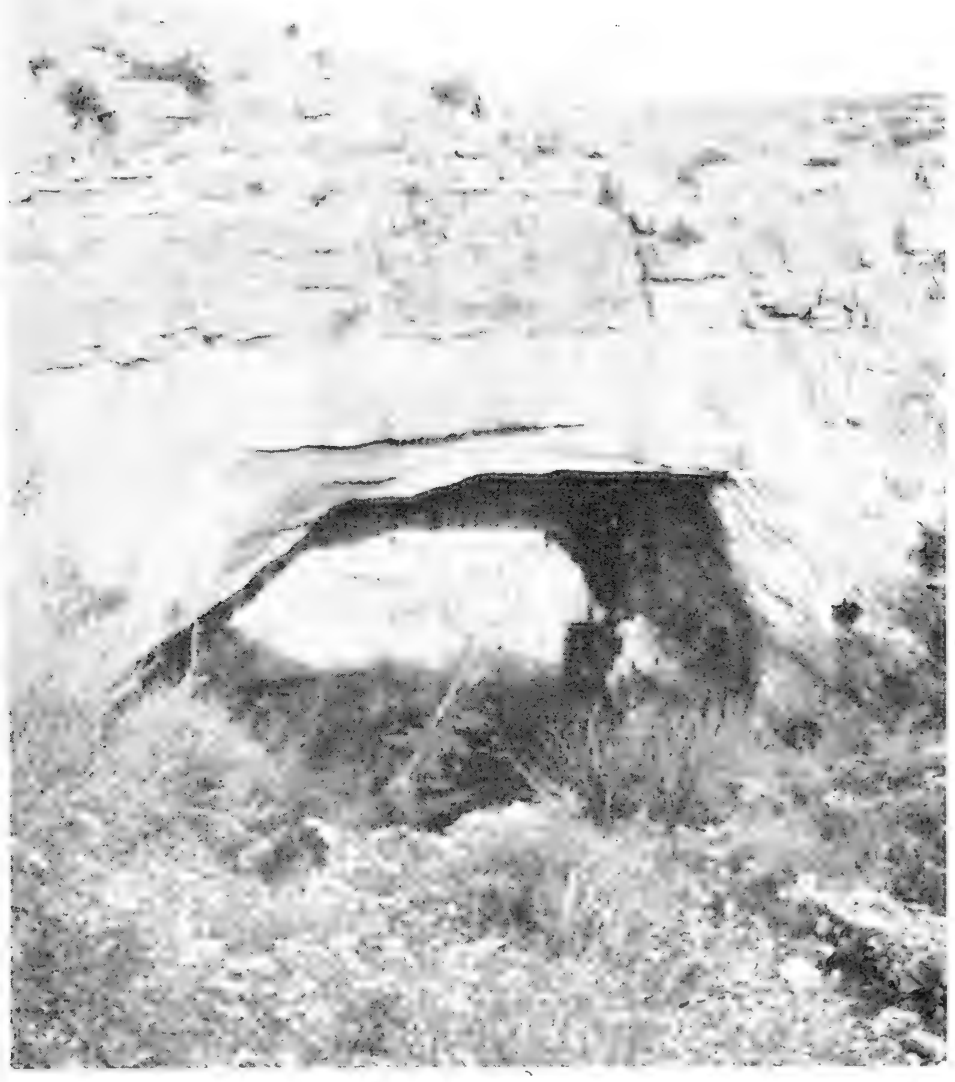

Fig. 3. West Entrance to the Carlsbad Cavern

The main entrance and exit of the bats and other animal life of the cave is pierced by a narrow shaft of sunlight during a brief interval in the afternoon. Photograph from U. S. Geological Survey. 

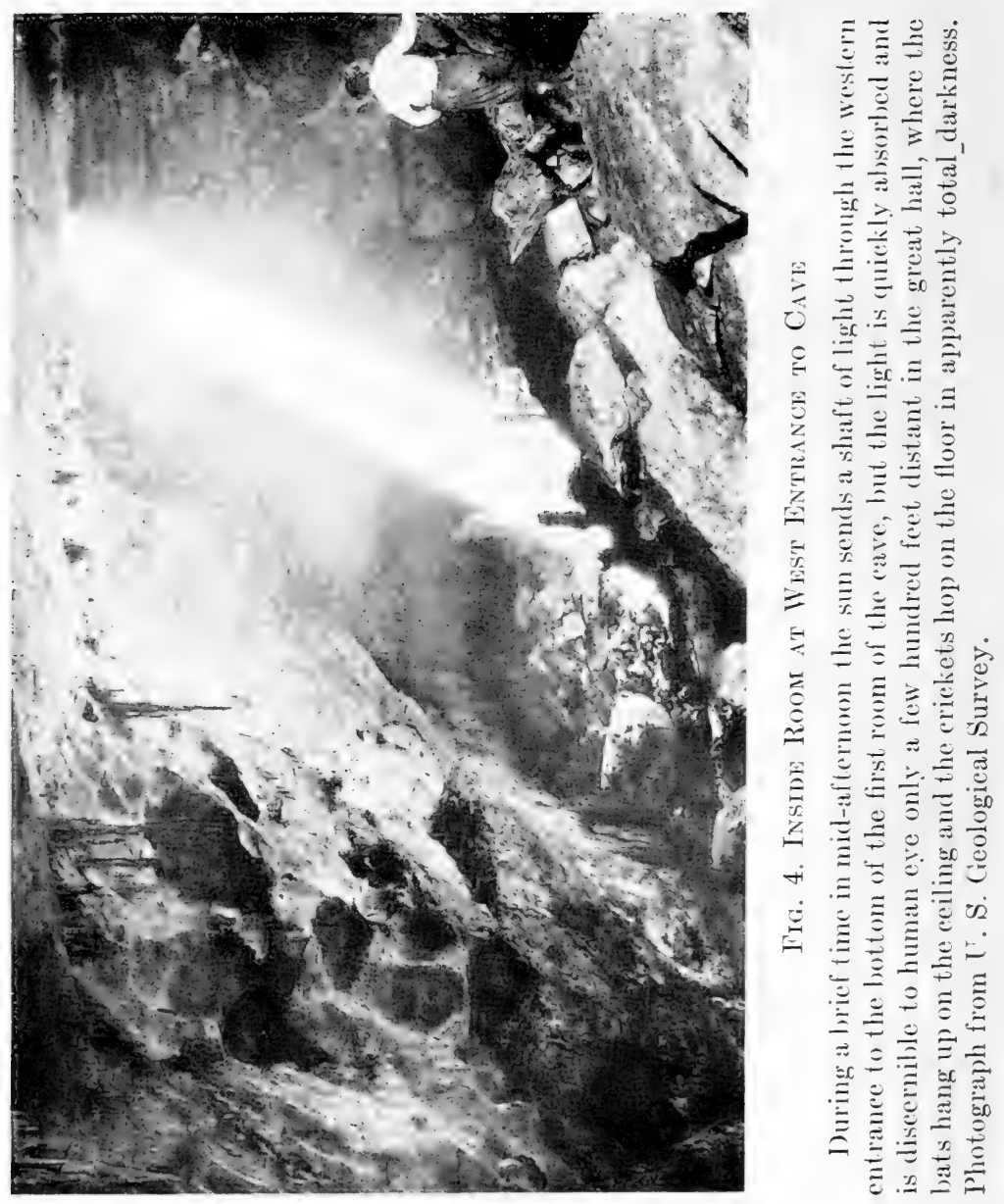
vegetation, may still afford a fair haven for a few plants that can break its crust or utilize or avoid its mineral content. Thus we have areas of infinite mixture of plants and again areas of almost pure stands, called plant associations. We may ride for miles through a golden mantle of flowering creosote bush on gravelly slopes, or fragrant fields of varnish bush on the floor of the valley, or through areas of solid tobasa grass in the path of occasionally flooded bottoms, or among the blazing torches of ocotilla on the steepest, hottest, and dryest slopes,-an endless variety of plant associations, each full of meaning and of vital significance to the student of plant ecology.

The Upper Austral zone, or its Upper Sonoran arid division, in the Carlsbad Cave region, begins at about the level of the cave entrance, or 4,500 feet on gentle south slopes, but on northerly slopes it begins as low as 4,000 feet and extends up over the high mesas and foothill ridges of the Guadalupe Mountains to 7,000 or 8,000 feet, according to slope exposure. On steeper slopes these limits are somewhat extended, and on very gentle slopes correspondingly less extreme, while such minor factors as barrenness, color and nature of soil, moisture and air currents, show slightly modifying effects on zone levels.

In the immediate vicinity of the great cave, as over much of this zone, its most striking feature is a scattered growth of scrubby juniper, striking because the unmistakable dark evergreen bunches may be seen and recognized miles away. In the rough ridge and foothill country they practically fill the zone, but are absent 
on the wide expanse of high level plains. Other characteristic woody plants are the two other junipers, nut pine, gray and Vasey shrubby oaks, mountain mahogany, small-leaved mulberry, hackberry, Apache plume, catsclaw, skunk bush, service berry, star leaf, silk tassel bush, syringa bush, manzanita, many species of rabbit brush, banana-fruited yucca, and Parry century plant.

Some of the characteristic Upper Austral species of mammals in the Carlsbad Cave region are the Texas mountain sheep, gray mule deer, rock squirrel, Rowley white-footed mouse, white-throated wood rat, gray fox, and plateau bobcat.

The conspicuous species of birds of the zone are the Mearns quail, poor-will, horned lark, raven, Woodhouse jay, pinyon jay, black-chinned sparrow, Scott sparrow, canyon towhee, and Cooper tanager.

The Upper Austral reptiles are less numerous than are those of the lower zone, but the few characteristic species include the black-tailed rattlesnake, plains rattlesnake, prairie bull snake, western collared lizard, scaly fence lizard, Poinsett scaly lizard, and desert horntoad.

The higher and less arid Transition zone, colored blue on the map, covers a limited area along the top of the Guadalupe Mountains, some fifteen miles west of the Carlsbad Cave and a larger area of the Sacramento and White Mountain plateau to the northwest. Throughout the state it generally covers the tops of the lower ranges and the middle slopes of the higher ranges from about 7,000 to 8,500 feet on northerly 
slopes and from 8,000 to 9,500 feet on southerly slopes, varying somewhat in different ranges according to steepness of slopes and elevation of base level. A high valley or plain by holding the heat of the sun's rays higher up elevates the life zones above it, while a low base level allows them to come lower down. In the Guadalupe and Sacramento mountains the general levels of the zone are about normal, but on some very steep, dry southwest slopes Transition zone species are dominant from 8,000 to 10,000 feet.

In New Mexico this zone is strongly marked by the western yellow pine, with huge scaly trünks in wide stretches of beautiful open forest, clean and grassy underneath. Douglas spruce, southern white pine, large-leaved maple, New Mexico oak and locust occupy secondary places in this forest. Extensive open parks or grassy glades appear, which along some of the stream valleys are occupied by little farms. The great value of this zone is its timber, grass, and water, its cool climate, shade and beauty in the midst of a wide expanse of low, hot plains.

The characteristic mammals are white-tailed and mule deer, two species of chipmunks, a small form of the thirteen-lined ground squirrel, the Colorado wood rat, Guadalupe meadow mouse, fulvous pocket gopher, mountain cottontail, and brown bat.

Some of the breeding birds of this zone in the Guadalupe and Sacramento mountains are the Merriam wild turkey, band-tailed pigeon, spotted owl, screech owl, hairy woodpecker, ant-eating woodpecker, red-shafted flicker, broad-tailed hummingbird, green-tailed and 
spurred towhees, mountain tanager, Audubon and Grace warblers, pygmy and Rocky Mountain nuthatches, western robin, and chestnut-backed bluebird.

Reptiles are scarce, but an occasional western garter snake is seen, or one of the short horned lizards or horntoads.

Canadian zone, shown in green on the map, covers most of the higher peaks and cold slopes of the Capitan, White, and Sacramento mountains, and a small area on top of the southern end of the Guadalupes. It is a narrow, irregular, broken area that reaches its full width only on the White Mountains. It is characterized by forests of spruce, fir, and aspens, and by many of the Rocky Mountain species of trees and shrubs.

The mammals of this restricted area included only half a century ago an abundance of the now extinct Merriam elk, and still include the White Mountain spruce squirrel, Rocky Mountain meadow mouse, two species of little shrews, and undoubtedly the hoary and silver-haired bats.

The breeding birds of the zone in this area are the olive-sided flycatcher, long-crested jay, crossbills, pine siskins, white-crowned sparrows, gray-headed junco, Rocky Mountain creeper, red-breasted nuthatch, golden- and ruby-crowned kinglets, and Audubon hermit thrush.

Hudsonian zone shows but a trace on the top and upper cold slope of Sierra Blanca, or White Mountain Peak, at the northern end of the Sacramento Range, which reaches 11,880 feet elevation. This timberline 
zone is indicated by a few dwarfed Engelmann spruce that reach up within about two hundred feet of the top, and by many dwarf plants of the zone, such as Silene, Arenaria, Saxifraga, Rhodiola, Sedum, Orthocarpus, Erigeron, and Ligusticum. The whole southerly slope of the peak is bald and grassy, while the northerly slope is steep and rocky, and the narrow crests of two lateral ridges give scant foothold for other than dwarf plants and have little attraction to the birds and mammals of this zone. Still in one brief visit to the peak I noted Clark nutcracker, Townsend solitaire, and the pipit, probably mere visitors from the extensive areas of the zone in the mountains of northern New Mexico. 


\section{CHAPTER 3}

\section{Conspicuous Vegetation of the Region}

\section{TREES}

To the tourist and the casual observer the country about the Carlsbad Cavern might well seem treeless, for one can sweep the circle of the horizon without recognizing a tree head-high. The yuccas and sotols are generally the tallest forms of vegetation in sight above the rims of the canyons, unless with a field glass one picks out the yellow pines on the Guadalupe Mountains, or the slender lines of cottonwoods along the Pecos and Black River valleys. The Guadalupe and Sacramento mountains are more or less covered with cool, dark evergreen forests. The desert cottonwoods, tall and spreading, as they grow at Washington's ranch on the banks of Black River might well inspire the soul of an artist. Admitting these as real trees, let us follow the rocky trail over the ridge to Oak Springs, from which the patient burro brings daily loads of water to the cave workers, for along the cool slope of the deep little canyon the April air is rich with fragrance of the Mexican madrones, with their polished red boles, large evergreen leaves, and masses of tiny bell-shaped flowers. They belong higher up in the mountains, but come down on cold canyon slopes even below the level of the cave opening as round-topped trees twenty to forty feet high.

Several species of oaks, mainly the chestnut oak, 
attain the size of small trees in Oak Spring and other canyons where, well sheltered from sweeping winds, their crops of acorns have supplied food to man and beast for untold time. Scrub oaks of several species, rarely attaining the dignity of trees, cover many of the more exposed slopes and still have a real value as food and cover for stock and game.

Fair-sized black cherry trees grow along the canyon bottoms and bear an abundance of sweet fruit for birds and beasts. Even man enjoys their juicy richness, with its faintly bitter tang.

In many of the gulches and canyons New Mexico maple forms groves of small trees, affording grateful shade, tough, hard wood, and a possible source of sweet sap.

A small green ash often grows with the maples and oaks and adds another source of tough, springy wood in a country where such wood fiber is scarce and needed.

The little desert black walnut, low and spreading, may easily be overlooked in the dry washes, but on rich bottom land, where moisture is not too scant, it sometimes makes trees fifteen or twenty feet high, with trunks of fence-post size. Its feathery foliage might almost be mistaken for that of the mesquite, but its little, round black walnuts, the size of marbles, often load the branches and are unmistakable. They are as palatable as any walnuts if one has time to crack and eat them. Once when a heavy shower kept me waiting for half an hour under the camp wagon beside one of these trees, I decided that I could live on walnuts if I gave all my time to it. The rock squirrels and wood 
rats get most of the nuts, but other rodents take a part of each year's crop.

Hackberries are here more often bushes than trees, but in the canyons some grow to respectable size. Both large and small trees are often loaded with tiny, sweetcoated nutlets, greatly enjoyed by rodents and birds, and when well pulverized, shells and all, make a rich, sugary loaf of nut-bread.

Native mulberries reach small tree proportions in moist and fertile canyons, but in the open are mere bushes.

The Mexican buckeye, growing in the canyons, and especially in the mouths of the large caves, is either a small tree or large shrub, bearing dense sprays of beautiful pink flowers in early April.

The scrubby little junipers which form a conspicuous part of the vegetation of the hillsides, in wide bunches four to six feet high, are kept down by wood cutters and seekers for fence posts, and by browsing goats, so they rarely attain tree size. They yield bushels of sweet berries eagerly sought by goats, as well as by coyotes, foxes, and a host of other hungry mammals and birds. They furnish the dominant evergreen cover of the rugged limestone ridges and have a value far beyond that indicated by their humble appearance.

A few small trees of the silky-leaved mountain juniper are found over the ridges a little higher up, and the beautiful blue-leaved, round-topped, checker-barked juniper reaches down almost to the cave.

The little nut pines or pinyon trees show along the crest of the next higher ridge west of the cavern, and 


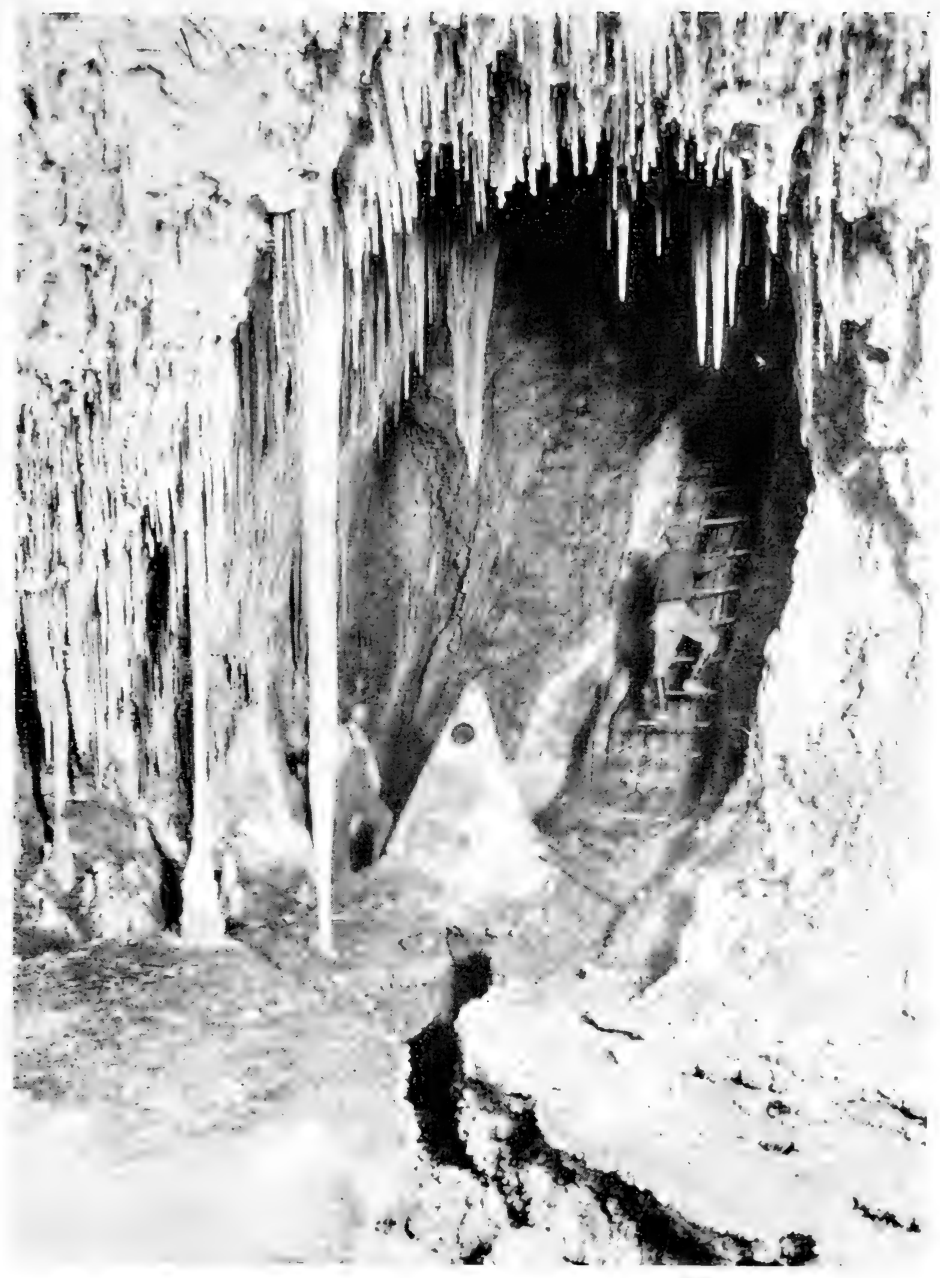

Fig. 5. The Floor of the Lowest Roon in the Cave

Here at the bottom of the swinging wire ladder, some seven hundred feet below the surface of the ground, old skeletons and mummies of bats were found, and also tracks of the cave mouse, and tracks and bones of the ring-tail. Photograph from L.S. Geological Survey. 


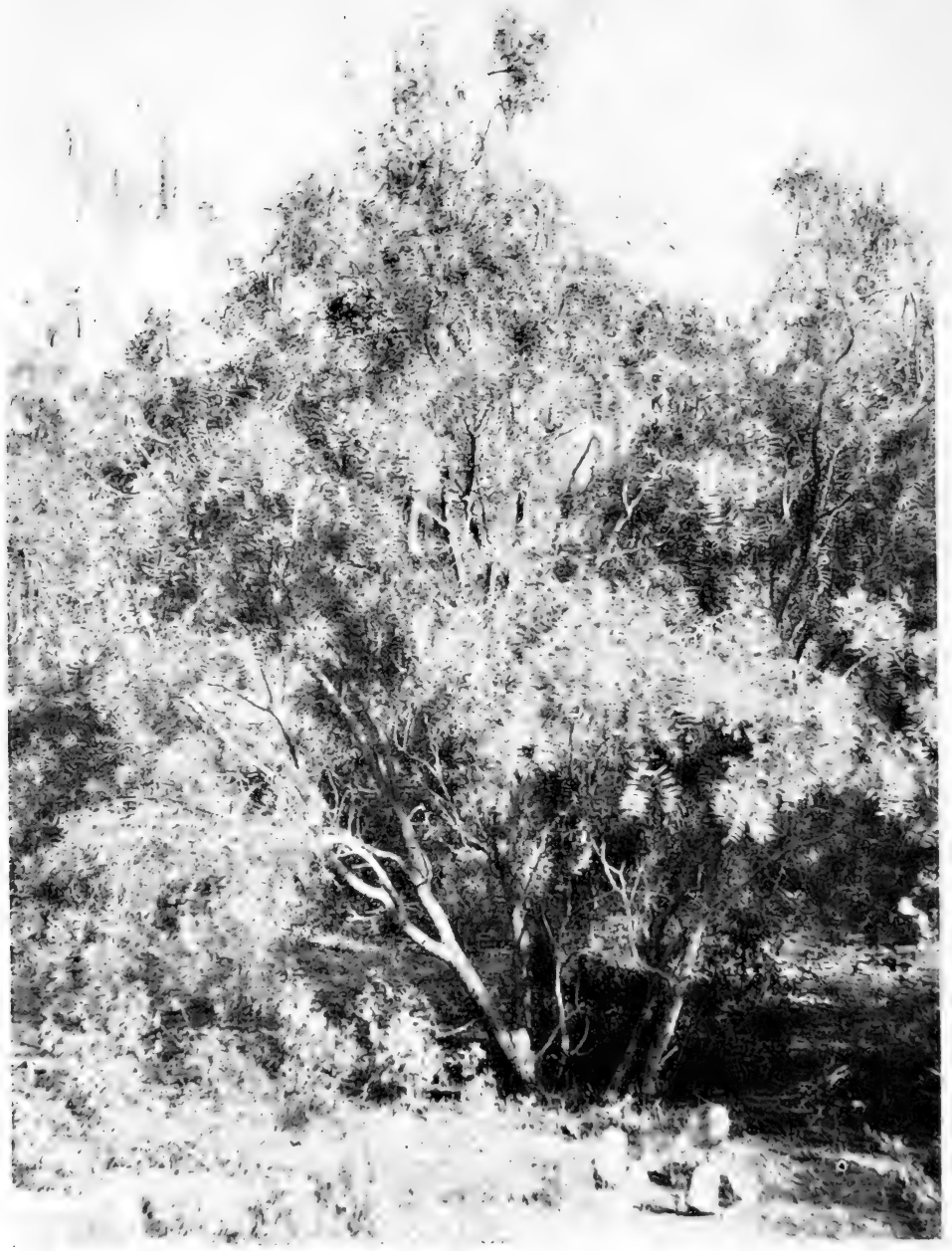

Fig. 6. The Mesquite Tree (Prosopis glandulosa) Fult of Fruit

A tree like this will yield a bushel of long bean pods, almost as sweet as sugar, a valuable stock food, and once an important food for man and many other of the native animals. 
one old tree of unusual height stands against the north face of a cliff in the canyon about two miles below the cave entrance. An hour's walk up the canyon would have taken the Indians to plenty of these bountiful nut-bearers, the sweet and delicious nuts of which furnished an important part of their winter's food.

Two small yellow pines in the mouth of Slaughter Canyon have grown from seeds that drifted down from the head of the canyon and here, two zones below their real habitat, are conspicuous among the sotols, lechuguillas, and other Lower Sonoran plants. Many tall trees are seen against the sky line at the head of the canyon and beautiful groves of large trees are found just over the main ridge of the mountains.

The mesquite (Fig. 6), although generally considered a tree, here on the dry plains grows mostly underground, sending up branches from two to eight feet high; but occasionally in the bottom of a gulch, where its long roots can reach water, it develops into a real, though small, tree with spreading top, its feathery foliage, like delicate green ostrich plumes, reminding one of the pepper trees along California sidewalks. After a rain its yellow catkins burst out into fragrant bloom and a little later long, mottled bean pods hang from the branches, becoming sweet and sugary when ripe, and yielding a rich food for stock. In former days they formed also an important food for many southern tribes of Indians. The little hard, smooth beans, embedded in thick pods, when swallowed by stock are neither broken nor digested, and so are widely sown over the grazing areas. 
In Garden Canyon just over the ridge from the big cave, as in many canyons higher toward the mountains, grow the New Mexico locust trees, similar to the fragrant eastern locust, but with delicate pink instead of pure white racemes of fragrant flowers; a wonderful flowering tree that should be more widely under cultivation.

\section{SHRUBBY VEGETATION}

In the rigorous climate of arid regions with reduced rainfall and rapid evaporation, extremes of summer heat and sudden changes to severe cold, where the half-naked soils are deprived of the mellowing effects of winter snows, and often are exposed to severe winds that beat the branches and tug at the stems of such hardy plants as are able to withstand the fierce onslaught, it is not strange that the vegetation should take on weird forms. To such plants as persist through it all come long mild days of clear sunlight, and after occasional showers, moist balmy nights, and days of intense growing activity, the desert blooms in wonderful beauty. Under no other conditions are the survival of the fittest or the elimination of the unfit more marked than in these arid regions of great extremes, where forests are replaced by low shrubs and every plant is protected by some form of armor, or has means of defense against destruction. Naturally, under such adverse conditions, strange types of vegetation have developed. Some are highly modified forms of common and widespread groups from the north or south. Others are of restricted range and are not found beyond the limits of the semidesert region. Each 
has its own type of adaptation, and each plant its own history, and its ancestry, and its struggle, that if fully recorded, would make a fascinating story.

One of the most typical of desert plants, the ocotilla or Devil's walking sick (Fouquieria splendens), grows in great abundance over the hot, rocky slopes near the Carlsbad Cave, and stands for most of the year without leaves or flowers, a mere cluster of dry spiny poles rising from a single base to a height of eight or ten feet. In early May, if there has been a recent rain, it sends out a dense coat of small green leaves about as long as the thorns, and a little later, long spikes of brilliant red flowers from the tip of each stem. For a brief time these flaming banners give color to the hillsides, and the nectar-laden flowers are the chief attraction for many insects, hummingbirds, orioles, and other birds of insectivorous and nectar-eating habits. Soon the seeds have ripened, the leaves have dropped off, and the naked spiny poles stand for eleven months or longer, waiting another springtime or another rain.

Over the dryest mesas of the Pecos Valley and extending up on the hot slopes of the ridges to the level of the great cave the creosote bush, with distinctively flat-topped, triangular form, and dark, evergreen leaves, is always a striking feature. Without thorns, its soft branches and green leaves would seem to offer tempting forage for all browsing beasts, but a thin varnish rich in creosote, covering the leaves and twigs, renders it not only inedible but immune to evaporation and the effects of long, hot periods of drought. In May, if there has been a recent rain, these bushes burst forth 
in great bouquets of buttercup-like flowers, often spreading a golden robe for miles over the valley country and filling the air with a pungent fragrance, not from the flowers so much as from the fresh varnish on the young leaves and twigs.

The bean family (Leguminosae) is represented by such desert trees as the mesquite, but more abundantly by numerous desert shrubs, one of the commonest of which is the slender Acacia constricta, with delicate, compound leaves, and straight, slender spines. In flowering time it is covered with little golden balls of stamens and later the slender mottled bean pods dangle in profusion. For most of the year its naked branches and keen pointed thorns stand repellent and apparently lifeless.

Another common little bean bush with small, compound leaves and fragrant pink flowers will be recognized as the catsclaw (Mimosa biuncifera) as soon as one comes in contact with it and has to back out painfully to escape the numerous pairs of stout hooks which protect its branches. This is the most vicious of the several spiny bean bushes of the region, and well immune to the attacks of hungry ruminants.

A large evergreen and spineless shrub of the same family is the goat bean, or coral bean bush, found along the canyons and cliffs and in the mouths of caves. In April it sends out great bunches of dark blue, wisterialike flowers among the dark green leaves, and later thick bulging pods of large coral-red beans, which have the reputation of being poisonous to goats if masticated when eaten. When swallowed whole, as they generally 
are, they pass through without injury to either bean or goat and are thus scattered in many fertile spots along the cliffs. This fact explains the abundance of the bean bushes in the mouths of caves, where the goats commonly take refuge from the storms.

One of the numerous bean bushes, or shrubby legumes, is the beautiful little Dalea, or Parosela formosa, protected, not by thorns, but by numerous glands of a rank-smelling secretion as effective as the musk of a skunk. Even the goats do not eat it. In April it fairly glows with tufts of small, rich purple and yellow flowers set in a mass of silvery filaments, a combination that tempts one to examine closely and admire enthusiastically.

Allthorn, crown of thorns or crucifixion plant, next to cactus the spiniest thing on the desert, grows as a dense shrub over the valley and on warm slopes of the ridges up to and above the cave. Its leafless, greenbarked branches and stout thorns defy man and beast, except for the cactus wrens, thrashers, and wood rats, which have made a truce with its dagger points and claim its protection for nests and houses. Its inconspicuous, little white flowers and black berries come only when there is enough rain to produce them, and for most of the year the naked thorns and stems stand at arms.

Another leafless plant of the desert is the so-called popotillo, joint fir, or Mormon tea, a low graceful shrub of slender green branches, rush-like in appearance, the green bark of the stems functioning in place of leaves. As it has no spines, or only mildly spinescent tips, to its 
branches, it is generally eaten down to stumps by goats, cattle, and horses, and perfect plants are found only in arid wastes or on inaccessible cliffs.

The trifoliate barberry, or algireta of the Mexicans, with its viciously spiny, three-pointed, and rigid evergreen leaves, abundant large yellow and honey-scented flowers, is one of the very successful shrubs of the desert, resisting all enemies and bearing an abundance of delicious berries, tart and refreshing when well ripened. To the white people they suggest cranberries and are used for jellies, but by the Indians they were probably eaten either fresh or dried, as in camp we have found them in either form very acceptable.

The blue-thorn ( $Z i$ yphus lycioides) is a dense shrub as high as one's head, growing singly or in clusters, with small leaves on the branches and thorns and with inconspicuous flowers and little blue berries. Almost as spiny as the allthorn, it is one of the well armed desert plants that can not be eaten or injured, and offers its spiny protection to many less fortunate plants as well as to birds and mammals.

The sumacs of some three or four species are able to exist without thorns or active poisons, for they exude gums of rank odor and taste that evidently help to keep browsing animals at a respectful distance. Still in times of scarcity of other food they are sometimes eaten, and the berries are the food of many birds and small mammals. The small-leaved sumac grows to be a large dense shrub, abundant in many places. The evergreen sumac is recognized by its large green leaves, and the skunk bush, with its trifoliate leaves, is a low 
shrub of the canyons and ridges. Its pliant stems are generally used by the Indians for making baskets.

The wild syringa, or a small-leaved form of it, is common along the canyon walls and up into the mountains, its large, white, four-petaled flowers being as fragrant as those of the cultivated variety which grows in dooryards both in the east and west. In some of the open caves it crowds back well into the doorways, where its flowers show beautifully white against the black background.

The star leaf, Choysia dumosa, a rare desert shrub of the low mountains and foothills, is a dense little evergreen bush that one examines closely to see if it can be a fern or club moss until its fragrant, apple-blossom flowers are discovered, bedded thickly in dark green leaves. It grows abundantly along the cold canyon walls two miles below the great cave entrance, and still more abundantly on the cool slopes of Slaughter Canyon and well back into the doorway of the Bighorn Cave. Its beauty, fragrance, and rarity would seem to render it worthy of cultivation, but best of all is the thrill of its discovery in the wild remote places in which it has made its home.

The desert willow (Chilopis linearis), not related to the willows but with some resemblance to them in its slender stems, narrow leaves, and its habit of growing along the bottoms of dry washes, really belongs to the Bignonia or trumpet-creeper family, as is readily seen from its large, white trumpèt flowers and the long slender pods and winged seeds. It grows to be a large shrub and is generally abundant along the bottoms of 
canyons and gulches, where it is conspicuous by reason of its graceful form, beautiful flowers, and light-colored spineless branches. Unarmed and seemingly unprotected, it is not generally eaten by stock and evidently proves unpalatable or unwholesome.

The gray shadscale (Atriplex canescens) would be an abundant shrub over the desert if armed as fully as many more fortunate plants. With fleshy, edible leaves and twigs and no real spines for protection, it leads a precarious existence and is crowded to nooks and corners on the cliffs and along the sides of steep banks, or hides under the wings of some thorny shrubs or cactuses where a few plants can mature their fourwinged seeds and keep the species alive. No small part of the value of thorny plants is their protection of such weaker neighbors.

The well known grease-brush (Sarcobatus vermiculatus) thrives where the soil is so impregnated with soda, gypsum, lime, and salt, that few other plants can compete with it. On many of the "alkali" flats it is the dominant shrub, growing in a clear stand over extensive areas, its light green and fleshy leaves testifying to ample moisture and rich plant food. The leaves and twigs, although strongly flavored with salt and soda, are eaten by stock while fresh and green, but the myriad twigs quickly harden into stout thorns that protect the plants from complete destruction.

The cliff rose, poniel, or Apache plume (Fallugia paradoxa), with large, white flowers and powder puffs of plumy seeds, is thornless and edible, and is so extensively eaten by stock that few plants remain in the cave 
region except on cliffs and ledges inaccessible to ruminants. In less arid regions where there is always an abundance of grass this shrub is little eaten; but in the open arid region, well stocked with cattle, sheep, or goats, it soon disappears.

The yucca family is well represented in the cave region by three species of yuccas, or Spanish bayonets, and by sotol and bear grass. Most conspicuous and largest of the Spanish bayonets is Yucca macrocarpa, often twenty or twenty-five feet high, and with a trunk a foot in diameter inside of its rough clothing of decurved, rigid and sharp-pointed dead leaves. The green leaves stand erect or slightly spreading near the top, guarding with a circle of bayonets the great spike of lilies that crown the stem and later the banana-like fruit cluster of fleshy, edible pods or capsules inclosing the myriads of flattened black seeds. The plants are so heavily armed that only while young are their flowers and fruit in danger from goats, cattle, and horses. When above the reach of such enemies, they survive for many years, beautifying the desert, scattering their seeds, and offering armed protection to nesting ravens, orioles, and crimson finches. Even the woodpeckers burrow into their trunks and white-footed mice and timid lizards hide among their dead leaves.

The slender-leaved Yucca radiosa (Fig. 7) out on the flats also grows almost to tree size, the tall flower stems often reaching six or eight feet above the ten or twelvefoot summit of the leafy trunk, and bearing great spikes of waxy white lilies and later dry capsules full of innumerable flat, black seeds. While slender and not 
very rigid, the leaves are so sharp-pointed as to afford good protection to nesting birds,- - white-necked ravens, orioles, thrashers, cactus wrens, and many others. Fortunately the plant is not edible and, since the days when Indians used its leaves for baskets and its roots for soap, is rarely injured by men or animals.

A low, trunkless form grows on the east side of the Pecos River and over the Staked Plains, just as a smaller form of Yucca macrocarpa grows over the higher ridges of the Guadalupe Mountains.

The sotol (Dasylirion leiophyllum) (Fig. 9) is one of the most graceful and picturesque plants of the desert, with its rounded mass of basal leaves, growing often in hourglass form with spreading evergreen leaves above and drooping, old, yellow leaves below, and with its tall flower stalk bearing a graceful wand of small creamy flowers rising fifteen or twenty feet higher. Like many desert plants, it grows long and slowly, storing up plant food for many years until it can make its primal effort of blossoming and fruiting without regard to the rains. Sometimes this effort so exhausts it that it dies, but generally it lives to store another reserve of food, and to blossom again and again. In places it is the dominant plant over miles of arid, rocky slopes. Heavily armed with stout recurved hooks along the margins of the ribbon-like leaves, which effectively protect its rich store of food from grazing animals, it is often used by the ranchmen as a rescue food for starving stock in times of drought, the stems being split by broad cleavers so the cattle can eat out the crisp rich hearts. To the Indians it was also a 


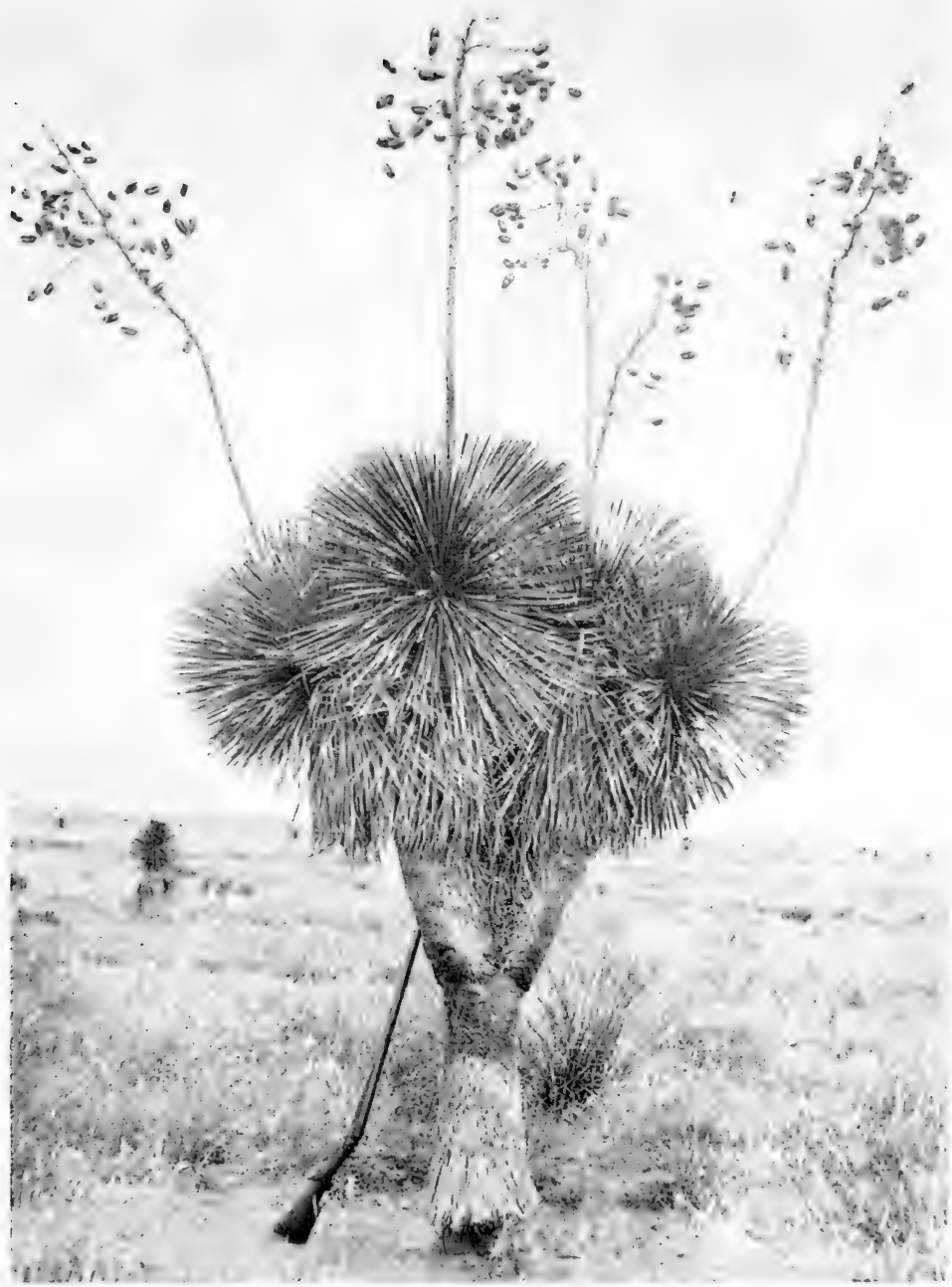

Fig. 7. The Narrow-leaved Yucca (Yucca radiosa) IN Fruit

Mockingbirds, thrashers, and cactus wrens build their nests among the needle-pointed leaves of these yuccas and raise their young in safety, taking advantage of the armed neutrality of the desert. 
regular food, probably both cooked and raw, as charred old leaves are found in the kitchen middens of their caves. The tender bases of the tip leaves eaten raw are much like celery hearts.

The mescal (Fig. 8), or little century plant, the lechuguilla of the Mexicans, was to the Indians the most important plant of the region, and it is still abundant and able to hold its own against all enemies. It is doubly armed with keen, rigid spikes on the tip of every dagger leaf, and savage hooks grow along both edges of the blades as if to help it to spear and hold its prey. It is so carefully avoided by man and beast that there seems to be no checks on its abundance except its own choice of situation, the shallow soil of the arid limestone ridges, the glaring heat of the desert sun, and a minimum annual rainfall. For it, time has no value, for it grows when there is a shower, and rests until there is another, storing and protecting its energy for many years, not for a full hundred years, but possibly sometimes for a quarter or a half of a century, before venturing to send up its great stem to blossom and bear fruit, and then to die and scatter its myriad seeds. Just before blossoming time, when bulging with its rich store of accumulated plant food, the mescal was formerly gathered, roasted, and eaten by the Indians as their most important food. Now it seems to cumber the ground, but it is useful in protecting enough of the grasses and forage plants to provide seed to keep the over-stocked ranges from being completely denuded.

Numerous genera and species of cactus, from the heavily spined Devil's head to the slender, branching 
cane cactus, the thousand-headed cliff cactus, the broad-bladed prickly pear, and numerous little pincushion kinds, form conspicuous features of the desert flora. Their wonderful flowers of bright crimson, deep magenta, scarlet, orange, or yellow give brilliant touches of color, and the ripe fruit of many species is extensively eaten by native birds and mammals while several kinds are relished by man. For storing plant food and moisture and then waiting for another rain, no matter how long, and patiently hoarding for the time of flowering and fruiting, few plants can equal the cactus in its perfect adaptation to desert conditions. Most of the species are juicy and nutritious and would be eaten by every hungry and thirsty creature, but for the armor of keen spines. Their moisture would also be quickly lost by evaporation but for the impervious covering of cellulose, which all but prevents evaporation. Thus armed and equipped they are fitted for desert life as are few other plants. 


\section{CHAPTER 4}

Animals and Plants of the Region in Relation to the Aborigines

The Carlsbad Cavern was once the center of a large Indian population, as is shown by dozens of mescal pits (Fig. 11) in the immediate vicinity, five of these being at the very mouth of the largest entrance to the cave; also by grinding-holes (Figs. 13 and 14) at the entrance, by flint chips, broken arrow points, and bits of pottery scattered over the ridges, by bones in burial holes in the mouth of the cave, and by human skeletons buried in the deep guano deposits, far back in the cave. Undoubtedly the Indians used the great sheltering dome of the entrance, where a hundred or more individuals could cook and sleep in the warm cave air, completely protected from storms and out of danger from enemies. That they had free entrance to the great rooms of the cave, either along narrow shelves of rock, or by ropes or ladders, ismore than probable, but any extensive occupation of the dark chambers would have left more evident traces. Apparently the throat of the cave was their main retreat for shelter, comfort, defense, and burial.

However barren and inhospitable the surrounding country may appear to the general observer, it was a region of abundance and even luxury to the aborigines. The climate was mild, and with the protection from winter storms and winds afforded by the cave, the inhabitants needed little in the way of houses or cloth- 
ing. Timber was scarce, but excellent fire wood in the form of dry cactuses, bushes, sotol and yucca stems was abundant and easily obtained without the trouble of cutting. On the high, half-naked, limestone ridges, rocks and stones were found for shelters and fireplaces, and an abundance of buffaloes, elk, and deer furnished skins for such clothing as was required.

Food, always the main factor in animal economy, was abundant and easily obtained before the destroying white man came. Large game was to be found on all sides. If the herds of buffaloes did not come up on these stony ridges, they occupied the valley below, where they could be watched for twenty miles as they came down to the Pecos or Black rivers for water, through deep cut trails that gave to the hunters, armed with bows and arrows, every advantage of close range and easy selection of choice animals. This alone would have insured a happy Indian existence. But other game was also abundant. Gray mule deer still roam over the rocky ridges and hide in the narrow gulches. Antelopes, now almost gone, occurred then in great herds over the valley. Mountain sheep climbed over the high canyon walls, as they do today only ten miles to the west of the cave. The Merriam elk were then abundant only a day's journey in the Sacramento Mountains. Bears and wild turkeys were within easy reach in the gulches to the west, and probably came to the very door of the cave, but these animals were sacred to some of the southwestern Indian tribes and were not used as food. Small game was also abundant and easily procured. Jack rabbits, which today com- 

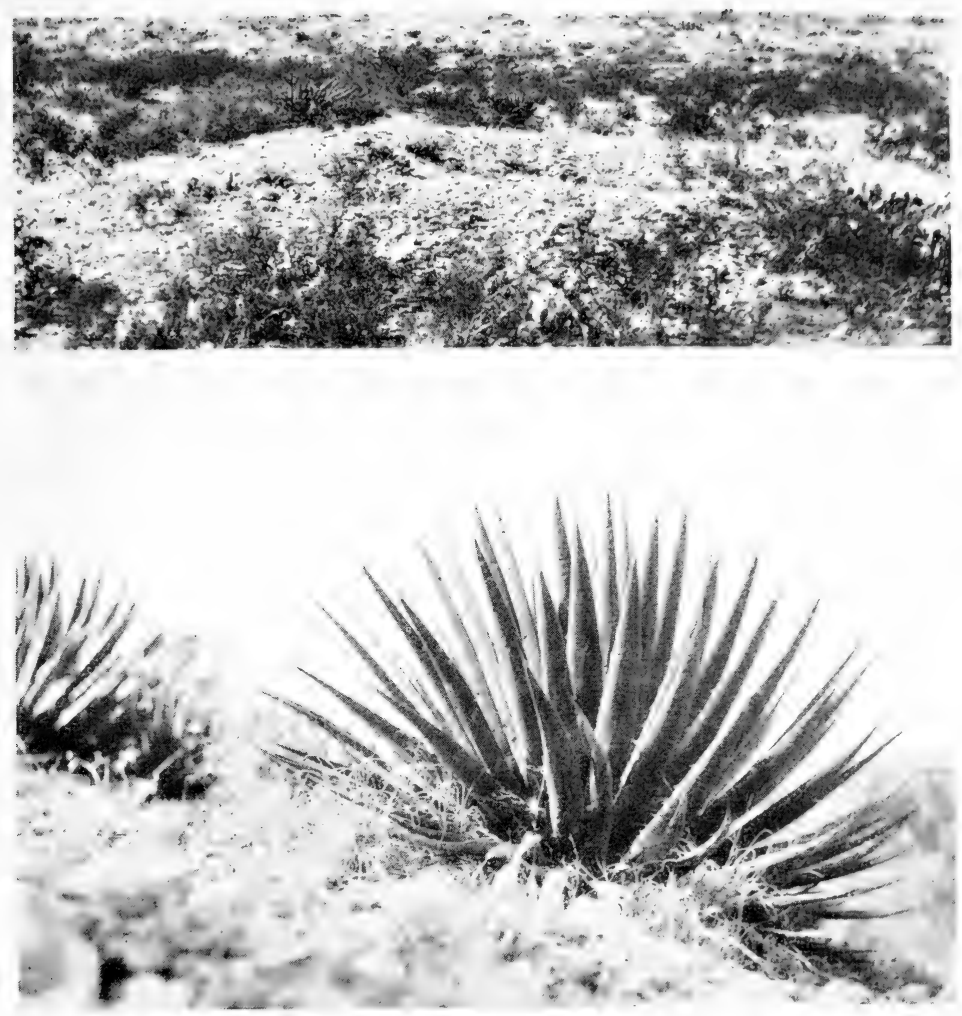

Upper: Fig. 11. Old Mescal Pit Where the Indians Roasted Agaves

The stones were thrown back in a circle when the mound of roasted mescal was last uncovered, perhaps one hundred or many hundreds of years ago.

Lower: Fig. 12. A Single Well Developed Mescal or Agate Plant Fit for Roasting

With a mass of rich food stored in its central core, protected by the rigid spikes and vicious hooked teeth of the leaf blades. 

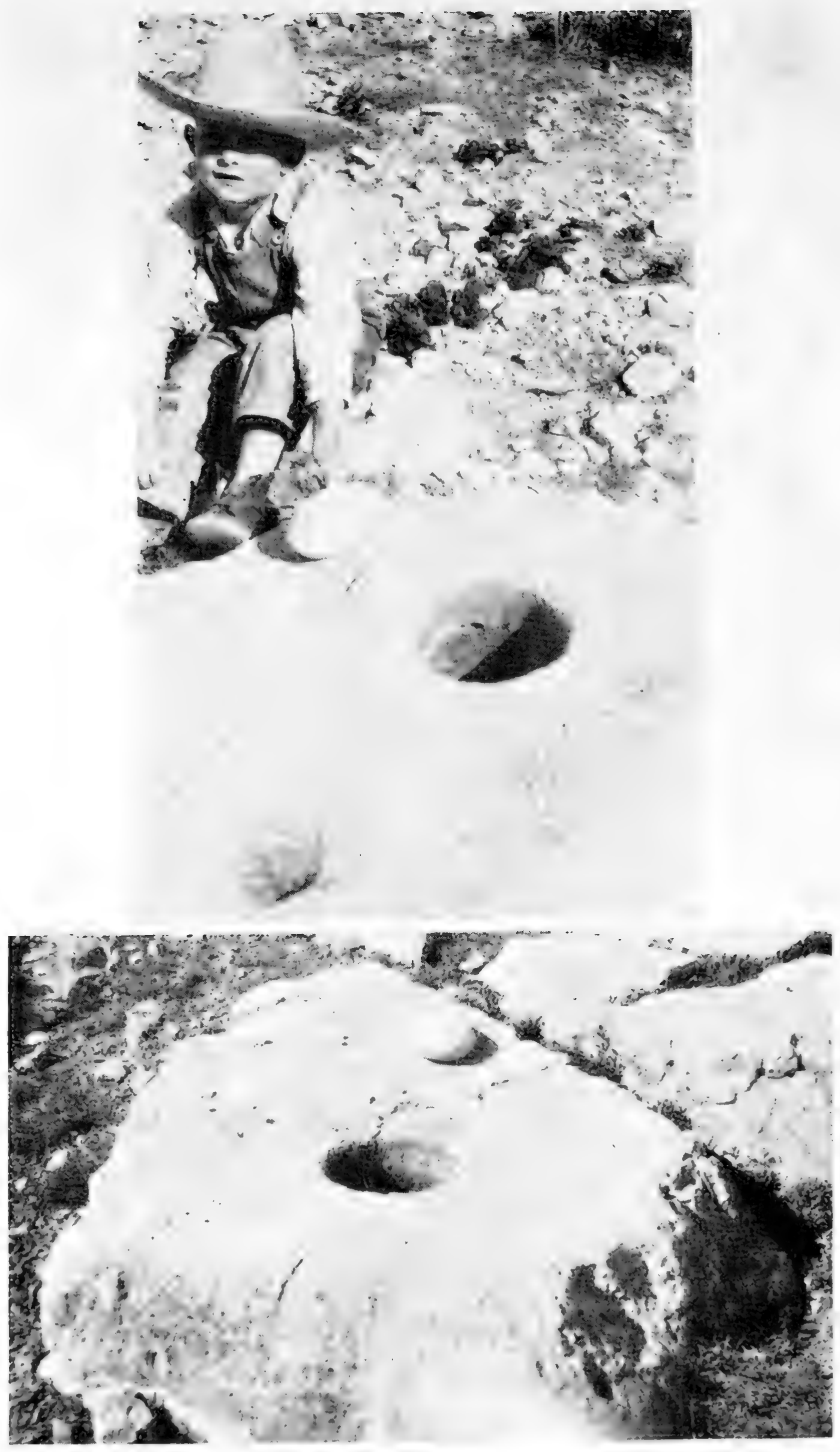

Figs. 13 and 14. Old Ixdian Grinding-holes Just in Front of the Carlsbad Cavern

Here the acorns, mesquite beans, and many of the native seeds were reduced to meal or flour for food. 
prise the principal wild life to be seen in the valley, were then tame enough for good hunting with bows and arrows. Cottontails are still abundant in the valleys and on the ridges, while fat rock squirrels occupy the canyon walls and are easily caught in dead falls made of flat stones tilted up on a notched stick. Populous prairie-dog towns are still found at the base of the hills, and their fat little occupants are easily obtained. But most abundant, most easily obtained, and most delicious of all the small game are the two species of wood rats (Neotoma micropus and N. albigula) that live in the cliffs and cracks of the rocks, even far down the throat of the cave, and make their houses of sticks, stones, and thorns under cactus, mesquite, and all thorn bushes, and in the dagger-bristling bunches of yuccas or lechuguillas. Anyone who could not go out with a long stick and catch a meal of wood rats before supper would not be much of a hunter. Kangaroo rats, pocket gophers, and ground squirrels were always available, but probably were rarely needed for food.

Scaled quail (cotton-tops) were, and still are, abundant and easily trapped or shot at the water holes, and the beautiful speckled Mearns or fool quail, so tame as to be easily killed with a stick, are still found on the ridges above the cave.

A few years ago great numbers of geese, ducks, coots, cranes, herons, and other water birds and waders wintered along the Pecos, and considerable numbers still do, while big catfish, hard and soft-shelled turtles, and heavy-shelled mussels gave a good variety of game fully appreciated by the aborigines, if the old camp- 
fire stones, flint chips, bits of bone, and clam shells uncovered among the sand dunes along the river banks, can be accepted as evidence.

The Mexican beaver and the Pecos muskrat found in the Pecos and Black rivers doubtless furnished both food and warm clothing, as may also have done to some extent the raccoon, the ring-tail, the gray fox, the bobcat, the coyote, and three genera of skunks; so with buffalo skins for moccasins and tepees, and with buckskin, antelope, and mountain sheep skins for general clothing, there was no lack of dress material.

Important as was the animal food to a primitive people, the plant food was no less so. Of edible, uncultivated plants, few regions could be more bountiful. First and foremost in inexhaustible abundance over hundreds of square miles of rocky ridges grows to this day the little mescal, the lechuguilla of the Mexicans, a small century plant, or agave, with spiked and jagged leaves clustered around a large heart stored with choicest plant food, intended to produce a tall stalk of nectarladen flowers and a million seeds as the crowning effort of the plant before dying and shriveling away to make room for its progeny. Just before this final triumph of its many years of growth and storage, the storehouse being full to bursting with rich food, the mescal head was gathered by the Indians, and with dozens of other similar heads was thrown into a dying bonfire of coals and ashes, which was then buried under a pyramid of small stones. Dry wood was then piled over this and set on fire and the mescal heads were left to cook for a couple of days and nights. The half-cooled mound 
was then opened, the stones thrown back in a wide, craterlike rim, and the well cooked heads carefully removed and opened. The rich food was taken out and eaten, or was placed in baskets or spread out on clean stones to dry in great slabs that would keep for months.

Years ago Gen. H. C. Merriam, who had trailed bands of raiding Apaches, described to me the freshly opened mescal pits with their delicious food somewhat like candied sweet potatoes, and told of long swift journeys made by the Indians, each with a slab of dried mescal tied to his saddle.

With mescal, and perhaps sotol (pronounced soto) as vegetables, it is probable that these Indians did not cultivate squashes, melons, corn, and beans as extensively as did the Pueblo tribes farther west. For nut bread they had an abundance of acorns from three or more species of oaks growing in the gulches, and from other species a little higher up in the Guadalupe Mountains. Four well worn grinding-holes at the entrance to the cave were probably used for grinding acorns, but may have been also used for crushing the sugary pods of mesquite beans, of which the Indians make a sweet and very nutritious cake. The valuable, foodproducing mesquite bush covers practically the whole Pecos Valley and the warm slopes of the ridges to above the cave. The little black walnuts grow in great profusion in the wider gulches, the nuts of which although delicious are so small that one must work half the day to get a good meal from them. Wild onions, wild potatoes, and other bulb and tuber-bearing plants are still found here. The seeds of grasses and of a great 
variety of plants may have furnished the Indians with flour and meal, but to what extent they were used, or what kinds were used, will never be known, as many of the native plants have disappeared as completely as have the original inhabitants of the cave country.

For fruits there are an abundance of petaya, the most juicy and delicious of all the cactus fruits, the purple figs of the prickly pear, the tart scarlet berries of the Mammillaria cactus, wild cherries and grapes in the canyons, and the algireta or spiny-leaved Berberis trifoliata, the best of all the barberries. A little higher in the mountains wild currants, gooseberries, service berries, and manzanita berries are to be found. Hackberry trees are abundant in the canyons, and their rich meats with a sweet coating make a palatable cake when the thin shells are well pulverized. Whether or not these nuts were used as food by the Indians, however, is not known. Sweetness was not generously provided by nature in this land of abundance, but the little New Mexico maple, common in the canyons, may have supplied a limited quantity of syrup or sugar.

These mere hints of the native food supply may well have left out many of the best and most important sources, but they are sufficient to indicate a land of plenty containing many of the comforts of wild life. Even some of the luxuries were not omitted, for wild tobacco still grows along the hot slopes of the canyons and more abundantly along the sandy banks of the Pecos, while two or three species of wild tea, Ceanothus, grow near enough to furnish a supply of this beverage.

Many sweet-scented herbs and shrubs, including 
mints, sages, and sweet grass, are still found here, and furnish the favorite perfumes of many tribes of Indians.

Water, noted for its scarcity, is not so scarce as it seems when all the hidden springs and pot holes are known. Almost every cave contains plenty of water for drinking and cooking purposes, even if this has to be caught in jars set under slowly dripping stalactites, and most contain pools of clean, cold water. Many deep pot holes in the rocky beds of canyons and side gulches hold water from one rain almost to another, and if covered with slabs of rock will hold it for an indefinite period. There are always good springs or streams within reach even in dry times, but a knowledge of the game of locating the water holes was of vital importance in occupancy of the desert.

Economy of the water supply may have rendered soap a luxury, but various roots, especially those of the "soapweed," Yucca radiosa, provided an ample supply of soap when needed, and of a quality still appreciated by many.

Materials for baskets were found in the pliant stems of skunk bush, the tough leaves of yuccas and bear grass, and the black fibers of the unicorn plant, while many variously colored stems and roots gave beauty of pattern. The pinyon tree furnished pitch for waterproofing the water baskets, which were lighter and more durable than pottery, and a bunch of fresh green grass or leaves served as a convenient cork to keep the water in and the insects out. Baskets for every household need are still made and used by the Mescalero Indians, and older types are found in the burial caves of the aborigines. 
Pottery clay of excellent quality and various colors is found in many of the caves, and in the great Carlsbad Cavern it lies in deep beds, moist and ready to be moulded into household utensils. Bits of broken pottery observed around the mouth of the cave and in the old mescal pits show good workmanship and varied patterns and designs of decoration.

To what extent paints and dyes were used can not be fully known, nor can the source of supply, but beds of bright red and yellow clays are found at no great distance. The black designs so common on the pottery may have been of mineral origin, or charcoal burned into the clay.

Native plant dyes are varied enough to stimulate the artistic senses so marked in some and deficient in other tribes of primitive peoples.

So far as known at present, this cave region was the stronghold of the warlike Apaches from the time of Coronado in 1540 until about 1870 when they were driven out by the white settlers. How far back their occupancy reaches, or who lived there before them, is not well known, but it is little wonder that they fought long and savagely for their land of comfort and plenty. 


\section{CHAPTER 5 \\ Mammals of the Region}

In the area surrounding the Carlsbad Cavern and extending about forty miles from the Pecos River at four thousand feet altitude on the east, to the top of the Guadalupe Mountains above nine thousand feet on the west, three of the transcontinental life zones are represented, each characterized by a considerable variety of animal life. Above the valley floor to the west, long limestone ridges and benches rise higher and higher to the ragged crest of the range, and are deeply cut through by numerous steep gulches and picturesque canyons. Great numbers of small caves open in the canyon walls, and many extensive caverns have been discovered all occupied to some extent by the animal life of the region. Some of the animals are dependent upon the caves and many others are influenced by them.

No attempt has been made to obtain a complete list of the mammals of this area, but about fifty species are known to occur, and further study will add others. The buffalo and Merriam elk, formerly abundant, and the less common grizzly bear, are gone, but some of the other large game animals are still found in numbers.

\section{BUFFALO}

Bison bison bison (Fig. 15)

In 1540, Coronado had his first view of the Pecos River and of the buffalo at about the same time and 
place, near where the Santa Fe railroad now crosses the river at Ribera; and in 1584, Antonio de Espejo traveled down the Pecos River Valley from this point one hundred and twenty leagues, "all the way through great heard of buffaloes." Other early writers spoke of the abundance of buffaloes in this valley, which apparently marked their westernmost limit in New Mexico within the period of its written history. It was the hunting and fighting ground of native tribes of Indians from farther west, who came to get a supply of buffalo meat, but made little impression upon the great herds that grazed over the grassy valley and watered at the great river or at the many smaller streams and pools to the west. With the coming of white men, the buffaloes were rapidly destroyed or driven back, and the last of which we have record were killed in the valley in 1884 and 1885 . Up to 1900 their old trails leading down from the plains and the deep cuts worn into the Pecos River banks were still conspicuous landmarks, but now these old trails have been so long used by domestic stock as to have lost much of their original character, and with them the last traces of the buffalo have all but disappeared from the valley.

A herd of domesticated buffaloes (numbering in 1923 about fifty-four) is kept on the McKenzie Ranch near Fort Sumner, and in 1925 thirty-three buffaloes were reported on the Bell Ranch, while several other privately owned herds are kept in western Texas. A stray buffalo bull wandering up and down the Pecos Valley near Carlsbad during the spring of 1924, was driven into a corral, teased into a fighting fury and 


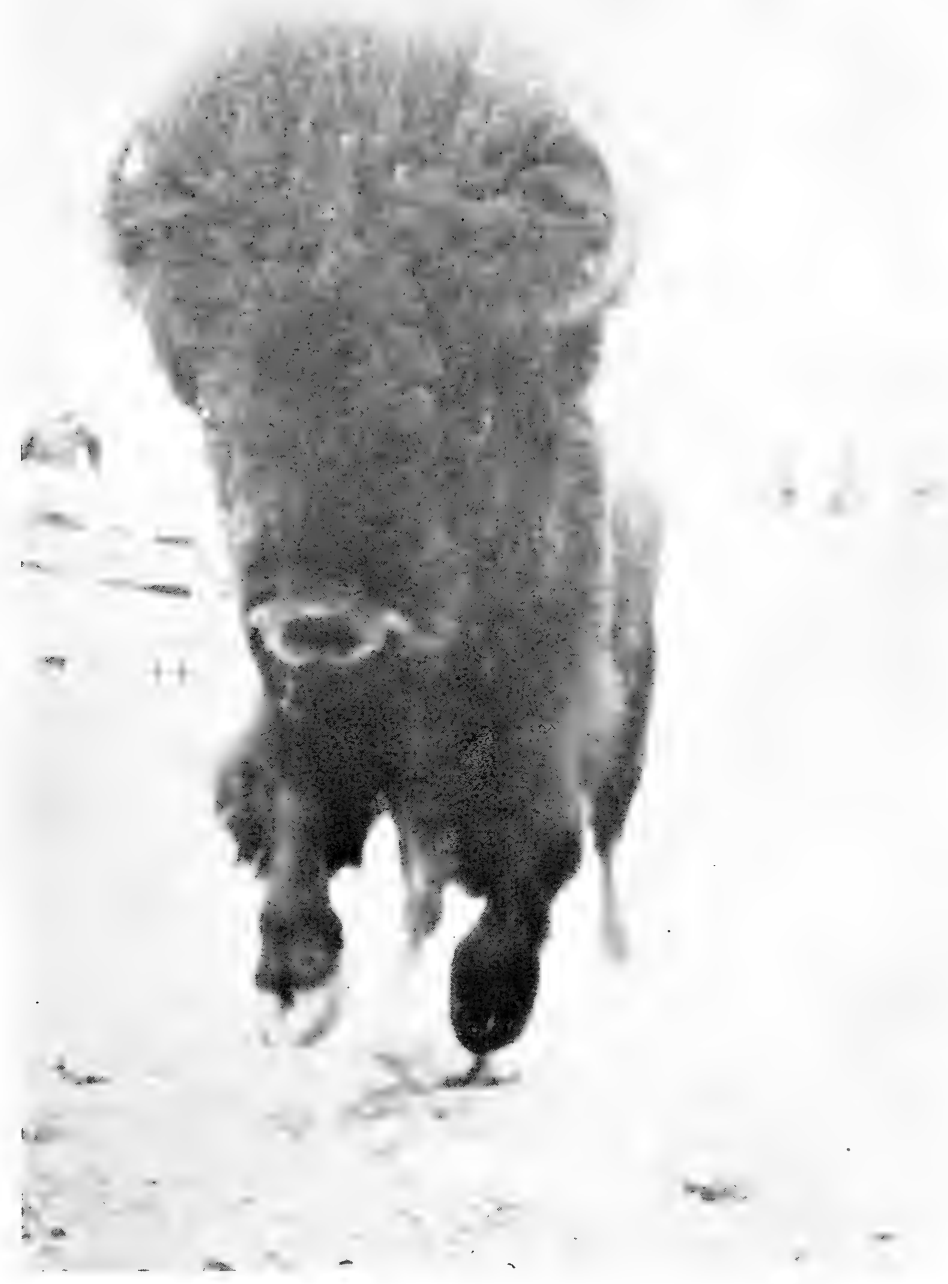

Fig. 15. An Old Bull Buffalo Charging the Camera

This bull had evidently escaped from a tame herd in the Pecos River Valley, but when driven into a corral near Carlsbad and photographed in April, 1924, his tameness had entirely disappeared. 

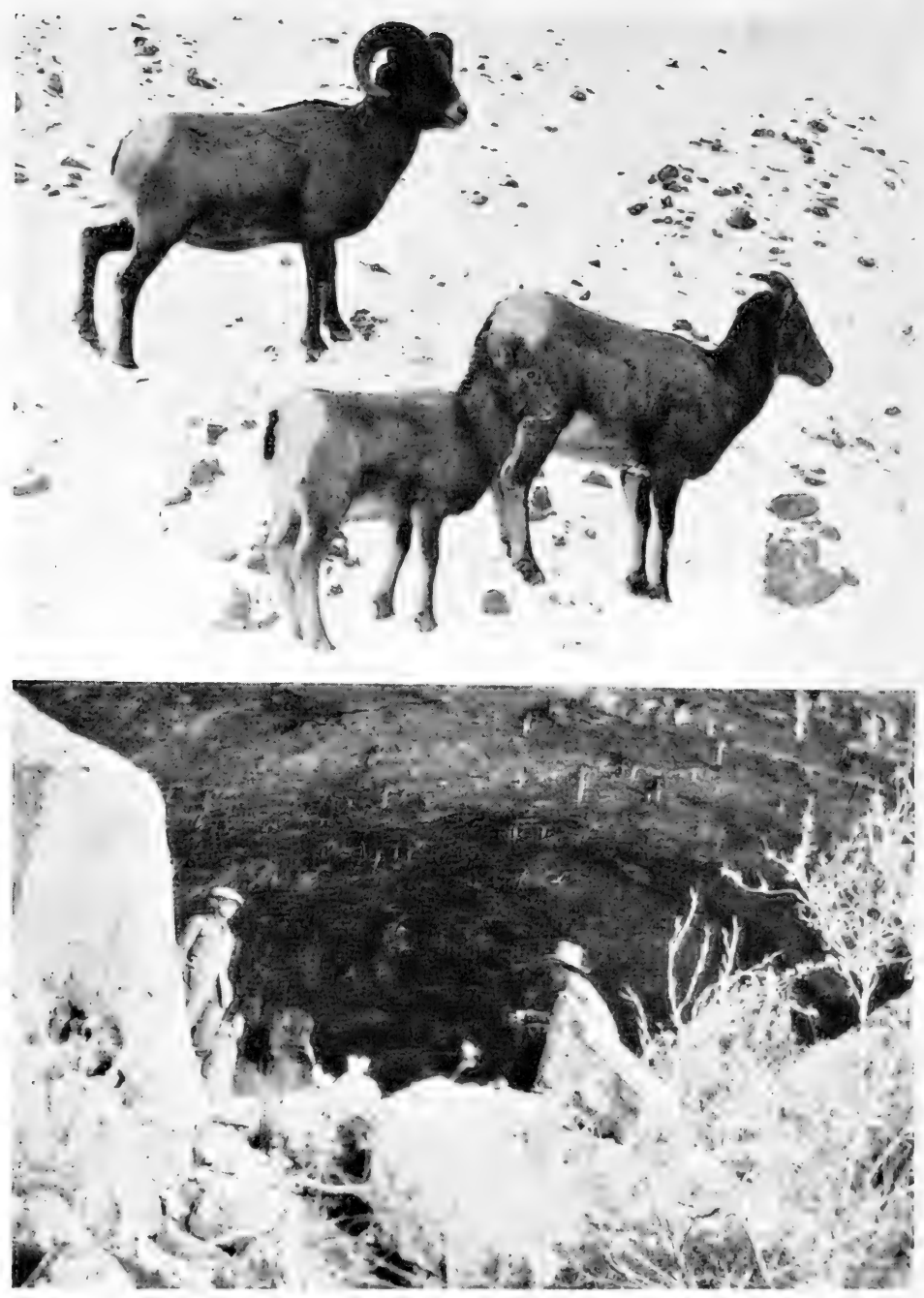

Upper: Fig. 16. A Trio of Mountain Sheep in Yellowstone Park Lower: Fig. 17. Entrance to a Large Cave in Slaughter Canyon not Far from Carlsbad, New Mexico

This cave has been used for ages by mountain sheep as a refuge from storms and from heat and cold. 
photographed by a crowd of excited spectators, then turned out to roam again over the valley. From just below the great Carlsbad Cavern the wide plains stretch eastward to the low horizon of the Llano Estacado, and before the white man came, the view over the valley must of ten have included vast herds of buffaloes.

The buffalo is our largest North American representative of the Bovidae or Ox family, large bulls sometimes weighing upwards of two thousand pounds and cows one thousand two hundred pounds.

\section{TEXAS MOUNTAIN SHEEP; BIGHORN}

Ovis canadensis texiana (Figs. 16 and 17)

The herds of Texas bighorns, which have long struggled for existence in the Guadalupe Mountains on both sides of the state line, are just about holding their own against predatory animals and predatory man. The most optimistic estimate of their numbers in the whole of the Guadalupe Range does not run above a hundred individuals, although there is ample room and ideal range for several thousand. They are scattered along the heads of Slaughter, Big, Franks, Gunsight, McKittrick, and Guadalupe canyons, mainly on the eastern slope of the range. Formerly they came down to Rattlesnake Canyon, and undoubtedly to Walnut and Dark canyons even below the present level of the Carlsbad Cave.

I found these sheep on April 29 and 30, in Slaughter Canyon, where fresh tracks and trails were conspicuous in one of the big caves high up on the canyon side. 
For ages evidently this cave has been used by considerable numbers of bighorns as a refuge from storms, and the spring, or drip pool, of excellent water in the far end of the cave seems to be visited at all seasons. A good sheep trail led into the cave from the rough ledges half-way up the terraced canyon wall, while fresh tracks and beds showed in the old, deep covering of sheep manure on the floor. A few very old skulls of mountain sheep were picked up near the doorway of the cave. The cave room, one to two hundred feet wide, by four hundred feet long and seventy-five feet high, half-lighted by a great arched opening on the west side and a small doorway on the east, affords an ideal shelter for comfort and protection. It is one of the caves showing no signs of human habitation, but was probably used as a game trap by human occupants of neighboring caves, as well as by predatory animals. Bear tracks are sometimes found in the cave, but the sheep would have a fair chance of escape from either bears or mountain lions, as the cave is large and open, and the sheep lie on the high slope of broken rocks, which gives them the advantage of a mountain slope for protection and escape.

Another larger cave in the head of Big Canyon is said to be much frequented by mountain sheep. There are also hundreds of smaller caves with wide open fronts all along the canyon walls, affording protection from storms and helping to make this an especially favorable range. The mountain slopes are densely covered with chaparral, mountain plants and grasses. The sheep are especially fond of the browse of mountain 
mahogany, syringa, Ceanothus, and other common shrubs, and feed to a great extent on the smaller plants, and probably to some slight extent on grasses. They have no competitors in the range except mule deer, as horses, cattle, and domestic sheep and goats do not penetrate to these steep, rough, upper slopes, and the forage is untouched except by game animals, which at present make little impression upon it.

The whole summit and eastern slope of the Guadalupe Mountains from Guadalupe Peak in Texas north to Dog Canyon in New Mexico should be a game refuge. It could easily support at least one thousand bighorns and five thousand mule deer, as the deer range lower and more widely than the sheep. If the game were protected, and their natural enemies were destroyed, the range would soon be fully stocked. Under intelligent control and a definite plan for use of the game, either for hunting or stocking other ranges, it should be not only self-supporting but a valuable property.

The Texas bighorn differs from the Rocky Mountain species in slightly paler colors and heavier dentition, and occupies a lower zone.

\section{PRONGHORN; ANTELOPE}

\section{Antilocapra americana americana}

Antelopes are still fairly common in places within sight of the cave. On April 30, 1924, O. G. Babcock saw two not far from the road near Loving, a small town just south of Carlsbad, and several small herds 
were reported south of the cave, just over the Texas line. Marvin Livingston told me there were about forty antelopes on his ranch, some thirty-five miles east of Carlsbad, and he estimated five hundred in eastern Eddy and western Lee counties. It is largely through the efforts of intelligent and public-spirited ranch owners that any individuals remain, for the problem of legal protection has been exceedingly difficult on these wide, open areas where the antelope once roamed in untold numbers. Legal and official aid alone can never save them, but local interest and vigorous action on the part of the residents can do much to postpone and possibly prevent the national disgrace of allowing this unique species, one of our most interesting game animals, to be exterminated.

The pronghorn is not a true antelope, but belongs to a family of its own, peculiar to North America and characterized by deciduous horns with a single flattened prong at one side.

\section{MERRIAM ELK; ARIZONA WAPITI}

\section{Cervus canadensis merriami}

The Merriam elk are gone from the Guadalupe and Sacramento mountains, where they were once abundant and from which area they may well have moved in winter down to the Mescalero Cave level. At any rate they were within an easy day's hunting trip from the cave and undoubtedly afforded one of the important sources of game and food supply for the local aborigines. A set of horns of this elk, picked up near the head of 
Ruidosa Creek about thirty years ago, was seen at the home of Marvin Livingston in Carlsbad. They are of a three- or four-year-old bull, rather light, but with the full equipment of six points each. They show no marked subspecific characters, but heavier horns with part of the skull attached, found on the upper Penasco in 1902, served to identify this southern form of elk, which is now extinct and represented by only a few museum specimens.

The Merriam elk is a large form with very heavy antlers, and in coloration and general appearance differs little from the Rocky Mountain elk.

\section{PLAINS WHITE-TAIL DEER}

\section{Odocoileus virginianus macrourus}

A few white-tail deer still cling to the "shinnery" of the sand dune region east of Carlsbad, where they are to some extent protected by the large ranch owners. Without such interested protection they would long ago have disappeared from this open and easily accessible country, and the spirit in which it has been given to such rare animals is highly commendable.

A few white-tail deer also live in the region between the Upper Penasco and Ruidosa along the eastern edge of the Mescalero Indian Reservation. This is often spoken of as the white-tail country, as it is the only place in these mountains where these animals occur.

The plains white-tail deer is a pale western form of the Virginia white-tail, with small ears, long, bushy tail, and the prongs of the antlers rising from a single beam. 


\section{Odocoileus hemionus canus}

The gray mule deer are still common in the canyons and gulches west of the Carlsbad Cavern, and increasingly more abundant farther back toward the Guadalupe Mountains. On the upper slopes of Slaughter Canyon, above the range of Angora goats, they are so abundant as to make good trails over the chaparralcovered slopes. Much of the country is so rough that domestic stock does not compete with mule deer and bighorns for the abundant browse on these wild and picturesque upper slopes, which will always have a greater value for game than for other purposes. Abundance of mountain mahogany, syringa, Ceanothus, scrub oak, and manzanita afford favorite food at all seasons and would support a far greater deer population than is found there at present. The mule deer range is mainly on land that has been withdrawn from entry and which should be kept for game and recreational purposes. It is unsuited for agricultural use, but is wildly picturesque and full of interesting plant and animal life. It is only necessary to control predatory animals and hunting to increase the game animals to any desired numbers.

The gray mule deer is a pale desert variety of the Rocky Mountain form, with the same large ears, small, black-tipped tail, and doubly forked antlers. 


\section{PECCARY; HAVELIN}

\section{Pecari angulatus angulatus}

The Texas collared peccary, or havelin, still inhabits the "shinnery" of the Mescalero sands along the east side of Pecos River, thirty-five miles east of Carlsbad. Two were killed here about ten or twelve years ago, but the small remnant is protected by the ranchmen on whose land the animals range. Several skins and mounted heads were seen at the home of Marvin Livingston, who greatly prizes not only the peccaries but the antelopes and white-tail deer on the Livingston ranch.

These little tailless pigs with dark gray coats, marked by light-colored collars, are peculiar to America.

\section{VIRGINIA OPOSSUM}

\section{Didelphis virginianus}

Opossums barely reach the southeastern corner of New Mexico, but recently a few have escaped from captivity at Carlsbad, where they might easily become established as successful residents under the advantage of cultivated land, good cover, and abundant and varied food supply. The whole Pecos Valley will undoubtedly become the home of these peculiar animals, which thrive even in populous areas because of their great fecundity and tenacity of life, in spite of numerous enemies and edible qualities. Generally their value for fur and food more than compensates for occasional mischief in hen houses, and places them in the class of game rather than of vermin. 
The opossums are our only representatives in the United States of the great order of marsupials, or pouched mammals, and are easily recognized by the abdominal pouch in which the young are carried, by the long, nearly naked, and prehensile tail, and the naked ears, sharp nose, and pretty gray fur.

\section{TEXAS ARMADILLO}

\section{Dasypus novemcinctus texanius}

The Texas armadillo strays into southeastern New Mexico at times, but can scarcely be claimed as a regular inhabitant. One was found near Carlsbad in February, 1924, but whether it was killed or was allowed to go free, I did not learn. They are wholly useful and entirely harmless animals and should be protected and encouraged rather than destroyed. The use of their shells as baskets should be condemned and discouraged in every locality.

The armadillo is known by the hard shell covering its body, which is rendered flexible by nine movable bands across the back.

\section{TEXAS JACK RABBIT}

\section{Lepus californicus texianus (Fig. 18)}

The large, gray Texas jack rabbits are abundant over the valley country, but they rarely get up on the rocky ridges around the cave, nor nearer than the edge of the flats a couple of miles to the south. Still their bones form a part of the refuse under the owls' nests in the 
mouth of the cave, and rabbits undoubtedly formed no small part of the meat supply of the aborigines who formerly inhabited the cave and the adjacent region. Over the valley country they are the most conspicuous animals, half a dozen being often seen from one point as they feed on the tender growth of early spring vegetation, sit in the shade of desert bushes, or go loping away from the roadside. Two or three dozen were usually seen on a trip from the cave to Carlsbad, a distance of twenty-six miles, but most of these were in two or three low basins where vegetation was getting an early start. Out over the dry flats and ridges only an occasional rabbit was seen, and their total numbers would probably not average more than three to a square mile of the valley country. In this scattering and about normal abundance they are of little economic importance and may prove an asset rather than a liability, for they help to feed the coyotes, eagles, hawks, and owls and thus prevent more serious depredations on live stock and game. The grass and weeds eaten by the rabbits are mainly good stock food, and a considerable increase in the number of rabbits would seriously impair the grazing capacity of these arid valleys.

One full-grown, old male jack rabbit, shot for examination, weighed $6 \frac{1}{2}$ pounds, and measured in total length 600 millimeters; tail vertebrae, $70 \mathrm{~mm}$.; hind foot, $133 \mathrm{~mm}$; and ears from crown to tip, $160 \mathrm{~mm}$. This was an average and not an extremely large animal. The contents of its stomach, half full of green food, weighed 59 grams, and when air-dried 15 grams, show- 
ing a loss of about 75 per cent by weight of water. Its bladder was distended with fluid from the excess moisture of its food above the little carried away by the relatively dry pellets. This faculty of extracting moisture from their food readily explains the ability of these animals to exist in arid regions at long distances from water, and actually to live their whole lives without ever drinking water. They are one of the many species of rodents thus perfectly adapted to desert life.

This large jack rabbit is recognized by its very long legs and ears, its general light gray color, and black upper surface of the tail.

\section{SMALL COTTONTAIL}

\section{Sylvilagus auduboni minor (Fig. 19)}

These little cottontail rabbits live all over the Pecos Valley and on the limestone ridges about the Carlsbad Cavern. They are most numerous close to the cave buildings, where coyotes are kept away by the presence of people and dogs, and where safe shelter is found in the rocks on the canyon sides. No cats were kept at the cave camp, and the one little yellow dog did not chase rabbits and would not have killed a mouse, but he barked at night and probably helped to keep away coyotes and other animals. These rabbits are also abundant in the prairie-dog towns of the valley below, living in the burrows and keeping as close to these underground strongholds as do the prairie-dogs, and seeking them as promptly when danger threatens. 

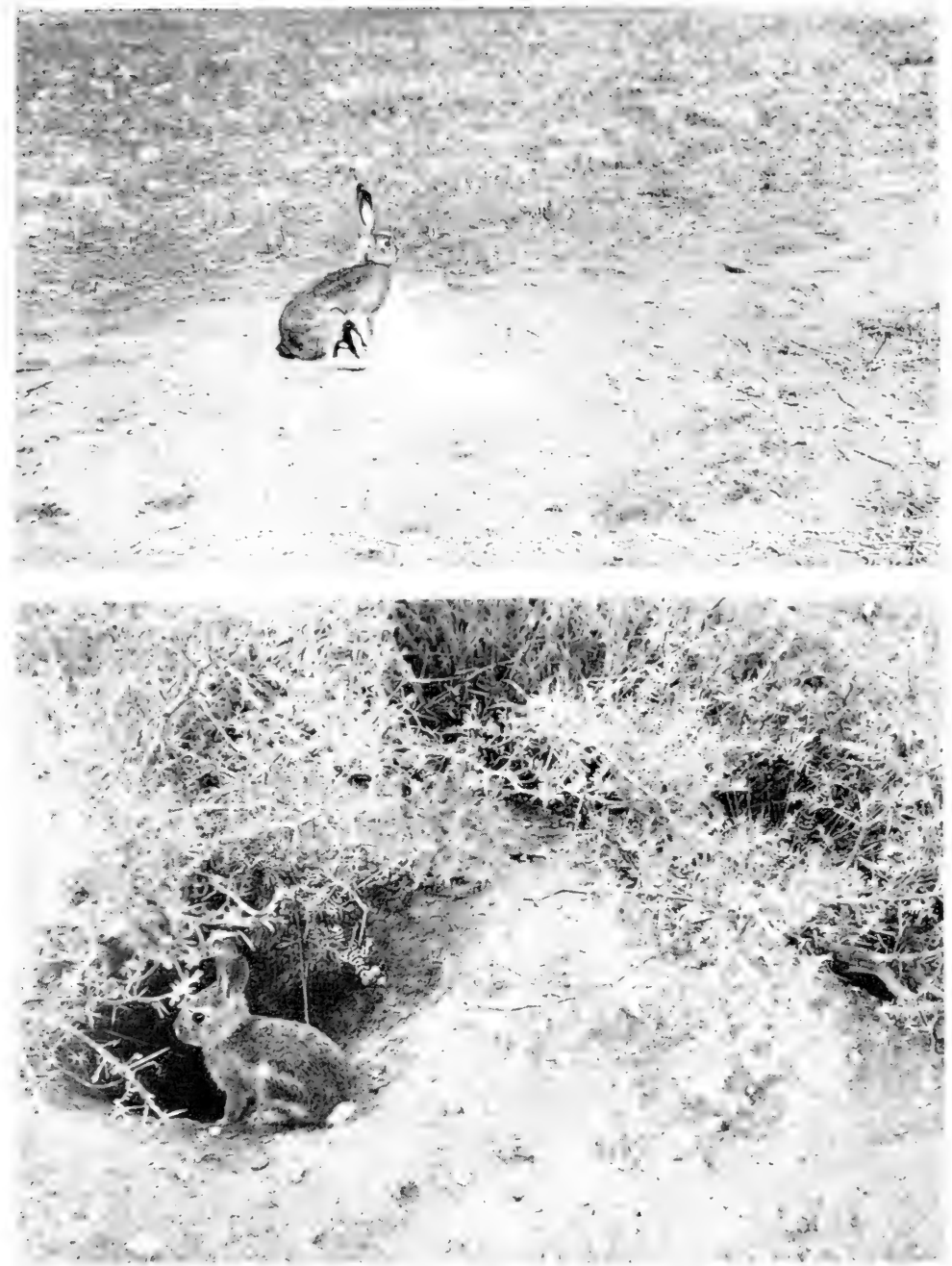

Upper: Fig. 18. Jack Rabbit in Open Valley, with Plenty of Room to Use its Eyes, Ears, and Legs

Lower: Fig. 19. Small Cottontail (Sylvilagus auduboni mixor)

In the open country these little cottontails depend on burrows of badgers and prairie-dogs for protection. 


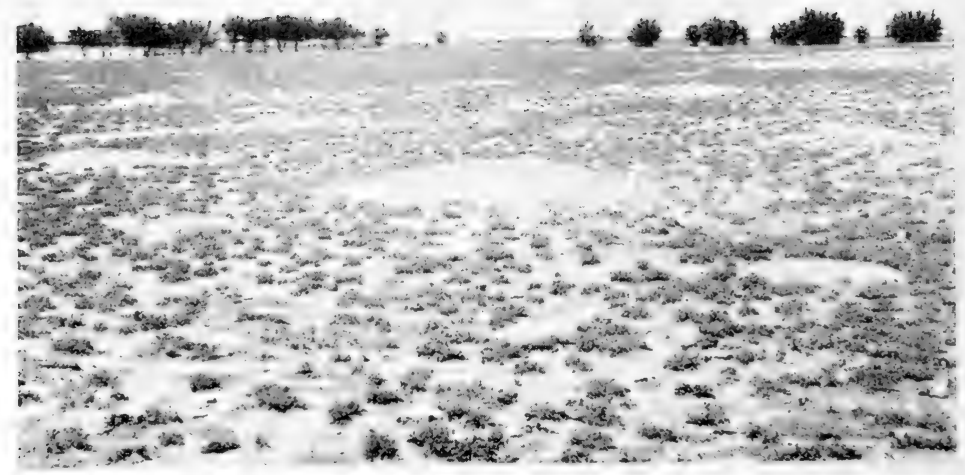

S. r.
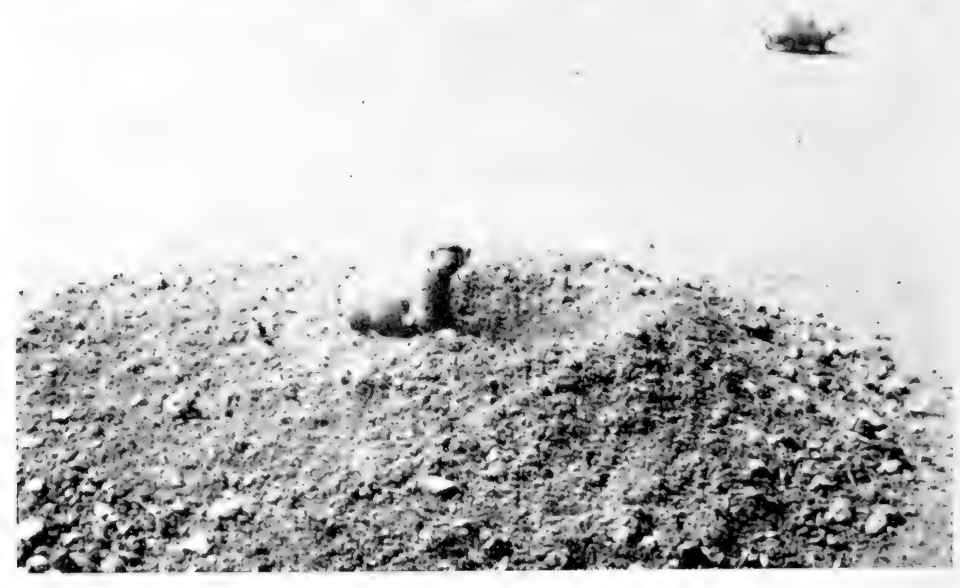

Upper: Fig. 20. A Prairie-dog Town m ax Alfalfa Field

Near Carlsbad, New Mexico, in 1901

Lower: Fig. 21. The Prairie-dogs Build Mouxds about Their BURrows

This prevents the water from running down them in case of heary rains. 
Keen eyes and ears and quick legs are the only defense or protection of these timid little folk, but in spite of rocks and burrows, the great numbers of their bones found in the owl pellets in the cave show how extensively they are preyed upon. Apparently more of their bones occur under the owl nests than do those of any other mammals, except possibly those of wood rats, which are about equally abundant. On March 25 , about half of a freshly killed cottontail was found in the nest with three young of the great horned owl, and the crops of the downy young about five days old were bulging with the tender rabbit meat, picked off and fed to them by the mother bird.

Generally, the cottontails are healthy and good eating. The half-grown young are especially delicious, and there are usually plenty of them for camp meat during the summer when other game is out of season. To the aborigines they doubtless were an important source of food supply.

Long accustomed to desert conditions, these rabbits are entirely independent of any supply of drinking water, and get an abundance of moisture from their green food. In winter there is always cactus to be found, while many plants store moisture in underground roots, bulbs, and tubers, always available to such rodents as know where to find them.

This little cottontail is one of the smallest of our rabbits of this group, with rather prominent ears and a short, puffy, turned up tail showing the white lower surface. 
ROCK SQUIRREL

\section{Citellus grammurus grammurus}

The rock squirrels can climb trees, and would do so if there were any near, but they are generally found, as their name implies, among the rocks. At the Carlsbad Cavern they are common along the canyon walls and around the entrance, but only in a very small way are they cave dwellers. They often live in little caves or in clefts of the rocks, or under heaps of broken rock talus where the cavities are small enough to exclude such enemies as foxes, bobcats, ring-tails, skunks, and other carnivores. They are sturdy animals, and fierce fighters when cornered, but really they are timid and shy, and their main protection lies in rocky cover and eternal vigilance. They are often seen sitting up on rocks or points of the cliff on the watch for enemies, and when danger approaches they give a sharp whistle as a warning to friends and families, and all rush to cover. A few living in the low cliffs near the cave shaft came regularly for the grain scattered for them and the quail. They were often seen sitting on the rock pile below the bunk house, but quickly disappeared if a person approached. With continued feeding and protection they would become very tame and would be a source of much interest and pleasure to visitors at the cave. In spring they are especially eager for grain or any extra food available, but later when the little black walnuts and acorns are matured, they find an abundance of rich food and become very fat. They are as good eating as any squirrels. One that I took for a specimen, 
after the skin and skull had been saved and the stomach examined for notes on food habits, furnished me a hearty lunch when I was out all day in Walnut Canyon.

The rock squirrels are large, heavy-bodied, bushytailed, gray animals of the ground-squirrel group, about the size of the eastern gray squirrel.

\section{MEXICAN GROUND-SQUIRREL \\ Citellus mexicanus parvidens}

These large, striped-backed ground-squirrels are common in the Carlsbad region and over the Pecos Valley, but none was seen up on the ridges near the cave. They are burrowing animals and mainly restricted to the mellow-soiled valley country, or where they can find easy digging for their burrows under mesquite, creosote, or other sheltering bushes. The first one seen was on March 11, the day of my arrival, which may well have been about their first appearance from hibernation. Others were occasionally seen on warm days during most of my stay, or up to May 3, and all had the long fur and large bushy tails of the winter coat. Rarely are they so numerous as to be of any serious economic importance, and the slight damage they sometimes do to crops may well be compensated by their destruction of weed seeds and insects.

The Mexican ground-squirrel is easily recognized by its striped back, short ears, and long, slender tail. It is much smaller than the rock squirrel and lives in the valley. 


\section{BLACK-TAILED PRAIRIE-DOG}

\section{Cynomys ludovicianus (Figs. 20 and 21)}

Colonies of these plump little yellowish burrowing squirrels are scattered over the Pecos Valley and on many of the more fertile mesas and mountain slopes. They are generally located on the richest and mellowest soil, where digging is easy, and where the short grass and low vegetation furnish abundant food. Sometimes a colony will cover hundreds of acres, comprising thousands of burrows and great numbers of prairiedogs; again there will be only a dozen burrows and about as many occupants, and on rare occasions one or two are found alone. Naturally they are not on the limestone ridges about the cave, but they are common along the Black River Valley only two miles to the south, where they lay a heavy tax upon some of the best forage. In places they have dug up and entirely destroyed the vegetation on considerable areas and have been forced to move on to find a better food supply. They prove a serious handicap to stock raising as well as to any form of agriculture, and are generally destroyed in every way possible, mainly by means of poisoned grain scattered about their burrows.

These prairie-dogs are really large plump squirrels with little, short, flipping, black-tipped tails, short ears, short yellowish fur, and voices somewhat like the yip, yip, yip, of a small dog. 


\section{CAVE MOUSE}

\section{Peromyscus leucopus tornillo (Fig. 22)}

The only mammals living their entire lives, being born and reaching old age, in the dark depths of the great cavern, are the cave mice, or the west Texas form of the white-footed mice, near relatives of our eastern whitefooted or deer mice. They are rather large, heavy bodied mice with not very long tails, and specimens from the cave seem to differ from those outside only in larger size and better development, differences easily accounted for by protection from natural enemies, long life, and abundance of food. Evidently they have not been restricted to the cave long enough to have undergone important physical changes. They may originally have fallen in, and not being expert climbers were unable to climb out, and so adapted themselves to cave life and wandered to the farthest rooms. If so, their imprisonment would probably extend back only about twenty-four years, or to the time when the guano came up much nearer to the entrance and must have made the exit comparatively easy.

These mice are fairly common in the King's Palace and especially in the lunch room beyond, all through the great south room, and in the deep room below it, reached by a hundred-foot wire ladder, as well as in the guano rooms and large halls near the entrance to the cavern. Their little round tracks and well-worn trails usually follow the edge of the walls, or cut across from one point of rocks to another, taking the shortest lines of travel from one protecting cover to another. 
How they find their way about or locate their food in the utter darkness is still a cave mystery. Their eyes appear normal, and they can see well when brought out to the light, although many of those born and raised in the far rooms could never have seen a ray of light before. They are no different in color from those living outside, a dull buffy gray above and white below. Occasionally one running over the floor of the cavern was seen by lantern light, but most of those taken were caught in traps set along the runways and baited with rolled oats. More were caught in the daytime than at night, but probably there is no difference in the periods of their activity unless in the first large rooms where a faint trace of light from the openings would make it possible for them to see during the daylight hours. That they are permanent residents of the cave is shown by the fact that most of the females caught were nursing young or contained three to six embryos. Most of those caught in March and April were adults, for the young were not yet large enough to run about or get into traps. Those taken were larger and fatter than the same species caught outside, evidently as a direct result of comfortable climate and abundant food.

The stomachs of those taken for specimens were filled with remains of cave crickets, in addition to remains of tourists' lunches and rolled oats used for trap bait. The crickets, which are abundant throughout the cave, seem to be their main and only permanent source of food supply.

The cave mouse with medium long tail differs from the eastern white-footed mouse mainly in slightly paler gray brown color. 

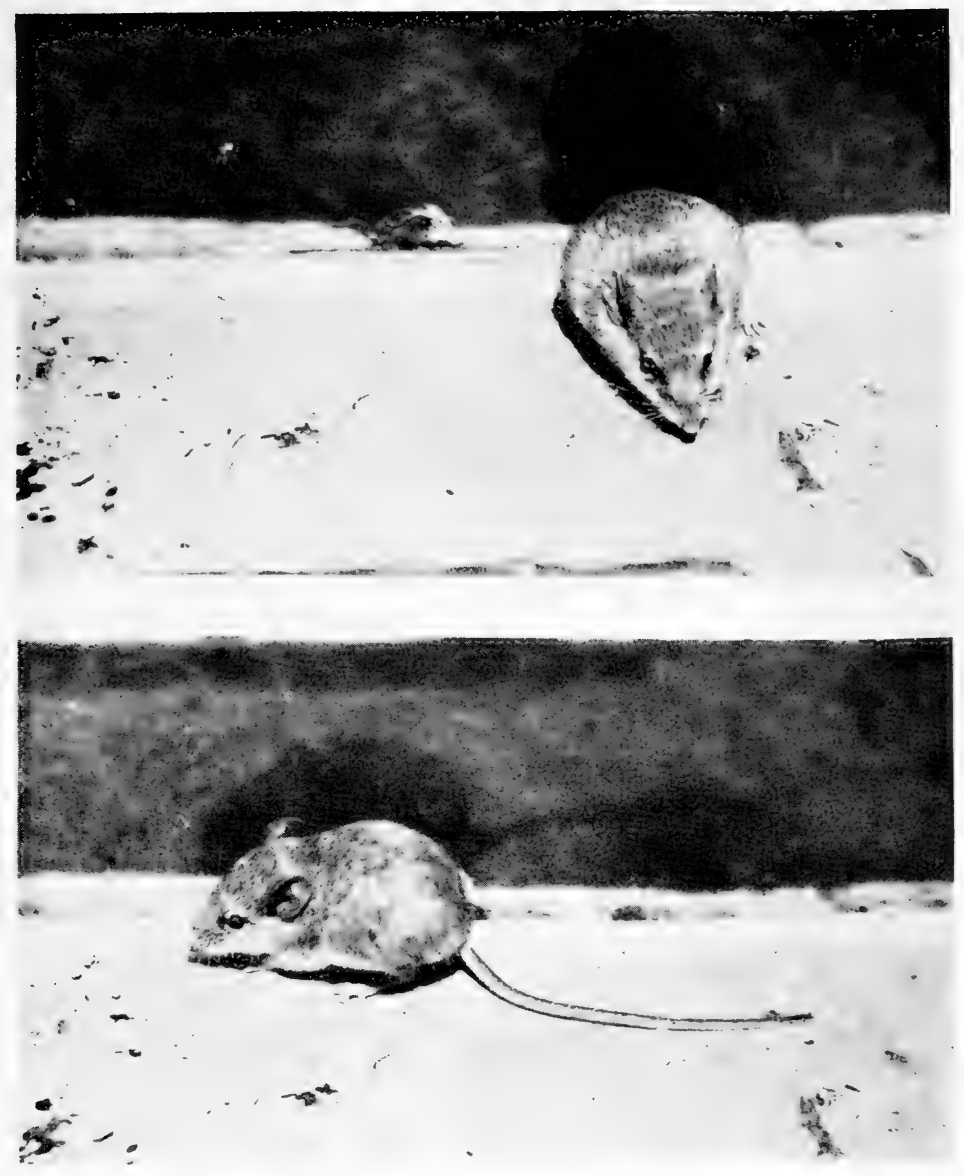

Upper: Fig. 22. The Cave Mouse (Peromyscus leucopus TEXENSIS)

The only mammal found living permanently throughout the great Carlsbad Cavern.

Lower: Fig. 23. The Cliff Mouse (Peromyscus boylit rowleyi) Common in the first rooms of the great cavern 

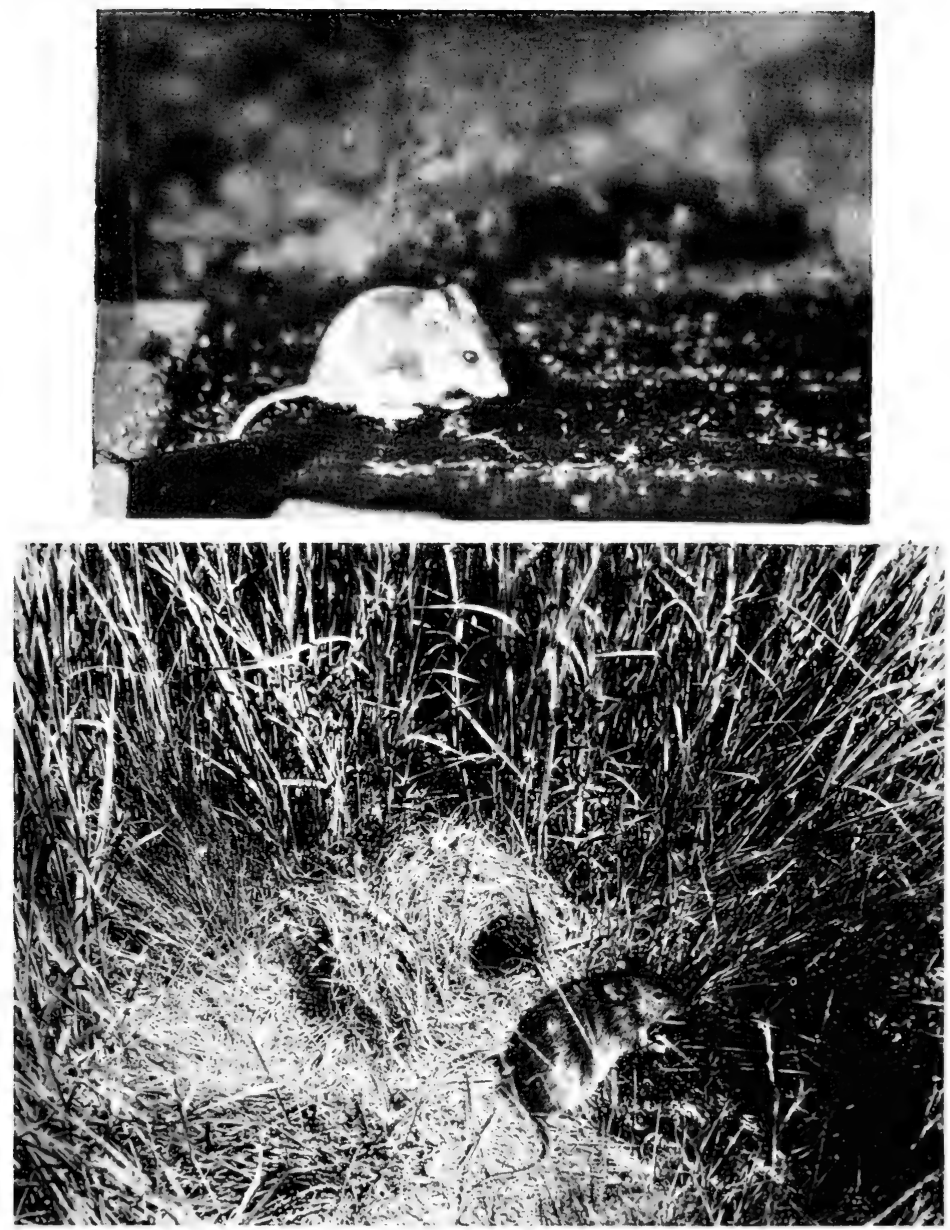

Upper: Fig. 24. Grasshopper Mouse (Onychomys torridus TORRIDUS)

An insect-eating rodent of the arid region

Lower: Fig. 25. Texas Cotron Rat (Sigmodon hispidus TEXIANUS)

A small rodent of the grassy valley bottoms 


\section{CLIFF MOUSE}

\section{Peromyscus boylii rowleyi (Fig. 2.3)}

The only other species of mouse in the cavern is the cliff mouse, a slender, graceful, large eared little animal, with a long, hairy tail, and a famous rock dweller and cliff climber of the deer mouse group. Specimens were taken in the first rooms of the cave only, and none beyond the traces of daylight that came in through the natural openings. Some of those caught in the cave had green food in their stomachs, telling of visits to the upper world of light and green vegetation, while others on the cave floor, two hundred feet below the surface, were feeding entirely on cave crickets and the rolled oats with which my traps were baited. In winter they may make still more use of the cave, for they were abundant in the cliffs and buildings outside, apparently being the most abundant mammal of the region. In Jim White's cabin they were rather troublesome until my traps set in the corners and around the wall removed seventeen of them, after which only an occasional mouse was caught. Some were caught in the bunk house, and in an upper bunk one had a beautiful nest, a hollow ball of tow with a hole in one side. In my little cabin they were not disturbed and did not disturb me. Several were kept in cages with two kinds of wheels for play and exercise, and these wheels were kept busy all night and part of the day. When ready to leave, I left the cages open and the cliff mice went where they pleased, scampering over my bed, across my face, and examining my hair with dainty hands. For a part of 
the night they returned to the cages and ran their wheels, but in the morning had taken up new nest quarters under the floor. They are such clean, brighteyed, pretty little animals that they make interesting pets and would be very companionable, if not so shy and nervous. In proper cages, with revolving wheels, they are contented and happy and seem not to mind temporary captivity.

This mouse is about the size of the cave mouse but has a longer and more hairy tail, larger ears, and brighter color.

\section{GRASSHOPPER MICE}

Onychomys leucogaster ruidosae and Onychomys torridus (Fig. 24)

No grasshopper mice were collected near the cave, but specimens of the larger midosae have been taken on Penasco Creek, a little farther north, and the smaller torridus is common in Pecos Valley near Carlsbad, while the easily recognized jaws of both species were found in considerable numbers under the owl nests in the mouth of the great cavern. These big owls are extremely industrious and efficient collectors of small mammals, and wbile their specimens are not labeled for exact localities, they were doubtless gathered within a radius of a few miles of the cave, and furnish a good index to the species of the vicinity.

These sturdy, short-tailed little mice, while true rodents, are largely insectivorous and carnivorous in tastes and habits, sleeping by day in burrows in the 
ground and roaming at night in search of food,- grasshoppers, crickets, beetles, moths, scorpions, spiders, and any other mice or small animals that they can catch, kill, and eat. They possess many of the habits of real hunters, including a call note, a shrill little whistle like the miniature howl of a wolf, by which they keep in touch with each other at night. In the arid regions they take to some extent the place of the moles and shrews of the humid regions in the destruction of ground-dwelling insects and small animal life. In this respect they may well be as useful as birds in helping to maintain a wholesome balance of nature and in controlling the abundance of injurious forms of life. The owl perhaps deserves no credit for swallowing these useful little animals, and yet we can not be sure that in unchecked abundance even they might develop habits injurious rather than beneficial to our interests.

Grasshopper mice are thickset little fellows with short, fat tails, medium large ears, and the keen expression of hunting animals. They are dark gray or pinkish buff above and pure white below.

\section{WHITE-THROATED WOOD RAT}

\section{Neotoma albigula (Fig. 26)}

These rock-loving wood rats are abundant in the caves and canyon walls and every rocky place where safe cover can be found. None was found in the depth of the Carlsbad Cavern where it would be necessary for them to climb out every night to get a supply of green food, but they were living in the great western entrance 
back to the brink of the shaft that dropped one hundred feet into utter darkness. Every little nook and corner of the walls about the main entrance sbowed their tracks and trails, and many of the niches were filled with their trash piles or "houses" of sticks and bits of stones, bones, cow-chips, and food refuse. Some of the cabins and storehouses at the cave were occupied by them, and a soft nest of chewed up and finely shredded gunny sack was found in a section of stovepipe in a corner of my cabin. One of the wood rats was caught in a storehouse at the entrance to the ladder shaft leading down into the cave, where they came for grain and supplies and made nests in the stacks of guano sacks. They had at times been quite numerous in this building, as shown by accumulated pellets, but a little spotted skunk also had access to the storeroom and kept them away most of the time.

Their bones were the commonest of any rodent in the owl pellets in the caves and under the owls' nests along the cliffs, and were also found in droppings of ringtails, coyotes, and bobcats. They have many enemies, which probably accounts for their occupation of the rocky fortresses of cliff and canyon wall, and for the care with which they close their rocky doorways with sticks and stones and thorny vegetation. They are so highly edible as to be especially sought by birds of prey and carnivorous beasts, and presumably were eaten by primitive man. In their rocky strongholds, however, they are less easily obtained by man and by many other of their enemies than are the gray wood rats that depend on stick houses in the open valley. 

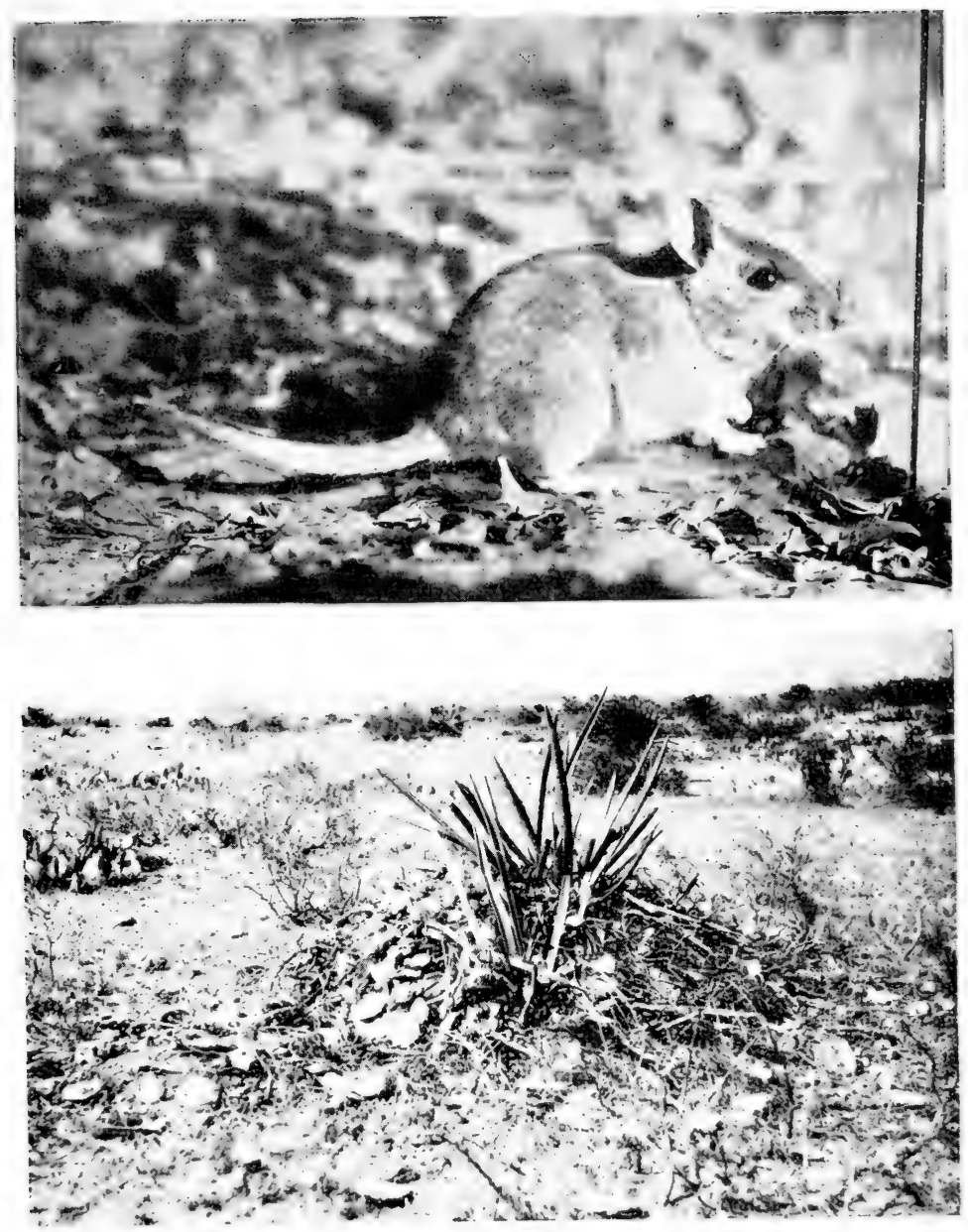

Upper: Fig. 26. The White-throated Wood Rat (Neotoma ALBIGULA)

Gentle animals, not closely related to our brown rats

Lower: Fig. 27. House of the Gray Wood Rat (Neotoma MICROPUS CANESCENS)

Built largely of cactus and around the base of a Spanish bayonet plant in the open desert. 

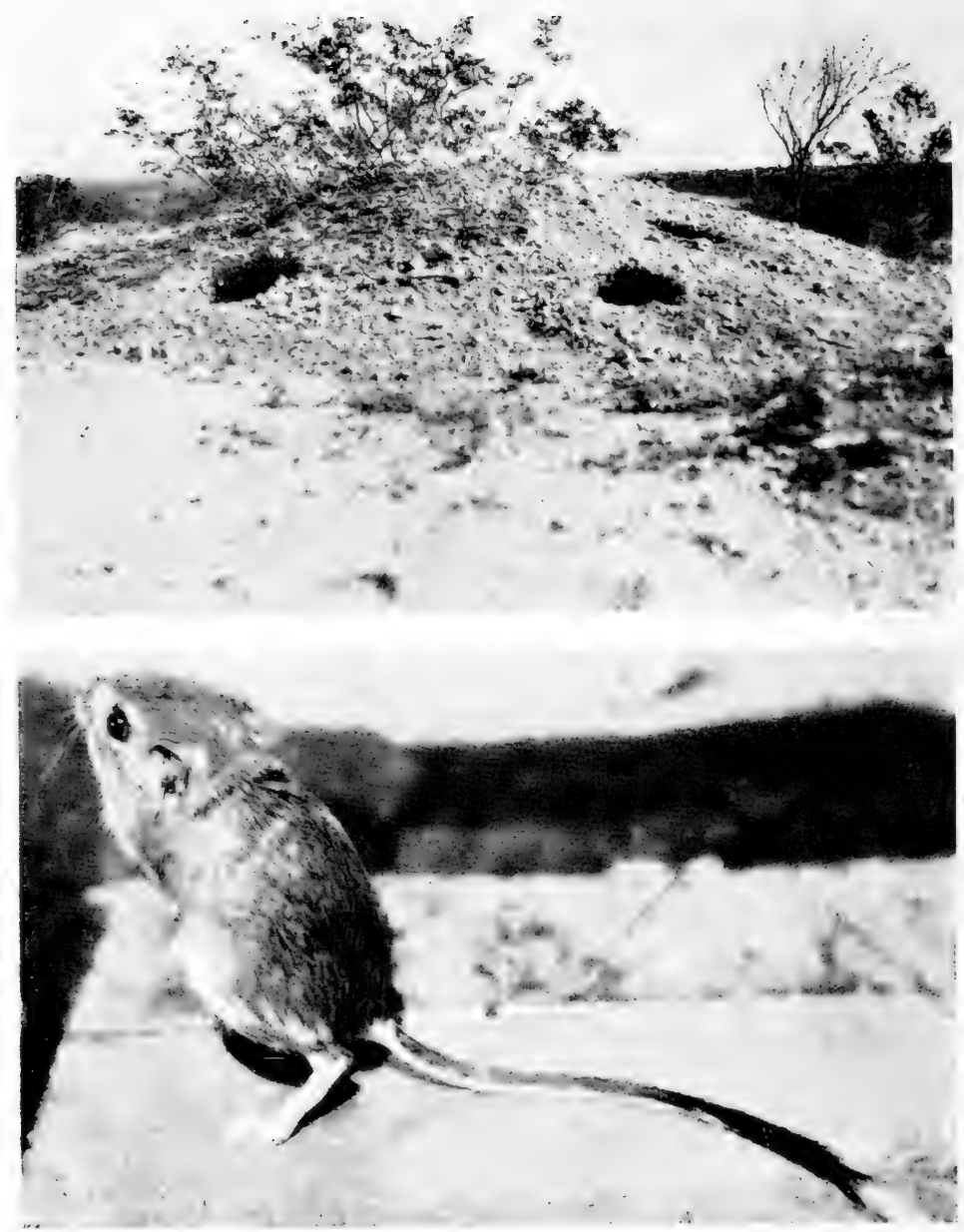

Figs. 28 and 29. The Banner-tail (Dipodomys spectabilis BAILEYI)

These largest of all the kangaroo rats build great mounds in which to live and store their food, and some of these mounds may be seen within a half mile of the cavern entrance. The animals are very gentle and make interesting pets. 
The white-throated wood rat is one of the smaller species, with round tail, large ears, and soft pretty fur of a buffy gray color over the upper parts, and all white below.

\section{GRAY WOOD RAT}

Neotoma micropus canescens (Fig. 27)

These ashen gray wood rats are numerous all over the valley country and even up over the open tops of the ridges, living away from the rocks in houses of their own construction under cactuses, yuccas, agaves, and other thorny or spiked vegetation. Often a heap of many bushels of cactus joints, thorny twigs, and branches, mixed with sticks, stones, dried cow-chips, bones, and other trash is seen in the midst of a cactus or lechuguilla patch, around the base of a daggerleaved yucca, or in a bush of allthorn or spiny mesquite. Numerous doorways enter the house from the sides and edges, and inside is a roomy dwelling place for the wood rats, where they may be safe and comfortable in their thorny strongholds, safe from many, but not all, of their enemies. The weasels and little striped skunks, the big bull snakes and rattlesnakes, can enter therein, and men can tear the houses to pieces with long sticks and catch the occupants. Still the wood rats are safe enough to become very numerous where there is plenty of cactus and other thorny material, and on some of the cactus-covered flats their houses will average two or three to an acre, and locally even more. Comfortable nests in the rooms of the houses or in hollowed-out 
spaces underneath, and an abundance of green food from cactus pads and a great variety of green plants, with many seeds, nutlets, and fruits, afford them comfortable and prosperous homes.

Trails leading from one house to another suggest a sociable life, but the storing habit, strongly developed in the species, puts a limit on their sociability. Rarely more than one adult is found in a house, but the young remain with their mother until well grown.

The mother wood rat, if alarmed or forced to leave the house, takes her small young with her, carrying the two to four little ones clinging for dear life with hooked incisors to her nipples while she drags them rapidly along the well worn trail to another house or to safe cover. Many times this saves the lives of the young, but not always, for foxes and other small carnivores can follow the trails and sometimes capture both young and old.

At the edge of one wood rat house I saw a shrike pecking vigorously at something, and on scaring it away found a half-grown wood rat, with broken skull, which the bird had been in the act of killing. Owls and the smaller carnivores get many, while hawks occasionally capture them early in the evening.

The gray wood rat is about the size of the whitethroated, but with shorter tail and clear ashy gray color above, and white below. 
Sigmodon hispidus berlandieri (Fig. 24)

This rough, gray cotton rat, common along the Pecos Valley in the alfalfa and grain fields, meadows, and ditch banks, and even up in the Guadalupe Mountains where bits of meadowland occur, was not found in the vicinity of the Carlsbad Cavern, but its jaws were picked up in the entrance under nest sites of the great horned owls. The cotton rats may have been brought from the farms along Black River, four miles distant, but may have been caught nearer by. The owls are most industrious collectors of small mammals, and cover the ground more thoroughly than we do.

Cotton rats, when numerous in cultivated ground, often prove very destructive to crops, not only cotton, but all grains, alfalfa, hay, and many other farm products. But for owls and such enemies they would be a serious menace to agriculture.

The cotton rat is between rat and mouse size, with coarse gray hair, medium long, tapering tail, and not very large ears.

\section{PECOS RIVER MUSKRAT}

\section{Fiber zibethicus ripensis}

These little pale muskrats are found in many places along the Pecos River and come nearest to the big cavern in the permanent pools of Black River, about four miles south. Here on the irrigated farmlands of "Uncle Bill Washington" a few are found, but they 
are not very numerous, and are trapped off to prevent any serious damage to the ditch banks and crops. In a country of irrigation ditches they often do serious damage by burrowing through the banks and letting the water escape, but usually their fur is of sufficient value to insure their scarcity, if unlimited trapping is permitted.

Muskrats are expert swimmers, with large hind feet and fringed toes, a long, naked, sickle-shaped tail, and soft brown fur that nearly conceals the small ears. When full grown they weigh about two pounds.

\section{MEXICAN BEAVER}

\section{Castor canadensis mexicanus}

A few beavers are said to have been taken a few years ago in Black River on the Washington ranch, four miles south of the Carlsbad Cavern, but the foreman of the ranch thinks that none is found there now. During high water the Black River runs to the Pecos below Carlsbad, but for most of the year it is dry except in pools and sections where the water rises over rockyr dykes. On the Washington ranch there are large permanent pools and ponds, fed by flowing springs, so the beavers need only to swim up Black River from the Pecos in high water to find a paradise of deep water, high banks, abundance of food, and ideal homes. Evidently the Pecos River is used as a highway of travel by beavers, but the section below Carlsbad is very strongly alkaline and not enjoyed by them.

The beaver is a swimming animal, with fully webbed 
hind feet, a broad, flat, naked tail, and dense waterproof fur. Large individuals weigh as much as fifty pounds.

\section{BANNER-TAIL}

Dipodomys spectabilis baileyi (Figs. 28 and 29)

These large, long-tailed kangaroo rats with capacious cheek-pockets are abundant over the Pecos Valley and even on the high limestone ridges all around the Carlsbad Cavern. They keep to the sandy or gravelly soil where they can burrow and build their large mounds, and avoid the rocky ledges, cliffs, and caves. Over the valley their mounds are scattered irregularly, but often are so common that a dozen may be counted from one spot. Generally they are two to four feet high, and six to ten feet across, with several holes entering the sides and connecting with galleries which wind through the mound and deep into the earth below. The mound is built over and around the burrows with thin-walled partitions in such a way that a man or horse in walking over it may break through into the chambers below. They are carefully avoided by horses and riders as dangerous pitfalls, for they have caused the cowboys many a bad fall. Some of the mounds are built around a creosote or mesquite bush, the branches and roots of which give a good framework for strengthening the earth walls and protecting the house, for it is a real house, well built and perfectly planned for comfort and protection. Soft nests and ample stores occupy the underground chambers, which are all connected by 
galleries and inclined stairways. There are many rooms and feeding places where the chaff and refuse of food lie scattered on the floor until the accumulation becomes deep and troublesome, when it is carried out and mixed with the earth to increase the size of the mound. Most of the doorways and passages are generally closed with earth when the occupants retire for the day, a well planned protection against enemies and thieves that would prey upon their stores of food. Some of the doorways are usually left open, and the burrows to which they lead are often occupied by snakes, lizards, and other small animals, showing the wisdom of closed doors around the nests and storerooms.

To a great extent these kangaroo rats are solitary in habits, as all hoarding mammals are inclined to be, but in many of the mounds in April a male and female were taken, and on April 20 a half-grown young was taken at a mound near the cave. The breeding habits seem to be rather irregular and variable, probably depending on the weather and plant growth, which affects the food supply.

The animals are strictly nocturnal, and rarely have been seen alive by even the oldest settlers of the country, but owls and foxes prey upon them to a considerable extent, and they are easily caught in snap traps for specimens, or alive in tin can traps for study. A few were kept in my cabin while at the cave, but in separate rooms, as they would fight and kill each other if kept together. They were gentle and friendly with me, but did not like to be held or handled, nor to be disturbed 
in their warm nests during the daytime. Well after dark they come out of the burrows, and on the soft furry soles of the long hind feet go hopping noiselessly about in search of food, or skimming over the ground in flying leaps with surprising speed. The little front feet are used mainly as hands for gathering food, filling the capacious cheek pouches, and holding the small seeds and delicate plants that they eat. They are dainty feeders, rejecting all coarse parts, coatings, and shells of seeds, and selecting only the tender, juicy tips of growing plants, or the moisture-laden sprouts and bulbs, which supply the water necessary for a healthy desert life. Their systems are so perfectly adjusted to conserve moisture that a relatively small amount is required to supply their needs, and this they get from their food even in the most arid sections of our deserts where no visible water is to be found. Their underground and nocturnal habits also protect them from the extremely dry air of the desert climate and give them a comfortable and comparatively safe type of life.

The kangaroo rats are neither kangaroos nor rats, but a remarkable family of desert rodents, with external cheek pockets, long hind legs and tails, large heads and pretty buff and white markings. The white tip of the tail is a character of this species. 


\section{MERRIAM KANGAROO RAT}

\section{Dipodomys merriami merriami (Figs. 30 and 31)}

The little Merriam kangaroo rats are common over the valley and on the high limestone ridges about the Carlsbad Cave. They are probably as common as the larger species, but less conspicuous, as they place their burrows under bushes and cactuses,-spiny-leaved plants,-where they are often hidden or unnoticed. Many of the animals were caught, however, in traps set at various burrows, and not infrequently at the large burrows of the banner-tail which seems to have the same range, and on the stores of which they apparently depend for a share of their living. Both species were captured and kept in captivity in my cabin while I was at the cave. The big ones were always trying to jump on and kill the little fellows, which were, however, too quick and watchful to be caught. They were gentle, lovely pets, did not object to being handled, and usually were not unfriendly to each other. Five adults were often found sleeping in one nest box in my room, but occasionally there were nocturnal squabbles among them and some bloody tails next day. The one male in the group finally took up his quarters in a cotton roll on my desk and then the others were quiet and friendly. Usually they did not store up food for the daytime, but each filled its capacious cheek pouches with rolled oats and grain before retiring to the nest box for the day and so provided enough food to last until the following evening.

These little, four-toed kangaroo rats are about half 


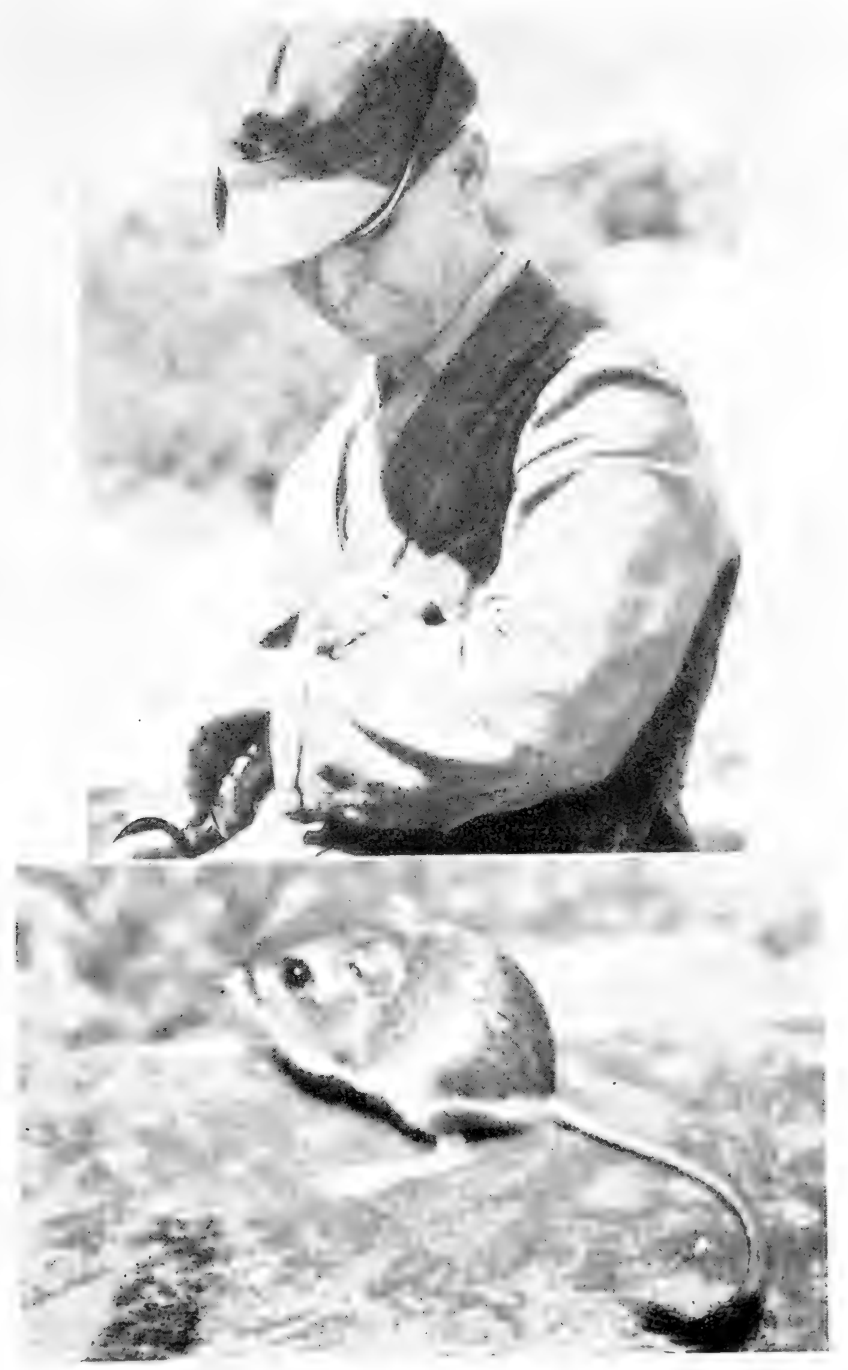

Figs. 30 and 31. Little Four-toes (Dipodomys merriami MERRIAMI)

The little four-toed kangaroo rats are common about the great Carlsbad Cavern, the gentlest, prettiest, and most interesting of all the small rodents of the region. 

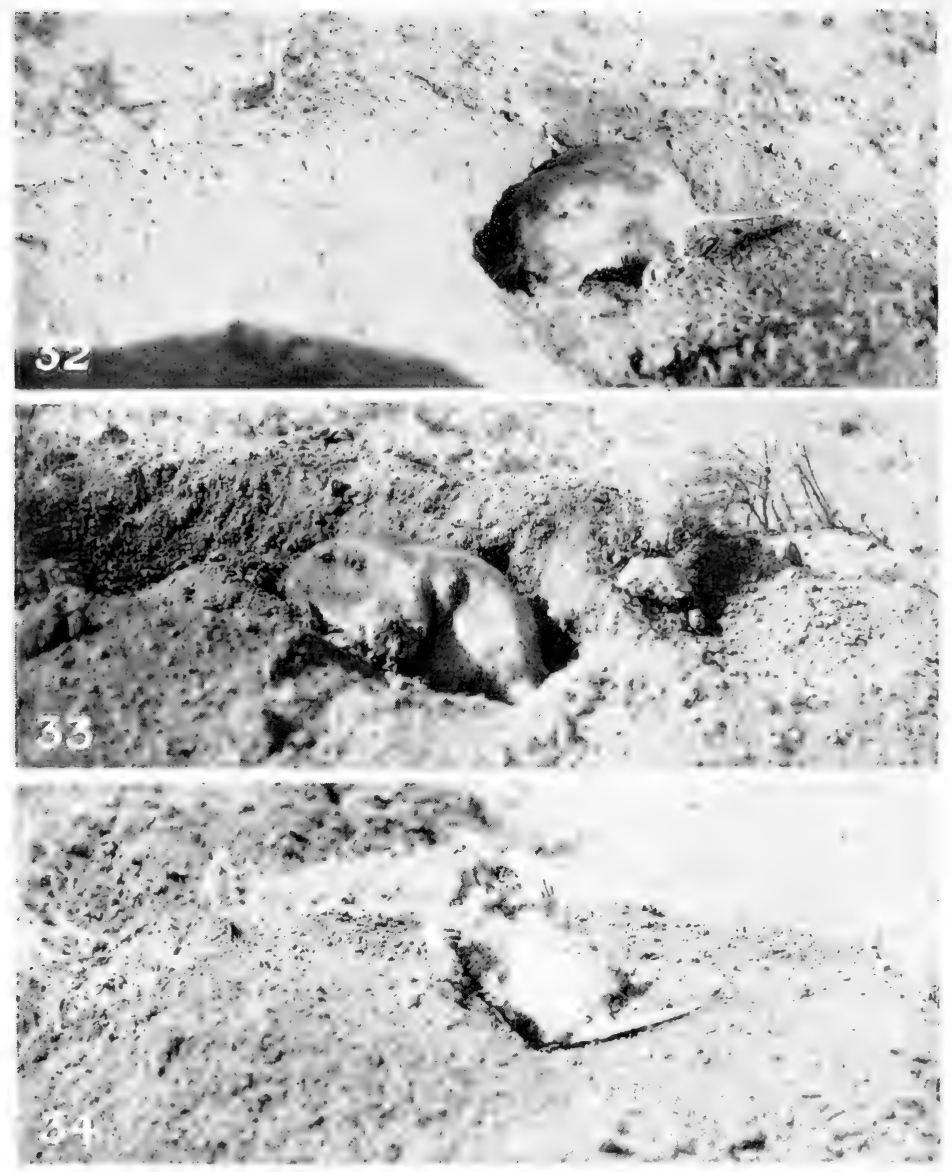

Figs. 32, 33, and 34. The Large Pocket Gopher (Cratogeomys CASTANOPS)

These big gophers live in the rich mellow soil of the Pecos Valley where they do great damage to crops and fruit trees, living almost their whole lives underground, feeding on roots or coming to the surface to stuff their large cheek pockets with green food to be carried into the burrow. 
the size of the banner-tails and lack the white tip to the long, slender tails. They are buffy brown, with white markings and white lower parts.

\section{POCKET MICE}

\section{Perognathus}

Pocket mice of three species are known from the Pecos Valley at Carlsbad, the large, coarse-haired Kansas pocket mouse (Perognathus hispidus paradoxus); the little, soft, yellow Dutcher pocket mouse (Perognathus merriami gilvus), originally described from Carlsbad specimens; and the tiny, yellow Baird pocket mouse (Perognathus flavus) of the Rio Grande Valley, which also comes up the Pecos Valley and has been collected at Carlsbad. None of these was taken in my traps near the cave, but jaws and parts of their skulls were found among the small bones under the owl nests at the cave entrance. There are still other species of the brush-tailed group of pocket mice that might occur here, but none of their bones was recognized.

All of these little pocket-bearing animals are desert dwellers, nocturnal burrowers of retiring, but very interesting, habits. Most of those studied were gentle and quite willing to be handled and stroked, even from the moment of capture, and they make unusually attractive pets. They are great storers of food and consequently rather inclined to be solitary in habits, and more or less greedy in robbing each other's stores, two of them often spending a whole night in stealing food from each other and hiding it in different corners of the cage. 
The large Kansas pocket mouse measures in total length about 222 millimeters; tail, $108 \mathrm{~mm}$; hind foot, $26 \mathrm{~mm}$.

The little Dutcher pocket mouse measures in total length about $118 \mathrm{~mm}$; tail, $58 \mathrm{~mm}$., foot, $16 \mathrm{~mm}$.

The tiny Baird pocket mouse measures in total length about $112 \mathrm{~mm}$.; tail, $50 \mathrm{~mm}$., foot, $15 \mathrm{~mm}$. All have fur-lined cheek pockets like the kangaroo rats.

\section{LECHUGUILLA POCKET GOPHER}

\section{Thomomys lachuguilla}

These small brown pocket gophers are fairly common all over the limestone ridges about the cave, and wherever the little century plant, mescal, or lechuguilla grows. They live almost entirely underground, even where the soil is so shallow over the limestone that they can not find enough mellow earth with which to close their doorways to the surface. Generally, however, their habitations are recognized by the numerous small mounds of dark earth pushed out along the lines of their tunnels, the earth covering and closing the temporary exits through which it was pushed out in the construction of the tunnels. The gophers live almost entirely among the little lechuguilla plants, upon which they largely depend for food, burrowing under and eating their way up into the rich food stored in the heart of the plant, and being protected from above by the bristling dagger points and hooked sawteeth of the rigid leaves. One of these large heads will supply good food and moisture for a gopher for probably a 
week, and a dense patch of the plants may keep one all summer with little extension of his burrows beyond their protecting spikes.

The plants are killed, of course, when thus eaten out, but fortunately the gophers are not sufficiently numerous to make much impression upon the miles of dense growth of this important food plant. The roots and bulbs and underground parts of many other plants are also eaten along the gopher burrows, but some returns are made to the plant economy by a constant stirring and pulverizing of the soil and by burying the surface vegetation under the gopher hills to decompose and return its richness to the earth.

This is a small gopher with the upper incisors ungrooved, and with large, fur-lined cheek-pockets, very small ears and eyes, and short, silky brown hair. The front claws are long but relatively slender.

\section{CHESTNUT POCKET GOPHER}

\section{Cratogeomys castanops (Figs. 32, 33, and 34).}

The big pocket gophers, with large, fur-lined cheek pouches are abundant on the mellow and fertile soils of the best farming land throughout the Pecos Valley. Even in the town of Carlsbad they are found in the bestkept lawns, and on vacant lots, and along the sandy border of the river. One that I caught in the dooryard of Carl Livingston's house in the heart of town had been burrowing for a year or more, covering much of the beautiful lawn with large unsightly mounds of clay. I found a trap set in the mouth of a hole that had not 
been opened half way down to the occupied tunnel, so dug down and reset it in the tunnel, where it caught the gopher in a few hours. None of these gophers was found nearer than four or five miles from the great cavern. Still I found many of their teeth and bones in the great horned owl pellets and on the earth beneath the owl nests in the mouth of the cavern. Under a nest near the Pecos River their bones were also numerous. Apparently these owls are one of the greatest enemies of the gopher, and therefore one of the best friends of the farmer, for the gophers are exceedingly destructive to farm crops and fruit trees. They eat the grain and alfalfa, cover growing crops with their large mounds, eat potatoes and most other garden vegetables, and injure or kill the fruit trees by gnawing the roots and bark from underground. Their eradication becomes necessary in cultivated grounds, but in waste places they do little harm and some good in stirring and enriching the soil.

These are the large valley gophers, about twice the size of the little lechuguilla gopher, with single-grooved upper incisors, and very heavy, front digging claws. They are buffy brown in color.

\section{JAGUAR}

\section{Felis hernandesii}

These great, spotted cats, leopard-like in appearance, but heavier and more powerful, live principally in Mexico and the countries to the south. Occasionally one comes over the border into Texas, New Mexico, or Arizona, and wanders over the rough. unoccupied 
country, killing cattle and game. There are some old and indefinite records of their occurrence in the Sacramento Mountain region, and Carl B. Livingston told me that about four years earlier (in 1920) a hunter brought a fresh skin of one into Carlsbad and sold it at one of the stores. He saw the skin but unfortunately did not learn just where the animal was killed, although probably it was at no great distance.

\section{GRAY MOUNTAIN LION}

Felis couguar aztecus

Mountain lions, also called panthers and cougars, have been in past years numerous and very troublesome to the stockmen of the Guadalupe Mountain region, but now are scarce and rarely found. A few still roam over the rough canyon country. One was killed in the mouth of the Carlsbad Cave a few years ago, and last winter another got into a coyote trap near the cave and carried it away on its foot. In April, 1924, in a branch of Walnut Canyon about four miles from the cave I found a dead colt, freshly killed and about one-fourtheaten, evidently by a cougar. Traps, dogs, and poison have so reduced these animals that they are almost harmless. A few may be considered desirable as affording some spice of large carnivore life to the country. Just the thought that one might see a big, long-tailed, yellow cat out in the hills is worth something.

The numerous caves have been not only strongholds for these cats, but in some cases have doubtless served 
as traps where large game could be cornered and captured. It would seem an easy matter for them to catch mountain sheep in the cave in Slaughter Canyon, but with a fair start from their rocky bed-ground the sheep would have a good chance to escape through the great cave door, out onto rough slopes where they would be safe.

The gray mountain lion is merely a pale desert form, less deeply tawny than that of the Rocky Mountain region.

\section{MOUNTAIN BOBCAT}

\section{Lynx rufus uinta}

No bobcats were seen near the cavern, and they seem to be scarce at the present time, although they have been one of the commonest of fur bearers in past years in all the canyons, cliffs, and caves of the region. The foreman of Washington's ranch, four miles south of the cave, told me that they had killed seven during the winter, hunting them with dogs. Traps and poison have also helped to thin their numbers. Jim White has seen them in the west opening of the big cave, where they might find ideal homes among the rocks of the entrance as well as in the dark tunnel below. I found no trace of them inside the cavern and doubt if they ever followed it for any considerable distance.

The bobcat is a short-tailed, long-whiskered, tasseleared cat, that sometimes reaches a weight of twentyfive or thirty pounds. It is yellowish gray, much spotted with black on sides, throat, legs, and belly. 


\section{Urocyon cinereoargenteus scottii}

Gray foxes (frontispiece), once numerous in this cave region, like all of the small carnivores are now scarce, doubtless owing to widespread poisoning of the range. One old carcass was all that we found near the Carlsbad Cavern, but a few tracks were seen in Slaughter Canyon. These foxes are said to be more common in the mountains, where the sweet berries of the checkerbarked juniper are abundant, and where the pine nuts help to supply them with food.

Not being very swift of foot they depend largely upon rocks and small caves for cover and refuge, and when pressed by dogs will climb to the tops of trees and hide among the branches. Their climbing habits may well have been developed by their fondness for the berries and sweet fruit of junipers and other trees.

The gray fox is smaller than the red fox and not so swift. It has a flattened tail, with black tip, and rather coarse gray fur with bright orange brown on throat, sides, and legs.

\section{TEXAS COYOTE}

\section{Canis latrans texensis}

Coyotes are not abundant in the cave region, but a few follow the trails up the ridges and canyons from the valley below where they hang around the stock ranches, follow the herds of Angora goats, and catch jack rabbits for a part of their living. At the cavern they were occasionally heard howling at night, with long yap, yap, 


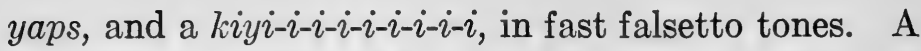
few bones were found back in the cavern a hundred feet beyond the great western doorway, where they may have been carried, or where some coyote cornered in the entrance and forced to jump into the cave had died a lonesome death. Poisons and traps have thinned them out in this part of the valley, but Carl Livingston told me that they were more numerous east of Carlsbad, where on one large cattle ranch they were known to have killed about twenty calves in the spring of 1924 .

The coyote is a small wolf, less than half the size of the lobo, weighing about twenty-five or thirty pounds, dark yellowish gray in color, and with rather large ears.

\section{GRAY WOLF}

\section{Canis mexicanus nubilus}

These big gray wolves, or lobos, were once numerous in the Pecos Valley, and were still very destructive to stock when I was there in 1901. Now they are practically gone, and the stockmen could give me no recent record of their occurrence in the Carlsbad region. A few may wander in from time to time from across the Rio Grande or other areas where they have not been systematically trapped.

The large gray wolf or lobo of the Mexicans is a heavy animal, of ten weighing over one hundred pounds, with long, light gray fur, and a well marked cape or mane of long hairs. 


\section{NEW MEXICO BRIDLED WEASEL}

\section{Mustela frenata neomexicana}

The bridled weasels are such pretty animals that if once seen they can not be mistaken for any other weasels. Jim White told me that he had several times seen them and had caught some in traps near the cave, and on a fresh fall of snow about the middle of March I saw the unmistakable track of a weasel in the great pit at the west entrance to the cave. Never abundant anywhere, these interesting animals are evidently not uncommon here, and hunt the cave walls for mice and other small game.

The bridled weasels may be known by the dark face and white spot on the forehead, the long, slender, light brown body, and black tip to the long tail.

\section{LONG-TAILED TEXAS SKUNK}

Mephitis mesomelas varians (Fig. 35)

The common skunk occurs more or less generally in all the canyons and gulches of the cave region, and at times is known to enter the cave openings. One caught in a goat corral, where it had been digging for beetle larvae in the goat manure, was coaxed into a tin can, carried to camp, and given a dose of ether by merely pouring a couple of ounces of the fluid into the tin can. In about two minutes, while limp and helpless so that it could be safely handled, the skunk was placed on the ground out in the sunshine, and when it had recovered from the anaesthetic, was photographed several times before it was allowed to escape. 
The long-tailed skunk has two broad white stripes along the sides of the back, meeting over the neck and shoulders and on the sides of the tail, and a narrow white stripe down the face; the rest of the body is shiny black; the odor is as strong and characteristic as the color and pattern.

\section{HOG-NOSED SKUNK}

\section{Conepatus mesoleucus mearnsi (Fig. 36)}

A fine old male of this big species, with long nose, solid white back, and bushy white tail, was taken at an old goat camp in Walnut Canyon, a mile and a half from the cavern. It had been digging deep holes in the old manure of the goat corral in search of big fat "grub-worms," larvae of a Lachnosterna beetle, which were the only food found in its alimentary canal. The large round beetle burrows leading straight down into the manure were the size of my finger, and with the help of his long bare nose the skunk could probably tell before he began to dig whether a fat grub was to be found at the bottom. Most of the burrows went down about a foot, and I learned by digging that the beetle larvae were common at this depth. The skunk taken was only moderately fat, but weighed nine pounds, a weight not equaled by any of the other skunks unless excessively fat. It was coaxed into a joint of stovepipe, given a dose of ether, and photographed while under the effects and after it had partly recovered; but when fully recovered and closely pursued, it discharged its powerfully repellent battery so vigorously that 

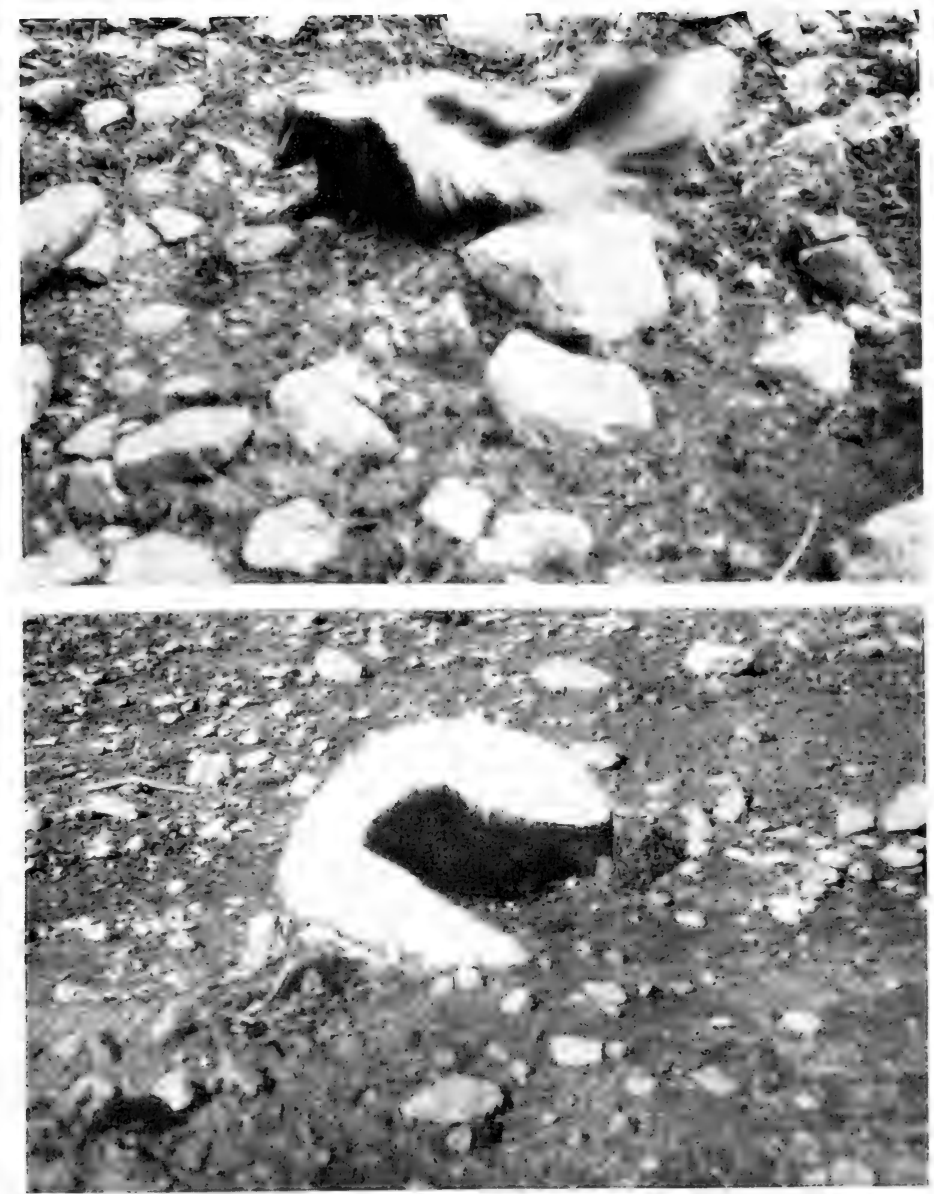

Upper: Fig. 35. Texas SkUNK (Mephitis mesomelas varians)

Reviving after a thorough anaesthetic but not yet vigorously active.

Lower: Fig. 36. Hog-nosed Skunk (Conepatus mesoleucus MEARNSI)

Given a dose of ether and photographed hurriedly as he became active again. 

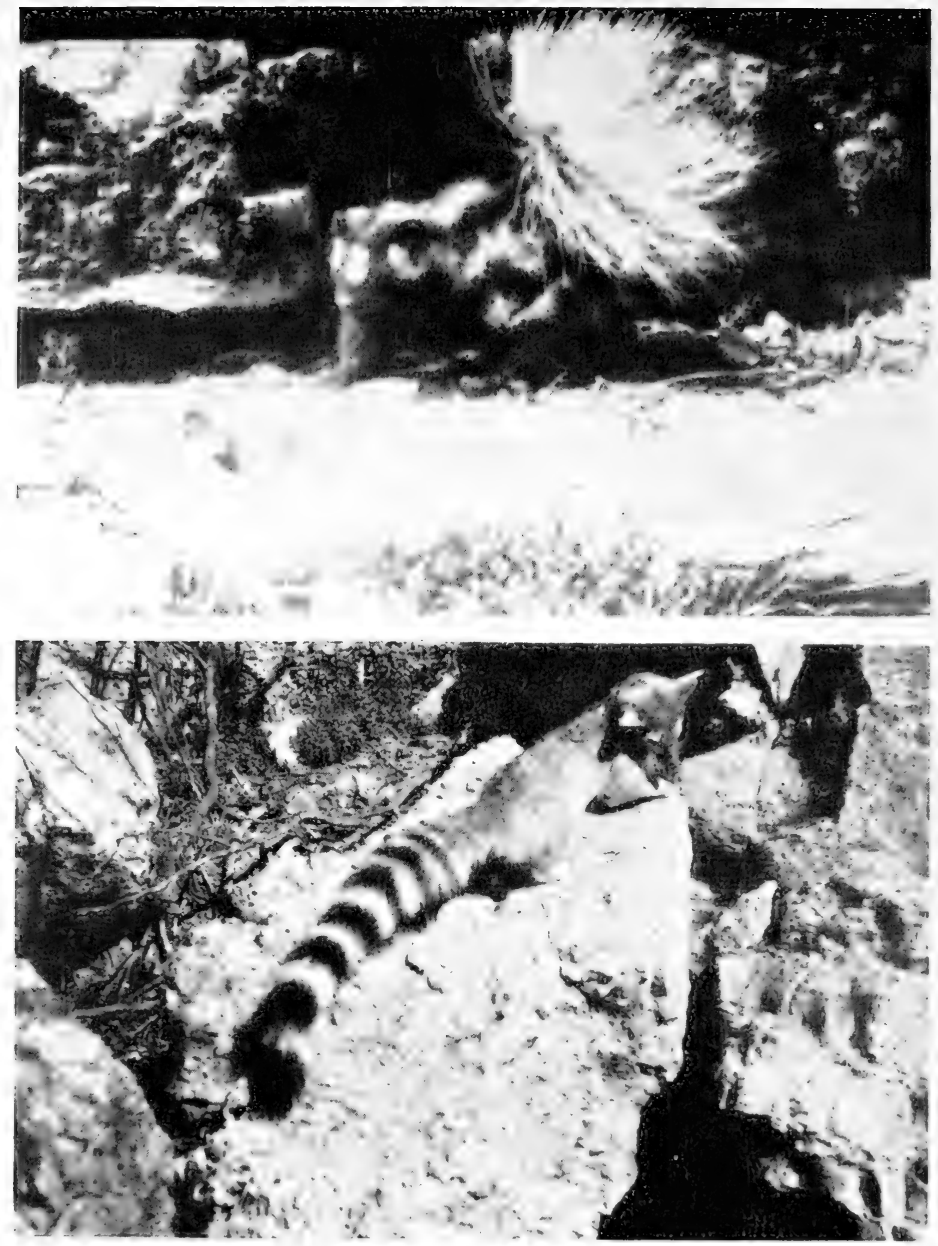

Upper: Fig. 37. Little Spotted Skunk (Spilogale leucoparia) Captured at the doorway of the Carlsbad Cavern

Lower: Fig. 38. The Ring-tailed Cat (Bassariscus astutus FLAVUS)

These beautiful, soft-furred cave-dwellers are skillful climbers over cliffs and rocky walls where the large squirrel-like tails serve a useful purpose. 
further efforts at photography were abandoned. The odor of these big skunks differs but little from that of the common Mephitis, but the fluid appears to be more copious and more powerfully ejected.

The hog-nosed skunk is the largest of the three genera of skunks, with naked nose pad, very long digging claws, and a solid white back and tail.

\section{LITTLE RIO GRANDE SPOTTED SKUNK}

Spilogale leucoparia (Fig. 37)

These graceful, weasel-like, little skunks, with their dazzling pattern of black and white spots, and stripes and zigzag lines, their plumy tails and intelligent faces, are the most attractive of the skunk tribe. They are common in the caves and in crevices of the cliffs, or under broken rocks wherever food and cover are to be found. They are great climbers over cliffs and rocks, as well as in bushes and trees, and seem to delight in prowling through the dark recesses of caverns or following the narrow shelves of cliffs and canyon walls, where their little tracks are often found in the dust. At the mouth of the great cave one was caught in a wood-rat trap under a hollow ledge where the wood rats lived. As it was not injured, it was kept alive during my stay at the cave and occupied a cage in my sleeping room for several weeks. It soon became fairly gentle and would take food, very cautiously, from my hand. On two occasions it escaped from the box at night and went pattering around the floor, creating great excitement among my other small animals, running loose in 
the room until I got up and shooed it back into its nest box and fastened the door. On one of these occasions it caught and killed two of my little kangaroo rats before they discovered its presence, but the others kept well out of reach around the room. In the cage it ate the bodies of birds and small mammals that had been skinned for specimens, as well as cooked meat, bread, and fruit, but a large part of the natural food of this species consists of insects, and mice and other small rodents. Another spotted skunk, which lived in a storehouse near the cave shaft, caught or drove out all the wood rats and mice that had been living there.

By many of the western people these little animals are called "hydrophobia cats," or for brevity "phobycats," and their bite is believed invariably to convey rabies. This is not the case, however, as their bite is normally followed by no serious consequences, although, if they were suffering from rabies, their bite would convey the disease in the same way as that of a dog, cat, or other infected animal.

The little spotted skunk is about half the size of the common skunk, black, strikingly striped and spotted with white, and with the long brush of the tail all white. Its odor is but little different from that of its larger relatives.

\section{MEXICAN BADGER}

\section{Taxidea berlandieri}

Badgers are fairly common in the valley country, but rarely come up on the rocky ridges about the cave. Their large burrows are especially common in prairie- 
dog towns, where these fat little squirrels have been dug out for food. They also dig out many ground squirrels, kangaroo rats, and mice, getting most of their living by the aid of their long, powerful claws backed by heavy digging muscles. With short legs they have little chance to escape from their enemies, unless a burrow is near enough for refuge, but once the burrow is gained they defy all further pursuit. When escape is cut off, however, they will stand their ground and fight savagely with any opponent. Their thick hides and keen-cutting teeth render them no mean antagonist for the largest dog, and they usually get away with less injury than any dog so rash as to attack them. Men and boys, however, can rarely resist the temptation to shoot so large and conspicuous an animal, even though practically harmless and one of the most useful of our native animals. On very rare occasions one may get into a hen-house and kill all the poultry it can find, but this is easily preventable and should be given little weight against the enormous destruction of prairiedogs and ground squirrels, the most injurious of rodent pests, carried on industriously throughout the year by the badgers. The old excuse for killing badgers, that horses stepped in their burrows and broke their legs and the necks of the riders, is no longer valid, as the days of the cowboy are over. Fat cattle, barbed wire fences, and automobiles have superseded them.

The badger is a low, wide, heavy-bodied animal about the size of the raccoon, but with short legs, short tail, and very long, powerful digging claws. It has coarse gray fur, with black face markings, and a narrow white line along the middle of face and back. 


\section{TEXAS GRIZZLY}

\section{Ursus texensis texensis}

That grizzly bears once inhabited the Sacramento and Guadalupe mountain ranges is well known, but as early as 1900 they were extremely scarce, and now are probably all gone. Not a specimen remains to show what the species was, but on grounds of proximity they may well have been the same as the one described by Dr. C. Hart Merriam from the Davis Mountains, Texas, killed in 1900 by C. O. Finley and John Z. Means. Apparently the species is now extinct, but any old skulls from the Guadalupe or Sacramento mountains would be of great interest in showing which of the several species of grizzly bears once inhabiting New Mexico was represented in this range.

This is a small brown or gray form of the largetoothed, long-clawed, grizzly group.

\section{NEW MEXICO BLACK BEAR \\ Ursus americanus amblyceps}

A few black bears still occur in the Guadalupe Mountains, and occasionally they come down the canyons almost to the great cave. Originally they undoubtedly came beyond the cave, and may at times have occupied the entrance tunnel, as they still sometimes do in the caves in Slaughter and other canyons. The dense chaparral in the heads of canyons of the Guadalupe Mountains affords excellent cover and an abundance of acorns and berries for bears in a region so steep and rough that hunting is difficult, and it is to 
be hoped that some will remain here for many years to come.

The black and brown bears of this region are readily distinguished from the brown grizzlies by the short, sharp, front claws, and the relatively small teeth.

\section{MEXICAN RACCOON \\ Procyon lolor mexicanus}

Raccoons find an abundance of food and congenial range along the Pecos and Black rivers, but rarely come up to the vicinity of the great cavern. Two were killed last winter on Washington's Ranch on Black River just south of the cave, and tracks of others were seen in the mud along the Pecos in April. They often live in caves or holes in the cliffs, but rarely go any great distance from open water.

The Mexican raccoon is very similar to the eastern form, but generally clearer gray in color, with the same black mask across the eyes, and five black rings around the furry tail.

\section{RING-TAILED CAVE CAT}

Bassariscus astutus flavus (Fig. 38)

Of the few mammals that reach to the farthest ends of the deepest and darkest halls of the great Carlsbad Cavern and inhabit all the other numerous caves of the region, the "ring-tail," as locally called, is the most spectacular and interesting. This representative of the raccoon family comes into the southwestern United States from Mexico, and with several varieties or sub- 
species extends from the Pecos River to the Pacific Coast and northward to southern Oregon. It is about the size of a small house cat, with a strikingly barred or ringed tail, longer and larger than the rest of the animal, and with a fox-like face and cat-like feet. It is well known to prospectors and trappers of the region, but its plain gray fur, while soft and fine, has little value in commerce and is rarely seen in actual use. To the prospector the animals are of special interest, as they often visit his cabin and catch the surplus mice and rats, and in some cases become so tame as to make interesting pets. In the great cave their tracks and bones were found in several of the largest rooms, the most numerous and freshest tracks being found in the farthest and deepest room of all, to which we descended from the floor of the large south room by a hundredfoot wire ladder. Later Carl Livingston reported one seen alive in this room. An almost complete skeleton was found in the south room, and other parts of skeletons were found near the entrance to this room and on both sides of the Devil's Den; much old excrement was observed on the guano-covered shelves of the large bat room back of the west entrance to the cave. Poison and traps had recently destroyed most of the animals outside, but one visited the west entrance to the cave several times during my stay and left his cat-like tracks on the dusty floor of the arched doorway and along the narrow shelf that runs past the little drinking pool and around the limestone wall to the various niches where cliff mice and wood rats live. Some of these cliff trails are little more than creases in the sheer 
wall where claw holds might well require the balance of a long and spreading tail; or long leaps from point to point a squirrel-like rudder; for the flattened tail is more squirrel-like than cat- or raccoon-like.

To obtain specimens I went to the smaller caves in Walnut and Slaughter canyons, where the ring-tails were more numerous, and in one of the caves, high up on the side of the mountain and not easily reached, they were so numerous that trails and fresh tracks led into every nook and corner, and especially into the small tunnels where no larger animal could follow, and where there were evidently well protected breeding dens.

The animals are rarely seen except when caught in traps. They follow the cliffs and canyon walls from one cave to another, and undoubtedly make journeys from one canyon to another, but in most places caves are their real homes. They are strictly nocturnal, and their large eyes are well adapted to night use, but how they find their way about and catch their prey in the utter darkness of the deeper caves are unsolved mysteries.

They are hunters, but their food is varied to include almost any small animal life, mammals, birds, insects, centipedes, and fruit. The pellets of old dried excrement from the inner shelves of the cave showed a mixture of bones, fur, feathers, and insect shells, remains of cave mice, wood rats, guano bats, cave crickets, and other insects. In some cases the bones and fur showed their food to have consisted entirely of guano bats, and these must have been caught as they crowded out or in the cave doorway during periods of great abundance. 
Except for this destruction of bats, which would occur only where large colonies gather, their food habits are largely beneficial in controlling the abundance of rodent and insect pests.

The ring-tail is most nearly related to the raccoon, but is much smaller and slenderer, with a bright pretty face and large ears, a long flattened, bushy tail with six or seven black bars across the top, and buffy gray fur over the body.

\section{MEXICAN FREE-TAILED BAT}

\section{Tadarida mexicana mexicana (Figs. 39 and 40)}

The bats of the Carlsbad Cave are not the so-called cave bats of recent literature, but the free-tailed bats, the famous guano-producing species of Mexico and the southern United States, and more than any other group of bats, cave dwellers. They differ from our northern bats in the projecting tail, reaching about aninch beyond the attached membrane, in the short, wide ears, short fur, and in a strong odor peculiar to the group. Their habit of roosting in extensive colonies in caves or buildings has given them great value in the production of guano, much prized as a fertilizer. These are not the only bats found in the cave, but they are present in such numbers that other species are little noticed.

The number of bats in the cave varies at different seasons, apparently reaching the maximum in August and September, when they gather for their winter sleep. They hang themselves up under the highest dome of the cave ceiling, one hundred fifty feet above the cave 

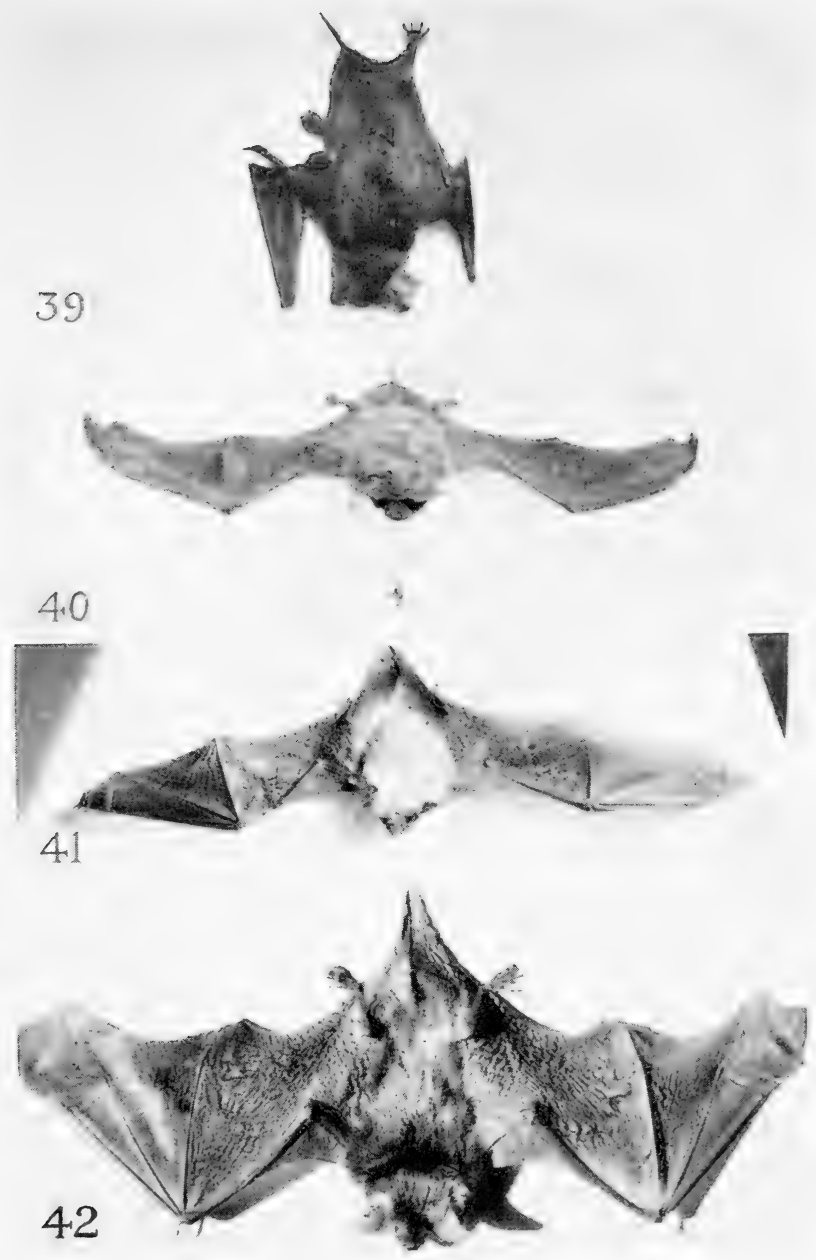

Upper Two: Figs. 39 and 40. Guano Bat (Tadarida mexicana MEXICANA)

One alive and crawling backwards up a cloth curtain, the other dead and spread on glass in form of flight.

Third: Fig. 41. Little Cayyon Bat (Pipistrellus hesperus) Lowest: Fig. 42. The House Bat (Myotis incautus) 

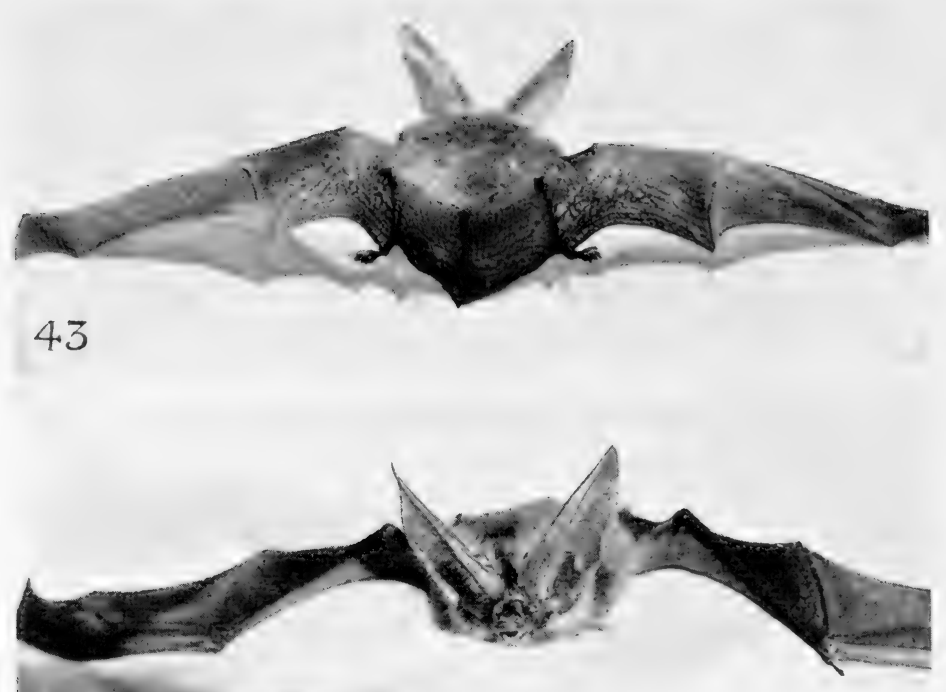

\section{4}

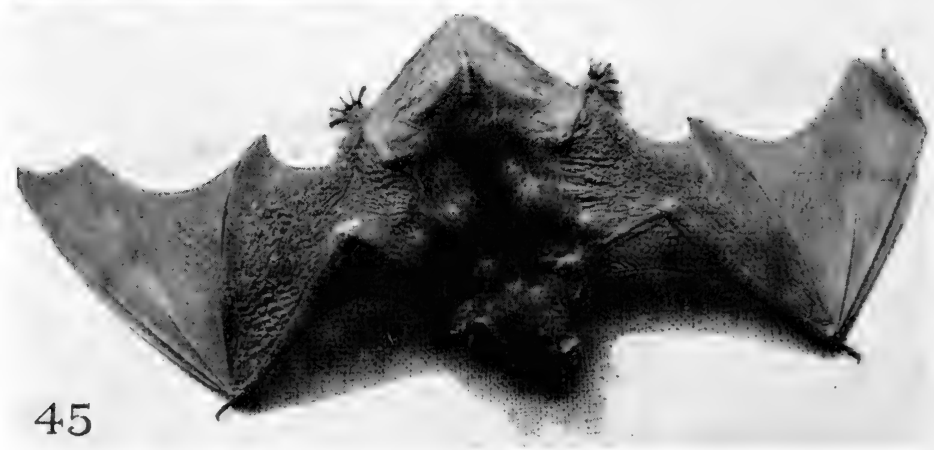

Upper Two: Figs. 43 and 44. Jack-Rabiti Bat (Corynorhinus MACROTIS PALLESCENS)

One of the longest-eared bats of North America

Lowest: Fig. 45. Big Brown Bat (Eptesicus fuscus fuscus) 
floor, where they can barely be seen by a powerful searchlight, and are entirely out of reach of ladders, so the estimates of numbers must be based on their flights to and from the cave. On my arrival at the cave, March 11, they were quiet, and most of them apparently were still in the torpor of hibernation. A few days later, on warm evenings, they began to come out of the west entrance in considerable numbers and disappeared in the darkness of the night. At first about one thousand were estimated as leaving the cave during the twilight hour, but later the numbers increased until on May 5 about twelve thousand (partly counted and partly estimated) came out in one hour, from 7:10 to 8:10 p.m., mountain time. The following morning they reëntered the cave before daylight, at 4:00 to 4:45 a.m., or up to twenty-five minutes before sunrise. Each morning they returned and entered the cave apparently in considerably less numbers than those leaving the night before. Undoubtedly many scattered out at this season over the low country, where insect life had become abundant, and where comfortable shelter could be found near the source of food supply. All evidence points to the fact that the Carlsbad Cavern is mainly a wintering place for these bats, where they pass the winter in a state of torpor.

In late summer and early fall the bats are said to gather at the cave in enormous numbers. For several hours in the evening they pour from the openings in black streams so dense that they can be seen from a distance of two miles, and fill the shafts so closely that they can be caught in the hands as they pass out. 
Their numbers must thus run into the hundreds of thousands or into millions, and such numbers would be necessary to account for the great deposits of guano once found in the cave. It is well known that in the fall these bats leave buildings and any quarters exposed to low temperatures and return again in spring.

Hibernation, or the complete torpor in which the temperature of the animals' bodies becomes approximately that of the air, and all the life processes are reduced to the lowest stage that will maintain life, is probably continuous with the bats for about five months, from October to March, but more or less intermittent in fall and spring. On my arrival at the cave, March 11, some of the bats came out on warm evenings, and at least a part of them returned in the morning, but a series of cold nights kept them in for a week or more at a time. A few would be found flying about in the cave during the evening, but only a comparatively small number, and these would not go out into the cold outer air. The air at the bottom of the room under the bats was usually 55 degrees Fahrenheit during March and April, and is said to vary but little throughout the year. Unfortunately, the hibernating colonies of bats in the cave were so far out of reach that a satisfactory study of temperatures and conditions could not be made.

The bats captured and kept in captivity became torpid at night when the temperature fell to 50 degrees Fahrenheit, and showed about the same body temperature as the air. They were stiff and unconscious, able only slowly to move a foot or wing when disturbed, or 
when they began to warm up. At 60 degrees they became active, and usually remained so during the day in my room.

While the bats were hibernating, their stomachs and the whole alimentary canals were empty, no guano being deposited during the winter rest. However, after a warm night in spring when the bats had come in and hung themselves up for the day, there was constant dropping from above of the little dry pellets of excrement.

The guano deposits in the cave have been enormous; they were one hundred or more feet in width, a quarter of a mile in length, and varied up to a hundred feet in depth. Back beyond all traces of light no live bats were found, and there were no extensive deposits of guano and only a thin layer of scattered droppings in places where bat bones were found. Most of the guano in the cave was removed during the twenty years between 1901 and 1921, and shipped away for fertilizer. Jim White, who had charge of getting out the guano, estimated that during about fifteen years approximately half of each year was devoted to the work, generally from September to March, and that from one to three car loads of guano weighing about forty tons each were shipped each day. A maximum of three car loads a day was shipped at rush times only, but even one car load a day for seven years would amount to considerably over one hundred thousand tons of guano taken out of the cave. From twenty to forty men were employed at a time, sacking, elevating, and hauling the guano to the railroad, and night and day shifts were 
worked in the cave. Two men working together could fill and tie up four hundred sacks a day, the sacks weighing 50 pounds each, and these were lifted to the surface with engine and cable and loaded on heavy wagons for the twenty-two-mile haul to Carlsbad.

The guano was shipped to the General Fertilizer Company of California, but I could get only a general statement of prices ranging from twenty to eighty dollars a ton. Of course the returns were not all profit, but the cave was considered a valuable property until the store of guano was practically exhausted. The lower levels were very old, and not so rich in nitrates nor so valuable as the more recent deposits.

At the present time there is little guano in the cave, probably not a dozen car loads, and it is being deposited so slowly that it can not have a real value again for many years. A layer of about three inches in depth has been added since the work stopped four years ago. Under the central part of the bat roost, on April 29, 1924, I spread a paper twenty by thirty inches, and in 44 hours caught 1,145 of the bat droppings, each about the size of a grain of wheat and all together weighing 5 grams when fresh, and 3.7 grams when dry. The paper was about half-covered, so that a single layer about two millimeters, or a twelfth of an inch, deep would at this season require about 88 hours or nearly four days for deposit.

But insect life was scarce at this season, and bats taken as they entered the cave in the morning had their stomachs not more than half-filled, while those leaving at night showed empty stomachs and often the 
whole alimentary canal empty. This would indicate unusual scarcity of food and a correspondingly light deposit of guano. Bats are normally hearty feeders, and some are known to eat a quarter of their own weight of insects at a meal, and probably half their weight or more during a night. They also drink heartily when they first start out in the evening, flying to some pool or open water and dipping repeatedly to the surface, scooping up mouthfuls of water while skimming close to the surface on widespread wings.

Food is probably the determining factor in the abundance and distribution of these bats, as they are said to be more numerous some years than others, most so in rainy years when insect life is abundant. Evidently they move to find a satisfactory food supply, or leave an area deficient in insect life.

The details of their food habits are not well known, as their teeth, with intricate cutting crowns, cut the insects into minute particles. All of our United States bats are known to feed entirely on insects, mainly caught on the wing, but the kinds of insects in the stomachs or composing the little dry droppings are necessarily determined with great difficulty. Samples of the guano from the cave proved under the microscope to consist largely of remains of numerous species of beetles and moths with occasionally recognizable bits of wings, legs, or other remains of flies and other insects. Bats shot while feeding at dusk sometimes have recognizable insects in their mouths, but the relative proportions of species eaten have never been determined. Small, soft insects, such as mosquitoes, are rarely, if ever, recognizable. 
Where the bats were feeding could not be learned, as they did not remain about the cave at night, and could not be found along Black River, nor at any of the springs in the canyons. They probably went to the Pecos River or Carlsbad, where insect life was more abundant. Those taken on my arrival at the cave were still well supplied with a layer of the winter fat under the skin, but later this had mostly disappeared, showing that food had been scarce since they awoke from the winter's sleep.

The free-tailed bats are more gregarious than any other species, and perhaps for this reason they occupy only certain caves. None was found in any of the nine other caves of the region entered. However, they undoubtedly occur in some of those that we did not enter where considerable guano has been taken out in past years.

On the wing these bats are strong, rapid flyers, and will even breast a stiff wind in returning to the cave in the morning, rising and falling to take advantage of the air currents, and often coming down into the cave from high in the air with whistling, shrieking wings as they drop, zigzaging through the air, checking their speed at every turn. In coming out of the cave the rumble of their wings sounds like the muffled roar of a rapid river, interspersed with sharp clicking sounds made by overlapping wing-tips striking together as they crowd through the great doorway and swarm up into the evening air. They are wonderfully skillful at dodging and avoiding objects, and their flight is so swift and crooked that few specimens were obtained 
with the shotgun. With nets on long poles it was an easy matter to sweep them in from the air as they crowded out of the cave doorway in the evening, and we thus obtained all that were needed for examination and study.

It was interesting to note their methods of progress in captivity. They would climb rapidly up a cloth or wire mesh, reaching up with long hooked arms, and drawing up the body first on one side and then on the other, and then turning around would hang themselves up by the hooked claws of the hind feet to rest or sleep. On the ground or rocks they would run rapidly on all fours, crawling into dark corners to hide, or launching off on spread wings from the edge of a rock or even from the ground.

These bats have few enemies, and the fact that they prcduce but one young a year would indicate either long life or unusual immunity from accidents. Where massed together as they are in this cave, however, they are captured and eaten to some extent by the big cavedwelling owls, the ring-tails, and quite probably by other predatory animals, such as foxes, coyotes, and bobcats. Jim White told me that one year when his old cat had kittens she would go to the cave shaft in the evening and catch the bats as they came near the edge or fell to the ground and carry them to her kittens to be eaten. When the bats were most numerous, he has seen her with two in her mouth and a foot on each of two others looking around to see what to do next.

Bat bones are abundant in places back in the farthest recesses of the cave, generally, with a little old guano 
scattered about. Most of these bones are in halfhidden corners or little niches in the wall, as if the bats had become unable to rise from the floor from weakness, and had crawled into some corner to die. Many of the skulls show the worn-out teeth of old age, or young bats just able to fly, but others in the prime of life may have become poor and weak from lack of proper food and adverse weather conditions, and so were unable to make the steep aerial climb out of the shafts of the cave. In other caves the same conditions have been noted, large numbers of dead bats being gathered in certain places in the far corners of the cave bottom, where they have been reduced to skeletons and may have been preserved for a long time. A few mummies of bats with matted fur still clinging to crumbling skin were also found with the bare bones or scattered here and there over the cave floors.

If the natural life of a bat were ten years, from a colony of a million there would be about a hundred thousand die of old age each year, so it is not strange that thousands of skeletons are to be found in places where there is nothing to destroy the animals.

The free-tailed, like most other species of bats, has but one young a year, born in May or June. Mating probably takes place in July or August, but the reproductive process is retarded during the period of hibernation. The first bats taken at the cave in March were all males, but females first taken as they came out on April 24 contained embryos seven millimeters in diameter, or about the size of a number 6 buckshot. On May 9, the egg-like embryonic sack was $11 \mathrm{~mm}$. in 
diameter; on May 22, $15 \mathrm{~mm}$. in diameter; and on June 13, 22 by $17 \mathrm{~mm}$. in long and short diameters. At the last mentioned time the young was practically ready for birth and weighed 3.6 grams, while the mother weighed 13.6 grams, or approximately four times as much as the foetus. The birth of these young, fully a quarter as heavy as the mother, would not be possible but for the open, low, and widely separated pelvic bones of the female bat. Even then it is scarcely conceivable that she could give birth to so large a young one, comparable to a 35-pound child of a human parent.

After birth the young bats cling to the mother and are carried about even while she is on the wing in pursuit of her insect food. Her two nipples are conveniently placed on the sides of her breast well around under the wings, and as the mother hangs head downward during the day, the young are cradled in the armpits just below the nipples. Whether the young are carried until old enough to fly and catch their own food is not well known, but they develop rapidly and begin to fly before they are full-grown. But much remains to be learned of the breeding habits of all bats.

The general attitude that bats are "horrid," "vile," "venomous," "emblems of the infernal regions," and that "they get into your hair" is mere folk lore, based on ignorance and passed on from generation to generation. To most people a bat is a bat, and they have no realization that there are numerous families and genera and species, differing as widely as do the species in any other order of mammals, and perhaps more widely, and that they belong to one of the most highly specialized 
groups of mammals on earth, and perhaps are among the oldest. In North America there are approximately eight families, seventy-three genera, and two hundred and fifty species of bats. The number of individuals is enormous, corresponding well with the numbers of birds, and these are scattered over the continent partly in accordance with the insect population, or with certain groups of insects, on which they largely subsist. Naturally the number of species and individuals is greater in the south than in the north.

All of our North American bats, north of the tropics, are entirely insectivorous, feeding on nocturnal insects and to an important degree controlling their abundance, just as many birds do the diurnal insects. It is conceivable that without bats many kinds of vegetation would be wholly devoured by insect pests, just as without the birds our crops and forests would suffer. It seems not unreasonable to credit bats with an economic value to man approximately equal to that of the birds.

The guano bats belong to a southern group, with tails extending about an inch beyond the membrane, with short, wide ears, close, oily fur of a sooty color, and with a strong odor that is unmistakable. They are of medium size, spreading about twelve inches across the wings.

\section{JACK-RABBIT BAT}

Corynorhinus macrotis pallescens (Figs. 43 and 44)

These long-eared bats were found in the McKittrick Cave, twenty miles west of Carlsbad, on April 15, still hibernating, hanging cold and torpid to the roof of the 
cave, with ears curled around their heads like the horns of old rams. A number were captured and taken to camp and kept for many days in my room. They would become active during the warm part of the day, but cold and torpid again at night, and roll up their ears in spirals on the sides of their heads. Specimens were saved and photographs taken. The cave is low and comparatively dry and warm.

These large bats may be known by the long, pointed ears, light brown fur, and wide wings, spreading about twelve inches.

\section{BIG PALE BAT}

\section{Antrozous pallidus}

These big pale bats were not found alive at or near the Carlsbad Cavern, but several of their wing bones, including three humerus bones easily recognizable, were found in the farthest, deepest room of the cave. They were old and bleached, and had been there many years. The bodies of several dozen were found in a water tank in Slaughter Canyon, where in drinking from the surface of the water they had struck the galvanized iron walls, and had fallen in and were drowned. The tank was some forty feet wide and six feet high, and less than half full of water. These were the only bats found in the water although Eptesicus fuscus and other smaller bats came to drink from the tank in great numbers.

Big pale bats are still larger than the jack-rabbit bats, with ears almost as long, but broadly rounded at the tips. Their fur is light buffy gray. 


\section{BIG BROWN BAT}

Eptesicus fuscus (Fig. 45)

These large brown bats, weighing twelve grams, were the commonest and the only kind shot in Slaughter Canyon as they came to the water tank in the evening to drink. Others seen flying at the spring and at the entrance of the cavern may have been the same, but none was taken near there. A couple of old skulls picked up on the floor of the far south end of the lowest room of the cavern prove to be of this species, and strongly suggest an opening at that end where they could have entered without going the whole length of the dark corridors.

These medium large, dark brown bats can often be recognized on the wing by their size, color, and strong rapid flight. The spread is about thirteen inches across extended wings.

\section{SILVER BAT}

\section{Lasionycteris noctivagans}

One of these black, woolly bats, with frosted back, was shot at the spring the evening of April 12, by Dana Lee, and two others were seen flying along the wall of W'alnut Canyon a few days later in the early evening. The one collected measured 275 millimeters across the wings, and weighed eight grams. They are northern bats, breeding in the higher mountains of the northern states and Canada, and migrating to lower or warmer areas to spend the winter, but whether they winter in caves or go south to a warm climate is not known. 
The rather small size, eleven-inch spread of wings, and black fur and membranes, often give ample recognition characters while the bats are on the wing, but the silvery frosting on the black back is the most striking character of the species.

\section{RED BAT}

Nycteris borealis

Two skulls of the little red bat were found on the floor of the deepest room in the cave. They were very old and fragile, and had been there many years. The teeth were all gone, but the cranium was complete in each. So little is known of the winter resorts of these bats that every cave record is important. In summer they are tree bats, spending their days hanging among tufts of green leaves in the branches, and this record is probably of a hibernating colony.

Red bats are of medium size, with very short ears and golden brown fur.

\section{HOARY BAT \\ Nycteris cinerea}

A very large gray bat found hanging in a bush in the gulch below the cave by Jim White in the fall of 1923 must have been of this species. He said it was squeaking and screeching in a very savage tone when he found it, but as he did not disturb it, I suspect there were two of them. This is of course a migration record but I could get no definite date for it. These are northern bats that migrate at least to the southernmost parts of the United States, but there seem to be no records of 
their entering caves. They may not regularly hibernate. In summer they are tree bats, spending the daylight hours hanging head down in the dense foliage of treetops.

The hoary bat is the largest species known here, with a spread of wings of about sixteen inches. The ears are very short and wide, and the long soft gray fur is grizzled with buffy or whitish tips.

\section{HOUSE BAT}

Myotis incautus (Fig. 42)

These little pale brown bats are fairly common here. At the Santa Fe water tower, four miles southwest of Carlsbad, on the evening of July 29, 1901, I shot four of them as they came to the water pool to drink at dusk, flying in a straight line from the low limestone ridges to the northwest, and moving so evenly as to be easily shot on the wing. Usually in their zigzag flight after insects bats are very difficult to shoot, and a dozen or more shots would be necessary to procure four specimens. I remarked at the time that the bats must have come from a roosting cave, as they came in the same line and were too thirsty to stop to catch insects. Twenty-three years later, on May 2, 1924, Bob Dow and Carl Livingston went with me to a cave in the top of one of these limestone ridges about a half-mile northwest of the same water tank, where hanging to the low roof of the cave were about one thousand of these bats. The weather was warm, the cave warm and dry, and the bats were fully active, and easily alarmed by our flashlights. They hung in a mass several yards in 
extent, closely huddled together, but not pendent from one another. As we approached closely with the lights, they began to fly, the outer row leaving first, and others as fast as exposed. I grabbed a handful of the bats from the bunch and then retired leaving most of them where they were. A few days later we brought a motion-picture camera and tried to photograph them as they hung in the mass and as they left it and flew away, but the lights were inadequate and no pictures were obtained. They were five or ten minutes in leaving the bunch, but settled all over the roof of the next room, and then, when disturbed, flew through a low passage into a third room, to the far ends of low tunnels, and into cracks and nooks and corners, where they attempted to hide from the lights as we approached. In a narrow tunnel, where my body almost filled the passage, they would try to pass me, but turned back so quickly that I could rarely catch one in my hand. A few left the cave through the narrow shaft at the top, but most of the colony hid away in the numerous galleries and dark corners.

Only one other bat of this species was found, this on April 13, hanging from the roof of McKittrick Cave, twenty miles west of Carlsbad. It was active and full of fight, while several Corynorhinus hanging near it were cold and torpid. A very old skull was found in the farthest, deepest room of the Carlsbad Cave, showing that they had once occupied this room.

All but one of those taken in the cave were females, as were also all of those shot at the water tank in 1901; but four others caught at the Ball's Ranch near the 
Pecos River on September 17, 1901, were all males. The caves are evidently their breeding grounds, although Doctor Allen first recorded them from specimens taken in a house in Texas, and so gave them the name of house bat.

The house bat is a small pale brown species, with narrow ears, and a spread of wings of about eleven inches. It weighs six or seven grams.

\section{FRINGED BAT}

\section{Myotis thysanodes}

This rather large brown bat, with large, thin ears, weighs about eight grams. One was found dead in the rain barrel close to the ladder entrance to the big cave, and as the species is a regular inhabitant of caves, it had probably come out of the open shaft and in trying to get a drink from the barrel had fallen into the water and was drowned.

The fringed bat has a spread of wings of about $11 \frac{1}{2}$ inches. It is best marked by the hairy edge of the tail membrane.

\section{CAVE BAT}

\section{Myotis velifer}

An imperfect skull of this species was found in the deep, far room of the cave, but like the skulls of other species from there was very old and fragile and incomplete. No signs of recent occupation of this room by bats were found, and it seems probable that some old entrance from the surface has been closed within recent years. In fact, a large sink hole over the top of this 

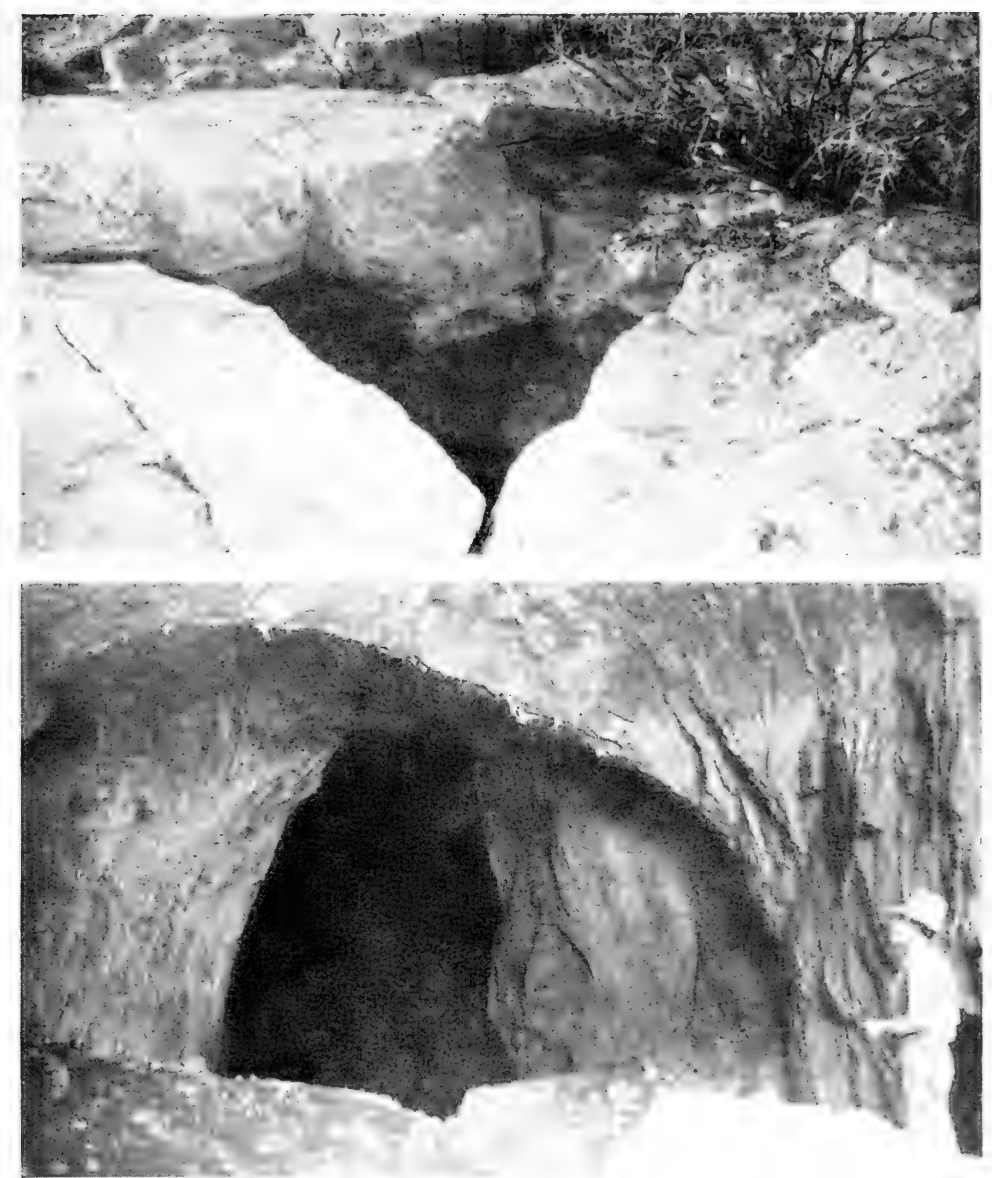

Upper: Fig. 46. Entrance of Bat Cave in Dow's Pasture, Four Miles West of CARlsBad

About one thousand house bats (Myotis incautus) were occupying this cave.

Lower: Fig. 47. Sladghter Chie in Slatghter Cayyox

Three dead ring-tails were lying in the entrance, victims of poison distributed by goat herders. Also much bat guano had been taken from this care. 

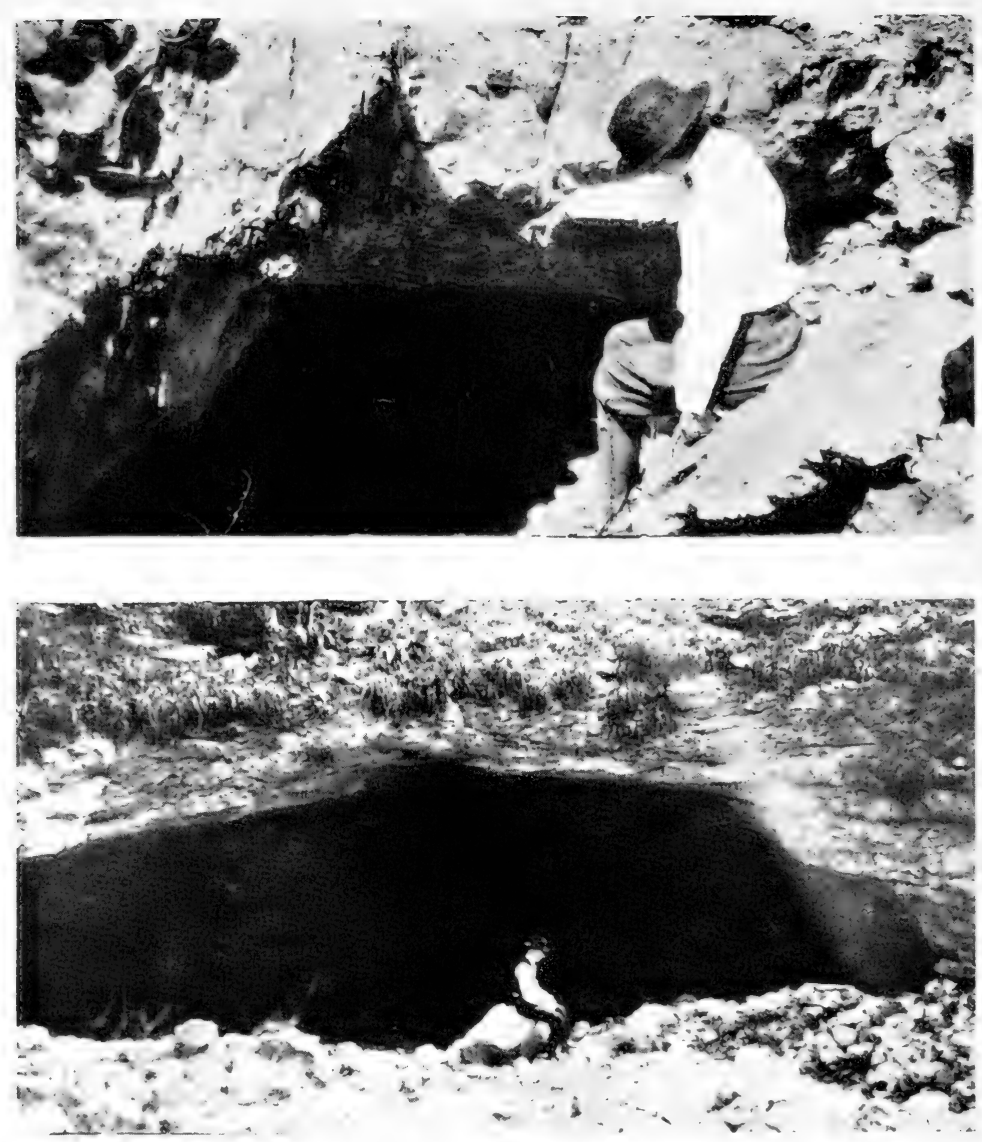

Upper: Fig. 48. Entrance of McKittrick Cave, about Fifteen Miles West of Carlsbad

The long-eared jack-rabbit bats were found hibernating in this cave

Lower: Fig. 49. Entrance of Sevoya Cave, Nineteex Miles North of Sax Axtonio, Texas

Great numbers of guano bats spend the year in this cave and produce an annual crop of about 60 tons of guano. 
room shows where the earth and rock have caved in and evidently filled an original opening.

The cave bat is a medium-large, dull brown bat, with short, pointed ears.

\section{CALIFORNIA BAT}

\section{Myotis californicus pallidus}

One old skull of this little bat from the deepest room in the cave was found among other bat bones of about the same age.

The little pale California bat is one of the very small species. It has a spread of wings of about nine inches, and is of a pale brown color, with dark brown membranes.

\section{CANYON BAT}

Pipistrellus hesperus hesperus (Fig. 41)

These pale buffy bats, with strikingly black wings and ears, are the midgets of our northern bats, adults weighing four to five grams, and their wings spreading only about eight or nine inches. They are the most abundant bats in the canyons, where they swarm around the springs and waterholes early in the evening, but are so quick and crooked in flight as to be very difficult to shoot. A considerable number were collected, but at a large waste of ammunition. They seemed to appear suddenly from cracks in the canyon walls, but no special caves or gathering places could be found. Some small bats, probably these, were seen flying about in the mouth of the big cave, but no trace of them could be found inside. 


\section{CHAPTER 6}

\section{BIRDS OF THE REGION ${ }^{1}$}

In the immediate vicinity of the cave entrance, there is no surface water except for a brief time after a rain in rock pools. Even our drinking water was packed on a burro over the limestone ridge from a spring in another canyon a mile away. But to reach the cave from the railroad one must come in from the Pecos River some twenty miles to the east, or across the Black River two or three miles to the south, where permanent water attracts many forms of swimming and wading birds, and the mild climate keeps some of them there through much of the winter season. During spring and fall migrations the Pecos River teems with wild geese, swans, ducks, coots, grebes, cranes, herons, and a great variety and abundance of wading birds,-curlews, avocets, black-necked stilts, willets, yellowlegs, snipe, sandpipers, plovers, and phalaropes. An occasional cormorant or anhinga comes up the river from farther south.

Of the migratory land birds great flocks of black-

1 This brief list of the birds of the Carlsbad Cave region, far from complete, merely mentions some of the more interesting of those observed during a stay at the cave from March 11 to May 10, 1924, and on several previous visits by Mrs. Bailey and myself to Carlsbad and the Guadalupe Mountains. Notes on the wintering of water birds have been contributed by Carl Livingston, of Carlsbad, who has spent many years in the valley, but no attempt has been made to use all the information at hand. The notes are for the purpose of showing the unusually interesting nature of the bird fauna of the National Monument under which the cave region is being preserved for study. 


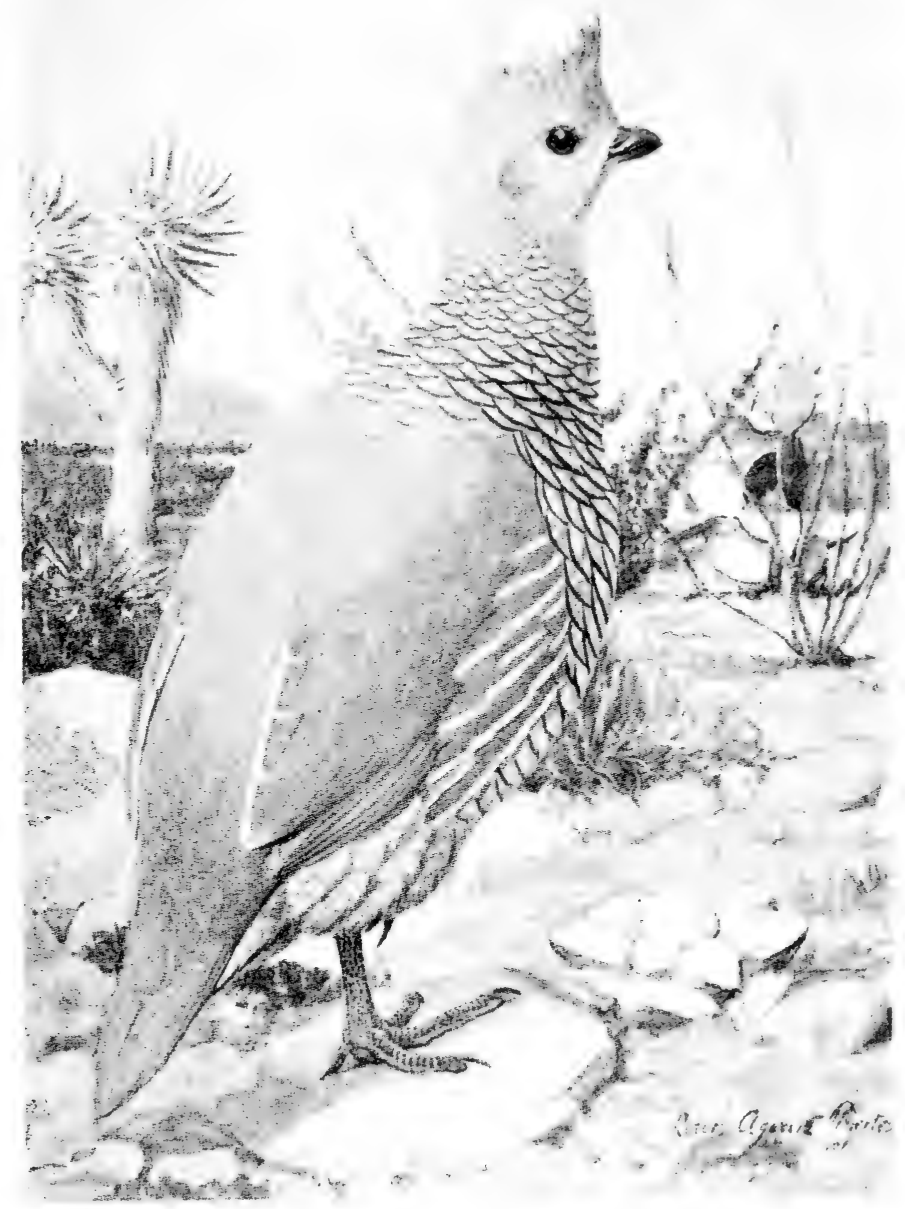

Fig. 50. Scaled Quail, Blde Quall, or Cotton-top

A common bird about the entrance of the cave when we were there in the spring of 1924. Drawing by L. A. Fuertes. From Handbook of Birds of Western United States, Permission Houghton Mifflin Co. 


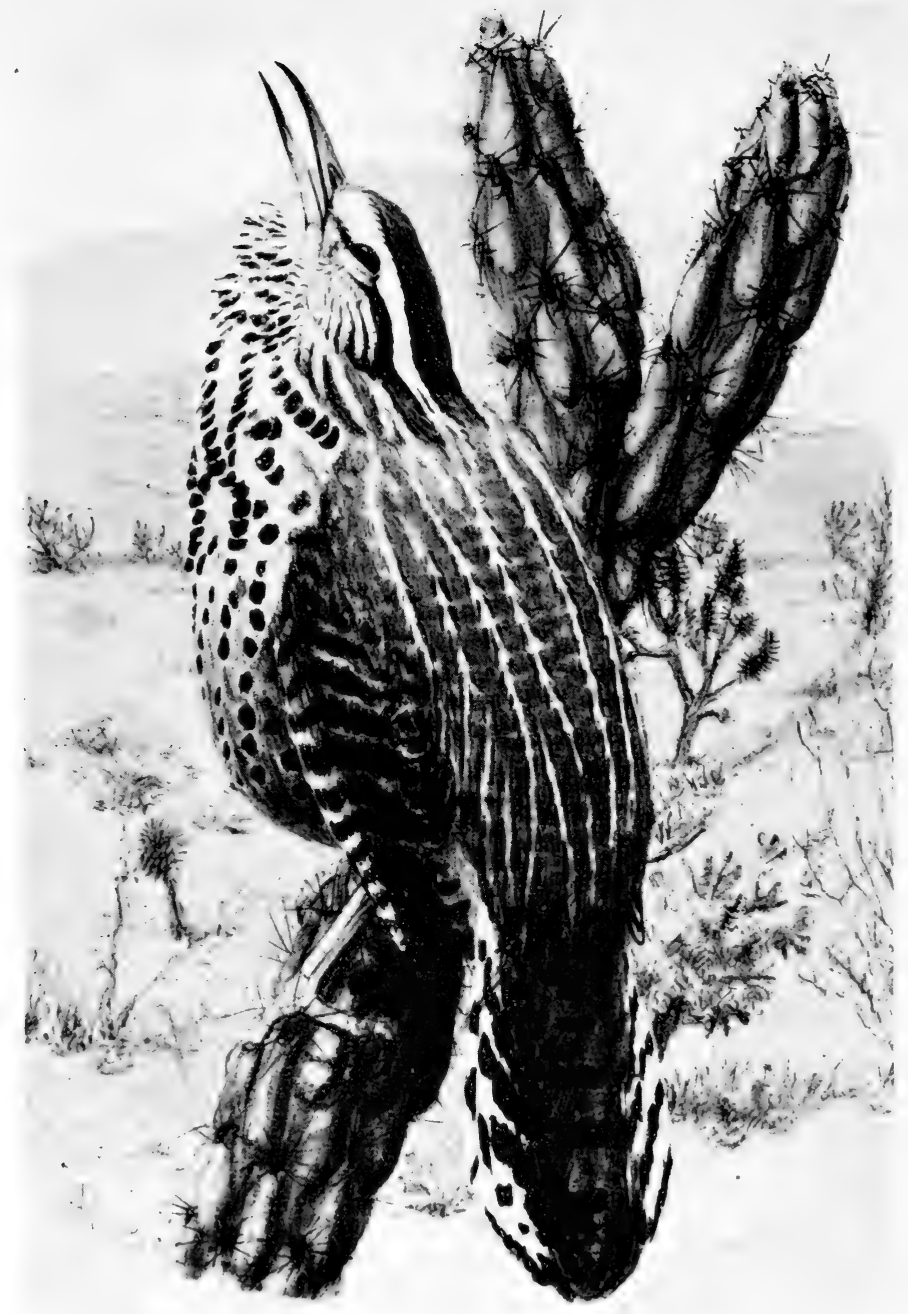

Fig. 51. Cactus Wrex. The Sun Singer

Many of these large wrens nest in the cactus bushes around the cave. Drawing by L. A. Fuertes. Courtesy of Biological Survey, U. S. Department of Agriculture. 
birds,-yellow-headed, rusty, Brewer's, red-wings, and cowbirds,-swarm into the valley in fall and spring, as do also the white-winged buntings, longspurs, juncos, many other sparrows, horned larks, meadowlarks, and some warblers and vireos.

The birds of greatest interest, however, are the native breeding or resident species, many of which are of peculiar desert forms able to live at considerable distances from water, or are entirely without a visible source of water supply even during the nesting season. Others remain always within easy reach of water and serve as useful guides to the location of springs or waterholes. A few are valuable game birds, while some are important scavengers. Some of the predatory birds are exceedingly useful, and others are more or less harmful from man's point of view. Some of the seed-eating birds occasionally injure crops to a slight extent, but they also protect the crops by destroying myriads of weed seeds, while the insectivorous birds are as indispensable a part of the desert economy as they are in more fertile sections of the country.

The scaled quail, blue quail or cotton-top (Fig. 50), while generally distributed over the valleys, in canyons, and on the open hill country, is found usually within easy reach of some drinking place. They are almost as fleet on foot as the rabbits with which they range, and do not mind running a mile or two for a drink of water. Large flocks visited the cave buildings daily for the scattered grain we kept out for them and the sparrows, and also visited the spring in the next canyon a mile away and a rock tank a couple of miles below 
the cave in our own canyon. They are very responsive birds when not so frequently alarmed as to be afraid of man. Often twenty or thirty were seen running about among the buildings, and sometimes were at our very doors when we got up in the morning. Some would perch on the rock piles, or even the house tops, and sound their cheerful call notes to others scurrying over the sidehills. With adequate protection and the encouragement afforded by a few sacks of grain, these birds could be kept as one of the delightful features of the cave region.

The Mearns quail, or as locally known, the "fool quail," has one of its remaining strongholds in the Guadalupe Mountains, and occasionally a few of the birds come down on the juniper ridges to the vicinity of the cave entrance. These plump little partridges, with short wings and strong feet, and striking color pattern, have a very limited range near the Mexican border, and from their gentle and confiding natures seem in actual danger of extermination. This is perhaps the best remaining place to study their habits. It is now well known that their unusually large and strong feet and claws are used in tearing up small bulbs, onions, and rootlets from the ground for food in summer, but how they live in winter, how they get along without water, and to what extent their naturally gentle natures could be cultivated are factors wholly unknown. Their flesh is darker and more delicious than that of most of our other quail, and their domestication, if accomplished, might prove of much practical value. 
The Merriam turkey, once abundant throughout the Guadalupe Mountains and down nearly or quite to the cave level, has been killed in recent years until hunters now find it necessary to go north of Queen before any of these magnificent birds are encountered. Considerable numbers are still found, however, in the Sacramento and White mountains, and better protection might easily restore them to their former range on the rough ridges west of the Carlsbad Cave, where an abundance of food and dense cover afford ideal conditions for them.

Band-tailed pigeons are said still to breed in the Guadalupe Mountains, where twenty-four years ago Mrs. Bailey and I found them nesting in the extreme head of McKittrick Canyon. Their large size, owllike hooting, and the loud flapping of their broad wings, render them conspicuous in any forest, and here at the extreme southeastern corner of their range their presence has a special interest. At one time rigidly protected for fear of their suffering the fate of the passenger pigeon, they have in recent years shown a marked increase in the far west and if given a chance will undoubtedly hold their own. Nevertheless, the places where they can be studied are all too few.

The common mourning doves are generally distributed over the Pecos Valley in summer, and a few appeared at the Carlsbad Cave during the latter part of March. They did not become numerous during my stay up to early May, but were evidently in breeding numbers. The pelvis bones of one, heavily encrusted with lime, were found in the cave near the Devil's Den, back half 
a mile from the entrance. They may have been carried by an owl or ring-tail, or may have been washed in from the entrance of the cave.

Turkey buzzards at times seem more abundant than an arid region ought to require for scavengers, but the cliffs and canyon walls afford such irresistible nesting sites that they gather here in unusual numbers to breed. None was seen before March 24, but during the first half of April they became fairly numerous, often in gatherings of one hundred or more. They would fly over the canyons, or on cold windy evenings would settle on the rocks or ground or in low trees in some spot sheltered from the wind and where they would catch the first warm rays of the morning sun. They would not leave the roosting spot until well warmed, and at eight or nine o'clock might be seen sitting with widespread wings catching all the rays of warmth they could reach. Sometimes two or three hundred were seen together on the roosting grounds. White downy young were found in the nest before the first of May, while others were not yet breeding. A dry winter and scanty forage for stock insured them a food supply from dead cattle and burros in the canyons, and once I found about a dozen feasting on a dead colt, killed and partly eaten by a mountain lion. Unlovely birds as they are, their usefulness as scavengers is generally acknowledged, and their graceful soaring has long been the admiration and envy of would-be human aviators.

Of the diurnal birds of prey there are golden eagles and many hawks,-western red-tails, Swainson, ferruginous rough-legged, a few marsh hawks, occasionally 

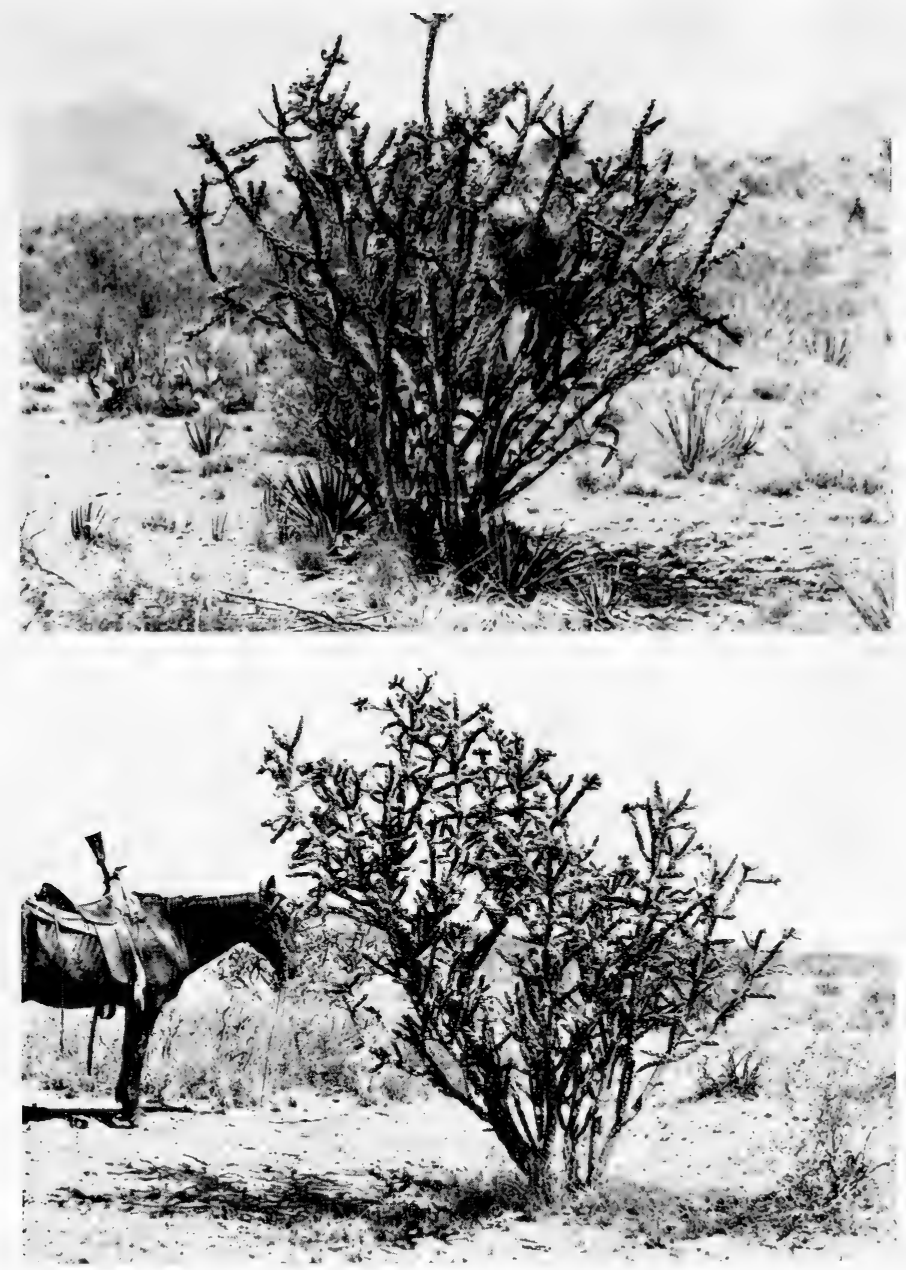

Upper: Fig. 52. Nest of the Cactus Wren in Cactus Bush

The thick-walled nest of securely woven plant fibers lined with feathers and opening through a neck at one side furnishes a warm sleeping room for winter as well as a safe nest for the young in summer.

Lower: Fig. 53. The Cane Cactus (Opuntia arborescens) in Fruit

With nest of curved-billed thrasher safely hidden in the center of its spiny branches. 


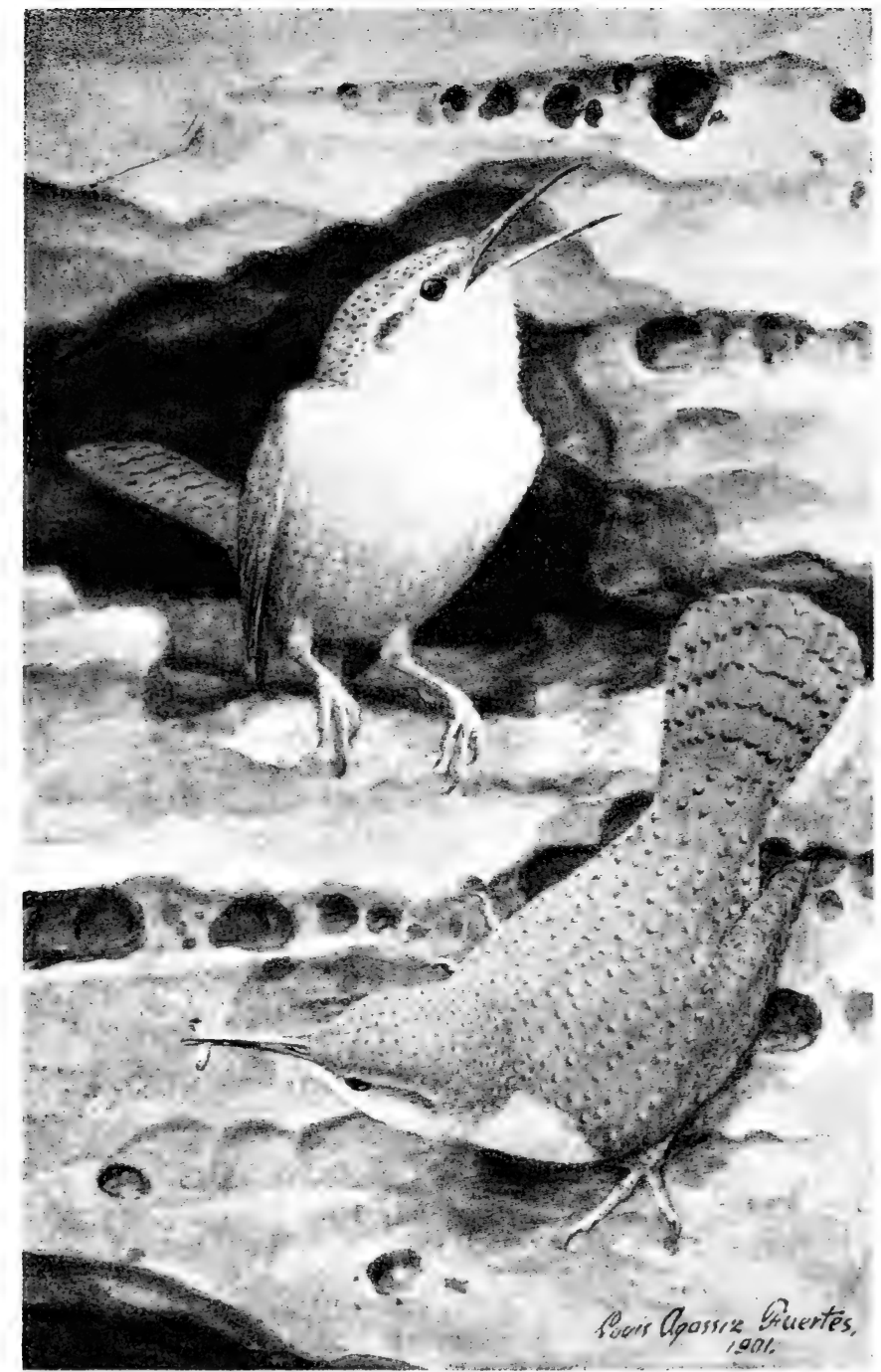

Fig. 54. Canyon Wren. A True Cave Dweller

Nests of these wonderful singers were found in or near the entrances of many of the caves of the region. Drawing by L. A. Fuertes. From Handbook of Birds of Western Inited States. Permission of Houghton Mifflin Co. 
a zone-tailed hawk, many sparrow hawks, and a few prairie falcons. There would be more golden eagles, as shown by many old and unoccupied nests, but for the goat industry and the fondness of these powerful birds for young kids. It is perhaps well for the young of some of the game animals, especially antelopes, deer, and mountain sheep, that the eagles are not more numerous. Nevertheless, it is almost a daily occurrence to see one or more of these great birds soaring high above, scouring the cliffs for game, or making a long dive into the valley for a jack rabbit. The western red-tails are perhaps the commonest breeding hawks along the cliffs and canyon walls, where bulky stick nests are often seen. Sparrow hawks also breed along the cliffs, and occasionally a prairie falcon. A ferruginous rough-legged hawk came into the entrance of the cave on windy days in April and sat in an old nest under the great archway, perhaps its own nest of previous years, but the many visitors kept it away except when it was driven to shelter by raging storms. Many carcasses of these big, beautiful, and useful hawks were strewn along the roadsides in the valley, having been shot from passing automobiles as the birds sat on fence posts or telephone poles watching for ground squirrels, their favorite food. Few hawks are of greater value to farmers in the plains and prairie country where ground squirrels are a serious pest, and few do less harm to birds, game, or poultry. OneSwainson hawk, another harmless species and very useful as a grasshopper and rodent destroyer, was seen dead by the roadside, the only one noted where there should 
have been many. Will people ever get over the kill-for-fun habit, or must they be wholly disarmed?

The owls of the country are few in number, but all useful in habits. A few great horned owls, barn owls, screech owls, and the funny little burrowing owls are found in the valley and cave country, and the spotted owls up in the Guadalupe Mountains. Of these the little round headed burrowing owl or prairie-dog owl is the most frequently seen, because he sits on a mound by a prairie-dog or badger hole in the daytime, and bows and bobs to passers-by, or flies away to another burrow, where perhaps he has a mate and nest of eggs or young deep underground in a hole deserted by its original owner. If so, tails and feet of kangaroo rats, bones of mice, and legs and shells of a great variety of insects, will be seen scattered about on the ground from the disgorged and disintegrated pellets. Rarely a bird feather is found, for these little owls live almost exclusively on insects and small rodents. They often live at long distances from water, and probably can get along without other moisture than what is obtained from their food.

Great horned owls live in the Carlsbad Cave, under the huge arch that spans the doorway, where for untold generations their nests have occupied the high niches in the rocky walls, and owlets have been safe from storms and most of their enemies. Even the savage red men who once occupied the cave with them were loath to point an arrow at the sacred birds of the night, but in recent years civilized visitors, to whom nothing is sacred, have shot some and driven others away to nest 
in less frequented caves and cliffs. However, the owls pay nightly visits to the cave, as shown by plumy feathers clinging to bushes at the entrance, and by the deep toned hoo, hoo, hoo, ooo, breaking from the quiet darkness of the great doorway. In the first big room of the cave, owl pellets were found on the rocky shelves; and far back at the brink of the Devil's Den, beyond the last ray of outside light, a complete skeleton of an owl was picked up on the cave floor, perhaps a tragedy of utter darkness, for, wonderful as the eyes of an owl are, no eye can be conceived that could render vision where no light exists.

Outside of the cave and a little way down the canyon a pair of these owls had a nest in a shady niche, high up on the face of the cliff. Here on April 10, a mother owl was covering her two white downy young in plain view from the trail, but so protected by her mottled dress that when her big yellow eyes were shut she might well have passed for a part of the cliff. I took her picture, first from across the canyon. Then in order to get a nearer view I climbed the wall to the level of the nest, crawled out on a rock within six feet of it, and snapped her several times with my little pocket camera before she would leave her young. As usual in dark corners, the snapshots were under-exposed and gave only a faint trace of the picture.

In several neighboring caves the owls were nesting in high niches, well back in the gloomy twilight, safe from prowling enemies and safe from man as long as they would sit tight and not reveal their presence. To a close observer, however, their presence was easily 
surmised by the pellets and small bones which strew the ground wherever they nest or roost.

Down by the river a pair of horned owls had a nest in the crack of a bold cliff above the river bank. On March 25 there were three snow-white downy young, only a few days old, with big, wobbly heads, blinking eyes, strong legs, and hooked claws, already useful in clinging to the nest and rocks. The mother bird was covering them with her warm breast feathers and refused to leave until I came within a few feet of her, and then only after savagely snapping her bill at me. She hissed, and puffed her feathers, in dire threats that would have been heeded had I not been well balanced on the shelf, from which I hoped to get a photograph of the owlets. Having once long ago felt the claws of a mother owl in my back while approaching her young, I had no desire to repeat the experience. So I took my snapshots quickly and crawled back along the narrow shelf, but not before the anxious mother had returned, bringing her mate with her to help drive off the enemy. Both came close, hooting and snapping their bills at me in threatening tones as I hurried down over the rocks to allay their fears and let them go back to the young, which were already shivering in the cold wind. The mother was soon back on the nest, sheltering the young, while the old male hooted occasionally from a neighboring rock as I remained below to study the scraps from their table.

On one side of the owl's nest the fresh body of a half-eaten cottontail was seen, and the crops of the young owls bulged with the tender meat, carefully 


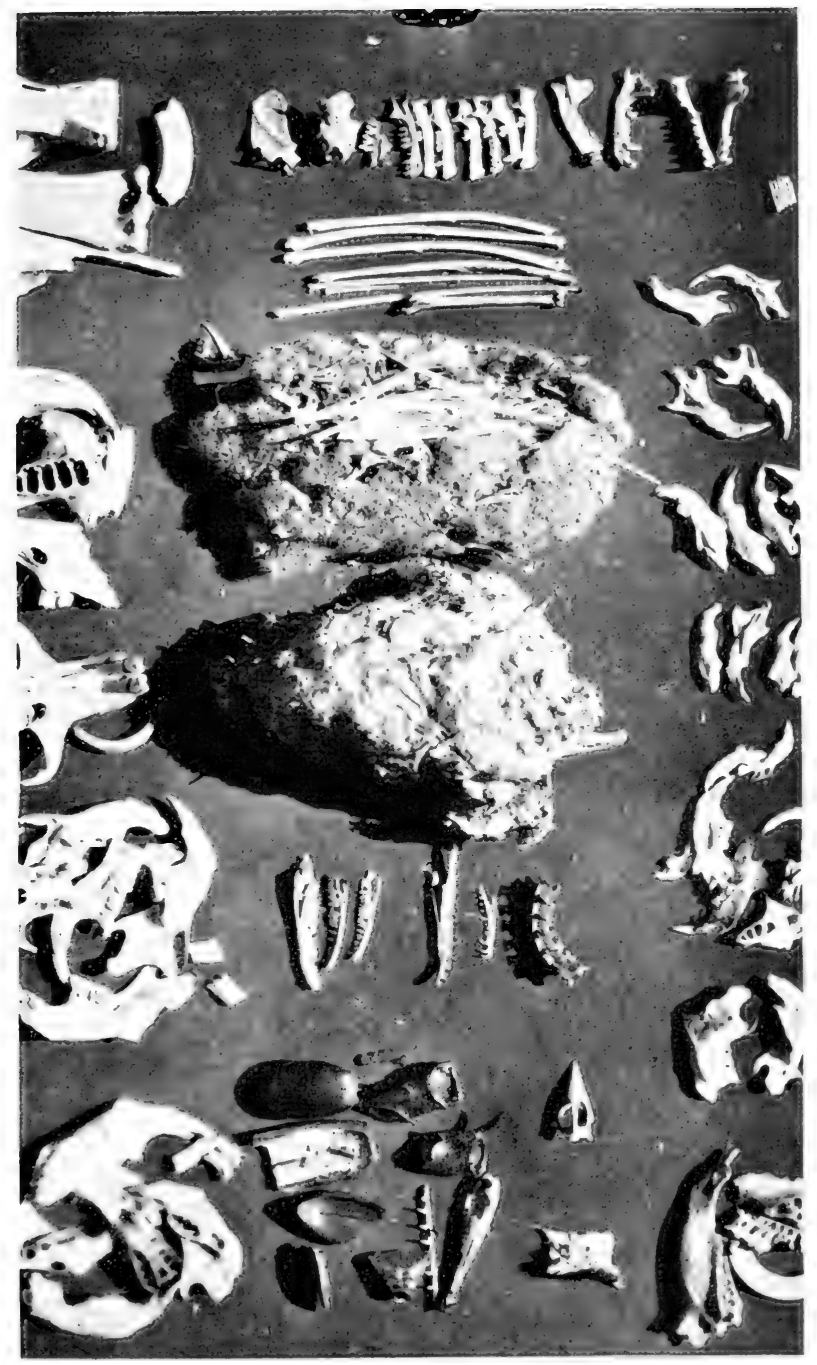

Fig. 55. Two Regurgitated Pellets of the Great Horned Owl

Some of the bones from disintegrated pellets found on the ground under the owl's nest in the main entrance of the cave. Most of the small mammals of the vicinity, one small bird, snakes, lizards, horntoads, and many insects were represented. 

picked off and fed to them by the parents. However, most of the owl story was read at the base of the cliff in pellets of fur and bones regurgitated from the stomachs of the old owls, and by thousands of bones of small animals scattered over the ground from old, disintegrated pellets. As is well known, such small animals as mice and rats are swallowed whole by owls, while larger game up to the size of rabbits is torn apart and bolted in coarse pieces,-fur, feathers, bones, and all. The whole is retained in the stomach until the food part is digested, when the remaining felted mass of fur, feathers, and bones is gulped up and thrown from the owls' mouths. In course of time these pellets (Fig. 55) drop apart and leave bits of bones scattered over the surface of the ground. Most of the bones were easily recognized as having belonged to the small mammals of the region, but some, requiring more careful study and comparison, were brought back, and were identified by Remington Kellogg of the United States Biological Survey.

Examination proved there was much similarity in the pellets and bones from different caves and cliffs, the principal variation depending upon local abundance of the various kinds of prey eaten. The main local differences consisted of considerable numbers of bones of the guano bats in the Carlsbad Cave, the bones of white-throated swifts in the Bighorn Cave, and the bones of ducks and fish near the Pecos River. The bones not only indicated the regular food of the owls, but also represented practically the whole rodent and small animal population of the region. By far the greater 
part of these bones were those of the common rodents, such as jack rabbits, cottontails, wood rats, kangaroo rats, cotton rats, pocket gophers, ground squirrels, white-footed mice, grasshopper mice, and pocket mice. Two of the little spotted skunks had been eaten; the Guadalupe meadow mouse was represented by one tooth; a few bats of several species were represented by jaws; while in the big cave considerable numbers of the guano bats had been swallowed whole, one of the pellets shown in the illustration being composed almost entirely of bat bones and fur. Near the river there were feathers and bones of ducks, probably cripples from the hunting season, and in caves in other localities were found a few fragments of bird bones, one of a coot, one of a black-headed grosbeak, one of a sparrow, and one of a towhee. These were so few in comparison with the total number as to be of little economic importance, and formed by no means a regular part of the owl's diet. There were also a few bones of several species of snakes, of three species of lizards, of a horntoad, and some catfish bones, together with large numbers of extra legs, and other hard parts of many different kinds of beetles, grasshoppers, moths, and large vinegaroons. Although even the harder parts of many species quickly disappear and with them the evidence, insects apparently formed a far larger and more constant part of the owl's food than did birds or reptiles.

Aside from the unusual cases of local destruction of bats and white-throated swifts, where found living in dense colonies, the food of these owls is mainly of direct benefit to man. The check on over-abundance of 
rabbits, wood rats, pocket gophers, kangaroo rats, and numerous species of mice, is of vital importance in an arid region devoted to agriculture and grazing, and if removed would necessitate great expense in artificial control of rodent pests. If the farmers and ranchmen realized how useful the hawks and owls are to them, fewer of the dead birds would be seen lying along the roadsides, victims of thoughtless "gun toters."

The yellow-billed cuckoos are found in the valley, where their function of keeping the trees free frum caterpillars is generally appreciated. The road-runner occurs over the valleys and hills, where the open country gives free scope to its propensity for speeding and provides abundance of game in the form of lizards, snakes, grasshoppers, and other large insects. These birds were often seen about the entrance of the great cavern, and their characteristic stick nests were recognized in the blue-thorn and buckeye busbes down in the deep pit of the west entrance, as well as in some of the tall yuccas out on the ridges and along the bottom of the canyons. Occasionally one of these droll, longtailed birds was seen close to the cave buildings, and on several occasions one came and peered into my cabin door, snapping its bill and making its characteristic low koo note. Late in April their louder notes were often heard from the sides of the gulches, where the birds were evidently searching for new nesting sites.

The woodpeckers of the cave region are naturally few in number of species, although the little spotted cactus woodpeckers are fairly common and often seen along the roads, tapping on dry stalks of sotol, lechu- 
guilla, or yucca, or pecking holes in the larger trunks of the cane cactus, or in some old trunk of a live oak, or even in a fence post. They are true desert dwellers, and are apparently as important to the protection of desert vegetation as are other species to the welfare of our forests.

Red-shafted flickers are common about the cave in migration at least, and during late March and early April two were living in the mouth of the great cave, apparently spending the nights in small holes in the limestone wall, high up under the arched doorway. On several occasions they were seen trying to drive away the pair of sparrow hawks that also had staked out claims in the doorway, and once they were seen attacking a rough-legged hawk that had taken refuge there. Later, however, they disappeared, probably moving northward or higher up in the mountains to their regular breeding grounds.

A little higher in the hills the beautiful ant-eating woodpeckers store acorns in the bark of oaks and yellow pines, and occasionally a few of the big black-backed and red-bellied Lewis's woodpeckers are seen.

Both the western and Texas nighthawks occur here at the cave, or in the valley nearby. On warm evenings after the middle of March the plaintive poor-will was often heard softly whistling its name near the camp buildings at the mouth of the cave and over in the canyon near the spring. More fully nocturnal than the nighthawks, these small goatsuckers are rarely seen in the daytime unless flushed from their roosting place on the ground, when they fly a short distance on soft, 
rounded wings to another resting spot. But their unmistakable note is one of the delightful, soft, plaintive sounds of the night, adding a rare charm to camp life on these wide stretches of open country.

White-throated swifts are often seen hustling over the cave entrance, their white, V-shaped throat markings conspicuous against the black body, rendering them unmistakable, as do also their lightning-like speed and strident notes. In the Bighorn Cave in Slaughter Canyon, some fifteen miles directly west from the Carlsbad Cave, a colony of these swifts has long nested in a great crack in the roof, some seventy-five feet above the floor. This is an old breeding ground, as shown by about a ton of guano and a bushel of swift feathers on the ground underneath, and the fact that some years ago three carloads of swift guano were taken out, packed down the trail on burros, and shipped to California as fertilizer. On April 30, 1924, about a dozen of the swifts were seen, circling in and out of the cave, entering and leaving the breeding crevice, but these were doubtless only the early arrivals from farther south. Owls and ring-tails had evidently preyed upon them extensively, judging by the bones in the owl pellets and the great numbers of wing feathers, with quills clearly cut by the teeth of some carnivore. Both of these enemies were common in the cave.

Hummingbirds began to appear in the canyons on March 29, and were common about the flowers of the Mexican madrone tree, the goat-bean bush and the Mexican buckeye, and later about other flowers as they appeared. The black-chinned was the first to 
arrive and the last seen. The broad-tailed came soon after the black-chinned and was also common tbrough the early part of April, leaving later for its higher breeding range in the Guadalupe and Sacramento mountains. The black-chinned remains to breed at the caves and actually nests in the great doorway of the west entrance to the Carlsbad Cave, and under the arched entrance of the Bighorn Cave, fifteen miles farther west. I was hoping to find the blue-throated and other hummers when the ocotillos spread their scarlet flags over the hot slopes, but was compelled to leave on May 10 before they were fairly out.

Of flycatchers, the gray-backed, yellow-bellied Cassin kingbirds are most conspicuous in the cottonwoods of towns and ranches in the valley, where they breed in friendly proximity to man, while the scarcely distinguishable Arkansas kingbirds seem to be more commonly found up in the hill country. A few ashthroated flycatchers, with brown crests, were seen around the cave in April, and they undoubtedly breed in the vicinity. A few small flycatchers of the genus Empidonax were seen about the cave, but as no specimens were collected the species can not be given. The wonderful scissor-iailed flycatchers are said to breed at the Livingston Ranch, thirty-five miles east of Carlsbad.

The brown-bellied Say's phoebe, called locally the cavebird, because a pair actually nests down in the natural shaft of the cave, is one of the common and very friendly birds of the region. Single birds or pairs were seen over valley and canyon country from the time of my arrival, 
March 10, 1924. It is not improbable that this species may spend much of the winter here or at slightly lower levels, using the caves for protection from cold and storms, as well as from the extreme heat of summer. Early in April the pair of birds occupying the cave shaft were found to have a nest about thirty feet below the surface, but in an inaccessible opening in the rocks where the eggs and young could not be seen. The birds were often seen at the nest, and later were regularly carrying food to the noisy young. Jim White told me that they have nested here every year since he has known the cave, about twenty-three years. Others were found nesting in three other caves nearby. These records together with their well known babit of nesting down in the shafts of old wells indicate their fondness for subterranean protection. Apparently they do not go back to the dark parts of the caves, but stay in the cool, shadowy shafts, where there is a dim light. During March and April both of the nesting birds above mentioned regularly entered the shaft at night to roost in the warm cave air safe from outside enemies. As great numbers of moths and other insects also take refuge in these warm shafts, the birds may find an important part of their food here, even in cold weather. In fact, caves and caverns seem to account for the presence of these flycatchers in surprisingly cold winter climates.

Horned larks migrate through the Pecos Valley, and one or two of the forms stay to breed out on the open parts of the plains country and on top of the Guadalupe Mountains. 
A few of the uncrested Woodhouse jays were seen in the brushy pit at the west entrance to the great cave, and others along the canyons both above and below. They were especially common in Slaughter Canyon a little to the west, as they are all through the foothill country of the Guadalupe and Sacramento mountains.

White-necked ravens (Fig. 57), in size half-way between the common crow and common raven, are abundant over the valley country, where they nest in many of the tallest tree yuccas, and after the breeding season gather in large flocks like crows. During March and April they were mostly in pairs or small parties of five or six scattered out over the country and evidently looking for nesting places. One picked up in the road on March 25, had been shot "just for fun" by some passerby. It made a good specimen, and its stomach was found well filled with ants and beetles. At times these birds may do some mischief to crops, but generally they are useful as insect destroyers or scavengers.

Western meadowlarks are common over the valley for much of the year, and their rich song is one of the joys of the roadside chorus.

The commonest oriole about the cave is the large, lemon yellow, black-headed Scott oriole, with its loud, rich song, which was frequently heard along the canyons during April, as the birds were inspecting their last year's nests in the tall yuccas, or catching insects from the yucca and cactus flowers. Later, as the century plants and lechuguillas blossomed, they would find both food and drink, since they gather the rich 


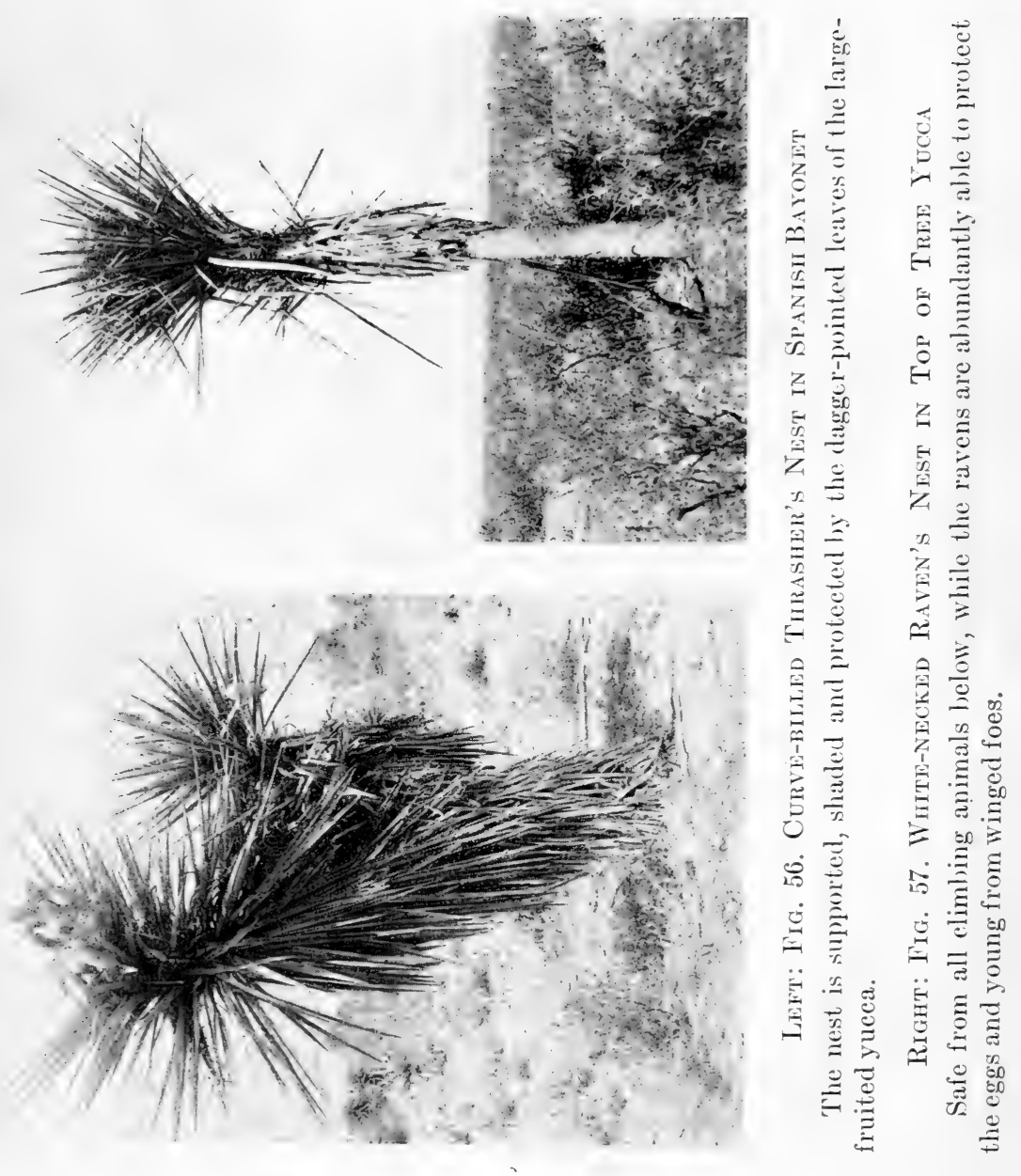



stores of nectar as weil as the insects from these blossoms.

One of the most beautiful male Sennett orioles that I ever saw was examining the materials of a cactus wren's nest in a cholla bush at my cabin door on March 24 , and several other individuals were seen later about the cave. Their flaming orange bodies and black heads make a startling color pattern of unusual beauty.

Bullock orioles are common in Carlsbad, and wherever the cottonwood trees furnish swaying branches for their basket nests and juicy caterpillars for their food. Their rich songs are heard all day in the tree tops, and an occasional flash of orange and black, with white wing-spots, identifies the singers.

An occasional brilliant painted bunting, western blue grosbeak, or cardinal is found nesting in the Pecos Valley or in the canyons along the sides of the valley, while the little brown Cassin sparrow would be easily overlooked but for its enthusiastic flight song, uttered in a wild abandon of joy as it flutters over the mesquite tops.

The Mexican house finch is one of the best guides to springs and water holes in this arid region, as it is rarely found far from a supply of drinking water. In the canyons the nests of this species found among the dry leaves of tall yuccas, or inside of old oriole nests, are generally an indication of springs or rainwater holes in the rocks. In town and about ranches these bright little crimson-headed finches are among the most familiar and cheerful members of the bird population, always warbling and twittering in a happy strain as 
they build their nests and raise their young among the vines and shrubbery of the dooryard or in the nearest trees about the houses. To some extent they seem to crowd out or successfully compete with the greatly disliked English sparrow and to hold their own in close proximity to man.

Goldfinches, western vesper sparrows, western lark sparrows, western chipping sparrows, white-crowned sparrows, juncos, black-throated sparrows, and rock sparrows were all more or less abundant during April about the cave, some on their way to higher or more northern breeding grounds, and some waiting only for warmer weather to begin nest building in the cave region.

The green-tailed and arctic towhees are common in the canyons and thickets and occasionally seen in the brushy doorway of the great cave, while the brown canyon towhees are common and friendly birds around the cave buildings. These last-mentioned birds were generally to be seen picking up crumbs about the dooryards and woodpile, and were quick to come to grain scattered out for the quail. They also came to my porch and doorstep where I swept out the seeds and rolled oats that the kangaroo rats had scattered about my room. When my door was left open, they even ventured in to pick up such food as their bright eyes were quick to see, while watching me with cautiously friendly expression. They are very talkative among themselves, and often uttered little chirps and callnotes seemingly to attract my attention, evidently considering me a harmless and rather interesting and useful addition to the fauna of the cave region. 
A brilliant rose-colored male Cooper tanager was seen in the oak trees near the spring on April 24, gleaning among the oak blossoms while waiting for warmer weather up in the Guadalupe or Sacramento mountains, where he finds congenial breeding grounds in company with his duller relative, the hepatic tanager, and the richly varied mountain or Louisiana tanager.

There is little attraction for swallows about the cave, but along the river valleys barn, bank, and whitebellied and violet green swallows are common, at least in migration, while the cliff swallows were found building mud nests on the cliffs in Dark Canyon, a few miles north of the cave.

White-rumped shrikes are fairly common along the roadside fences, where they sit and watch for prey. A few were seen on the ridge near the cave. One observed pecking and pounding at something on the ground at the edge of a wood-rat house was driven away, when a half-grown wood rat was picked up with its skull broken by the bill of the butcher-bird.

Western mockingbirds are found all over the cave country, and on every bright spring morning when I opened my cabin door they were heard singing from the tops of tall yuccas and cactus bushes. Their old nests were found in cactus or thorn bushes, in many cases far from any permanent supply of water.

The curve-billed thrashers (Figs. 53 and 56) were first seen near the cave on March 20, and thereafter were common and one of the richest sc ngsters of the region. Many of their old stick nests, larger, coarser, and rougher than the nests of mockingbirds, were found in. 
tall yuccas, bush cactuses, and other thorny bushes. The birds feed largely on fruit and on ground insects, and seem to be comparatively independent of any visible water supply.

Cactus wrens (Figs. 51 and 52) are found over the whole valley country, and especially in the canyons and up over the cactus-covered ridges, where they live the year round, and build their numerous nests in the thorniest plants they can find. A pair occupied a last year's nest in a large bush cactus (Opuntia arborescens) within six feet of my cabin door at the cave camp. When I arrived on March 11 the weather was still cool, with high winds and freezing nights, but the birds were there and as much in evidence as at any time of year. One was using the old nest to sleep in at night, while its mate was sleeping in another nest on the side of the ridge above. My cabin faced the east, and through the wide cracks in the boards the sun shone across my face as soon as it came above the horizon in the morning; but always just before the sun came up the Heleodytessun-worshiper-would perch on the roof just over my door and pour out his soul in the most rapturous song of which he was capable. Often he would sing almost continuously for half an hour before starting out to hunt for his breakfast.

Later some inquisitive person pulled the nest open to see what was in it, and the wrens gave it up and began another nest in a cactus farther up the gulch. A dozen of their nests in good repair, and many of them in nightly use, could be found within a half-mile of the cave entrance, and endless numbers beyond. The 
locality affords an excellent opportunity for a detailed study of the habits of these remarkable birds.

Rock wrens occur all through the cave region, and a pair was evidently nesting in the wall of the big western doorway of the cave. Their habit of building up a little heap of stones at the entrance of a nest hole in the rocks is quaint and unusual, and their bobbing, bowing, and teetering antics and squeaky notes while they hop about on the big rocks or cling with strong feet to the cliffs and walls are especially noteworthy.

Canyon wrens (Fig. 54), with their ringing songs running down the scale, echoing from side to side of the canyon walls, and issuing from the deep doorways of almost every cave visited in this region, are among the most thrilling and fascinating of the cave birds. When I arrived on March 11, a pair was spending each night down in the ladder shaft, but later as more people were using the ladders they moved up to the west entrance, where they were usually found within the great doorway. Evidently they were considering a nest site in a crack of the wall above the door. In a small cave about three miles to the west a pair had a nest in a hole in the limestone roof back in the first twilight of the entrance, within easy reach of my hand. The hole was so filled with sticks and fibers that I could not see into the nest without injuring it, so I did not make further examinations. But on April 19 the old bird was on the nest at mid-day and evidently incubating. On April 29, a pair of these wrens was busily feeding young in a little hole in the roof of the big cave, high up on the east side of Slaughter Canyon, 
and the next day another pair of birds was found occupying a niche in the roof of a cave on the west side of the canyon.

Even while busily feeding young, the old birds sang with great spirit, sometimes while their mouths were bristling with wings and legs of moths brought in for the young. Wren-like, the parents were bringing food in rapid alternation and evidently supplying large families. May their tribe increase.

I suspect that some of these wrens remain all winter in and near the warm caves, getting their food from the numerous insects that also take refuge there, or that breed in the twilight of the first rooms.

A few lead-colored bush-tits, blue-gray and tiny, were found along several of the brushy canyons, and on April 10 , a beautiful, freshly built nest was found in Garden Canyon, about a mile and a half from the big cave. It was half-hidden in the dense branches of a juniper, on a level with my eyes, hanging like a little sack or long purse, eight or nine inches deep and with a little round hole at one side near the top. It was beautifully woven of soft, woolly plant fibers and spiderwebs, resembling a coarse woolen sock without much heel or toe, and must have been a warm and rather safe cradle for the eggs and young. He would be a heartless collector who would touch or injure one of these beautiful pockets sufficiently to see the eggs at the bottom, or even to learn all the secrets of its structure. The old birds, gray mites as they are, make frantic efforts to drive away intruders either from the nest or from their families of young as they are led about in the bushes. 
The little gray verdins, unique in habits as well as in markings, with yellow face and reddish brown shoulders, live all the year round in the valley and canyons of the cave region, sleeping at night during the winter in their warm, feather-lined nest in a thorn bush, and feeding either on insects or berries as the season provides,true desert dwellers with no fear of heat, cold, or thirst. Their globular, covered nests, woven of small and often thorny sticks, are placed in catsclaw, allthorn, bluethorn, or some other of the spiniest bushes of the region, where they are comparatively safe from attack or injury. The nests are entered by a side door, and in contrast to their bristling outside armor, are lined with feathers and the softest and warmest materials. They serve for winter beds and as a refuge from cold winds and storms, as well as affording protection to the delicate eggs and young in spring. The every-day and all-the-year habits of these tiny denizens of the deserts, if well known, would make a fascinating chapter on desert life.

Western ruby-crowned and golden-crowned kinglets migrate up and down the mountain slopes, and are common in the canyons in April. They breed high up in the mountains of the state.

Western gnaicatchers were noted in some of the nearby canyons, and probably breed here, as this is within their breeding range.

A Sierra hermit thrush was collected in April in the next canyon over the ridge from the cave, but the thrushes here are migrants on their way to their higher mountain breeding grounds. 
A few western robins were seen at Carlsbad on March 25 , but most of these familiar birds go to higher elevations to breed, some of them even to the timberline region of the mountains farther north in the state.

Eastern bluebirds were common about the cave from the time of my arrival on March 11, to about the middle of April, when they left for cooler climates. 


\section{CHAPTER 7}

\section{Reptiles of the Region}

Cold-blooded vertebrates are most numerous both as regards species and individuals in warm climates. Both Lower and Upper Austral zones are rich in reptilian life, and the cave region, combining the faunas of both of these zones, is especially so. Most of my work at the cave was too early for successful collecting, and the available notes are few, but the region is known to be of special interest to the student of herpetology.

\section{SNAKES}

The only known poisonous reptiles are rattlesnakes, of which three, and possibly five, species occur. The large western diamond-backed rattlesnake (Crotalus atrox) (Fig. 59) is found in the valley country and up to the vicinity of the great cave, and many of the local residents will tell of "hundreds" seen and killed "last year." Previous to May 2, 1924, all my efforts to find and obtain specimens of these snakes in the Carlsbad region were unsuccessful, although a dozen people were helping me watch for them. On May 2 I found a small young one that had fallen into a cave in Bob Dow's pasture and could not get out, and this was the only rattlesnake I was able to see alive or collect up to the time I left on May 9, although famous rattlesnake dens, gypsum caves, and prairie-dog towns were visited on hot days in search of them. Still later in the season 
several were seen by Doctor Lee and his assistants, and a number of others were known to have been killed in the general region during the summer. Hunting rattlesnakes, here, as elsewhere, is generally not very successful, and rarely exciting or dangerous. Nevertheless, the habit of wearing high boots or leather leggings when tramping over the desert country is to many people a source of real protection from the strain on their nerves. Some of the diamond-backed rattlesnakes grow to large size, attaining several feet in length, with thick and powerful bodies, strongly marked with a row of transver'se quadrangles along the back. On account of their large size their bite is sometimes very deep and dangerous, and every precaution should be taken to avoid being bitten by them.

The black-tailed, or green, rattlesnake (Crotalus molossus) (Fig. 61) is occasionally met with in the Guadalupe Mountains, and was perfectly described to me by Jim White, who knows it in the vicinity of the Carlsbad Cave. There are specimens from near Queen. These snakes seem to belong to the mountains rather than to the valley. They are rarely as large as the diamond-back and are generally of an olive or greenish color, sometimes having distinct bands, blotches, or diamonds along the back and velvety black tails. The danger from the bite of these or other rattlesnakes increases with their size and the amount of poison which they are able to inject into the circulation of their victim.

The prairie rattlesnakes (Crotalus confluentus) (Fig. $60)$ are found over the higher plains country to the 

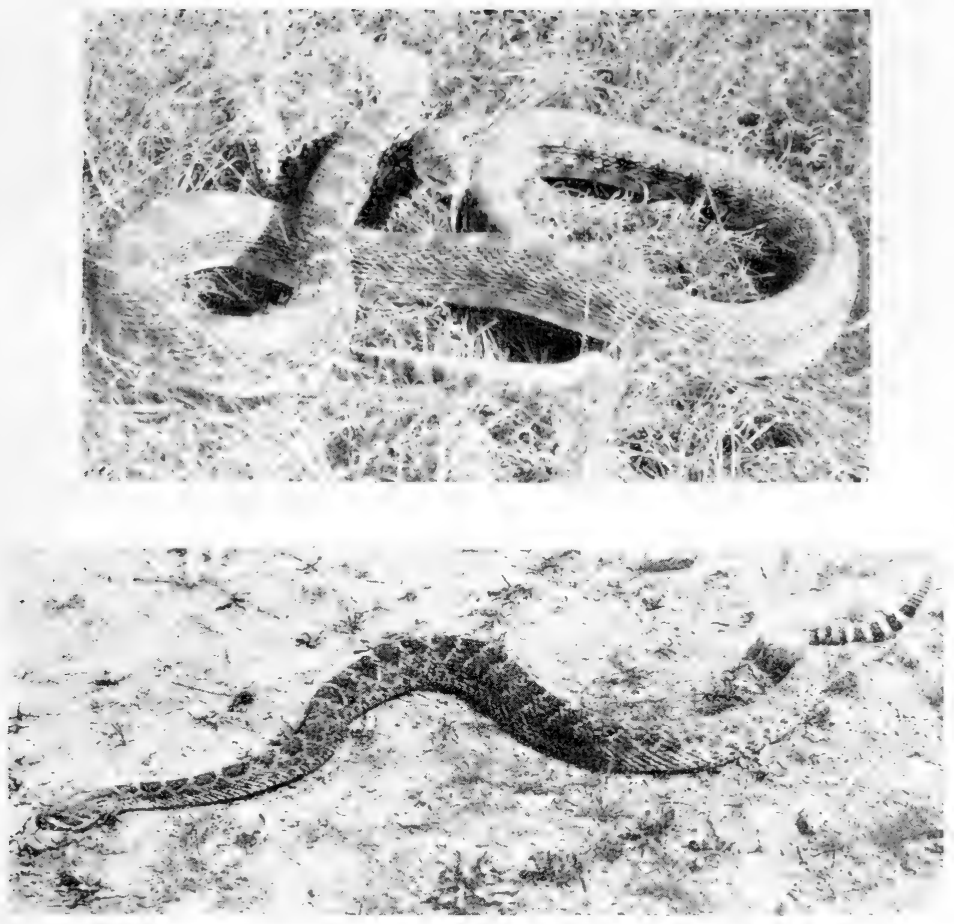

Upper: Fig. 58. Western Bull Snake

A harmless and very useful reptile found near the Carlsbad Cave. Photograph by Russell Reid, North Dakota.

Lower: Fig. 59. Diamond-backed Rattlestake from Texas

Occasionally found in the Carlsbad Cave country. Photograph by J. D. Mitchell. 

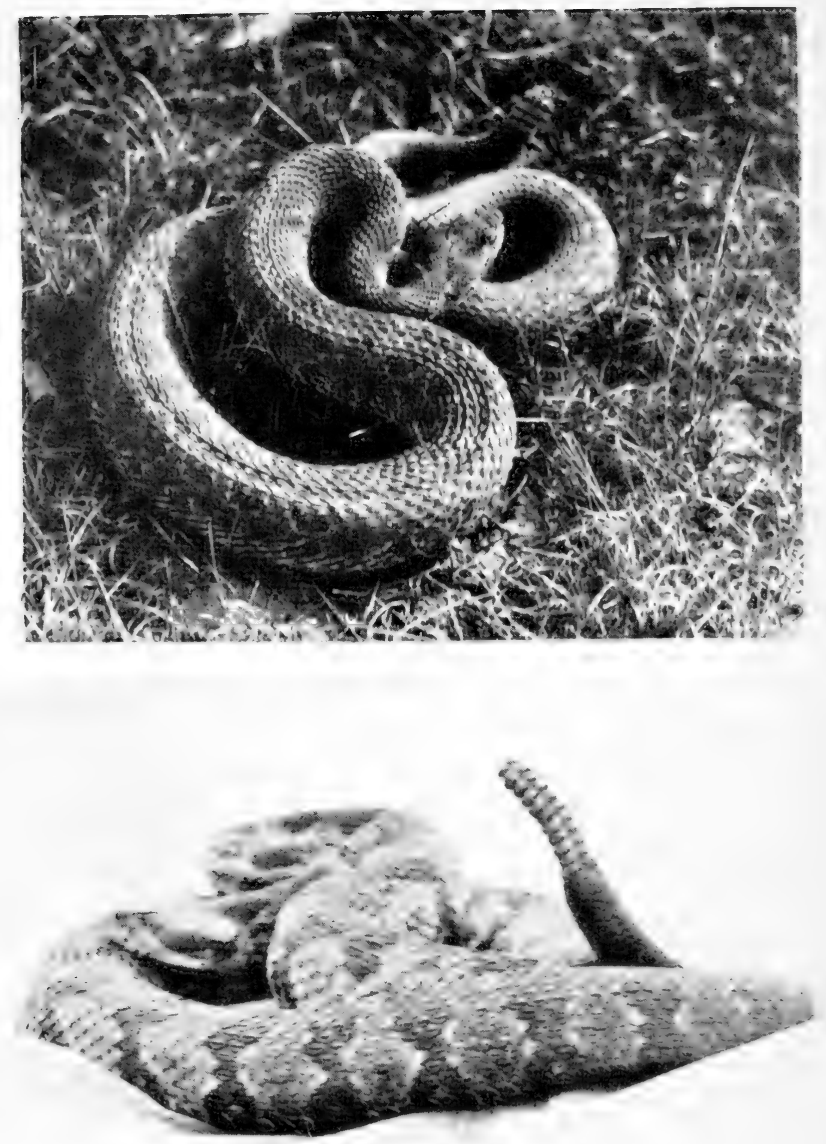

Upper: Fig. 60. The Prairie Rattlesnake Photograph by Russell Reid, North Dakota

Lower: Fig. 61. Black-tailed Rattlesnake from Texas Photograph by J. D. Mitchell 

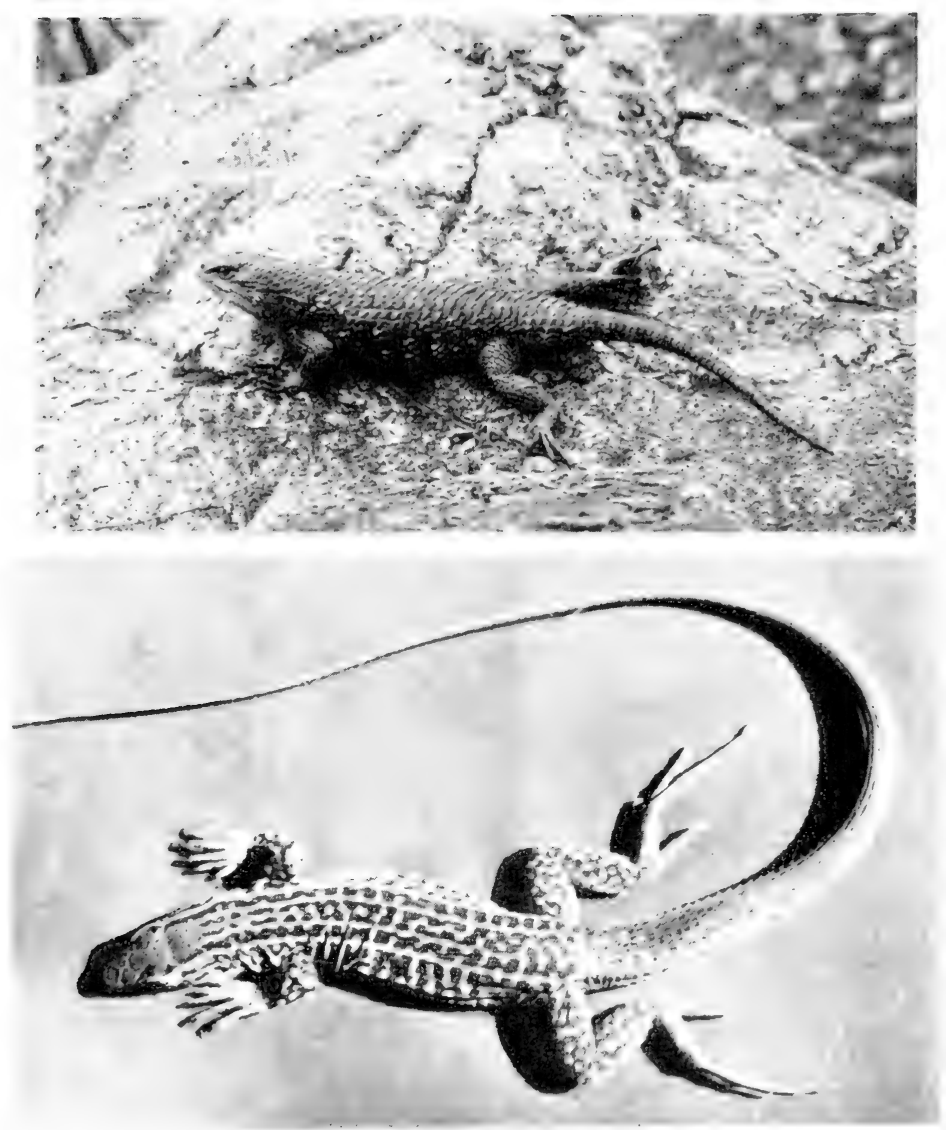

Upper: Fig. 62. Scaly Lizard (Sceloporus Clarkit)

Lower: Fig. 63. Desert Whip-tailed Lizard (Cnemidophorus tessellatus) at Carlsbad Cavern Exceedingly swift and graceful in its motions 

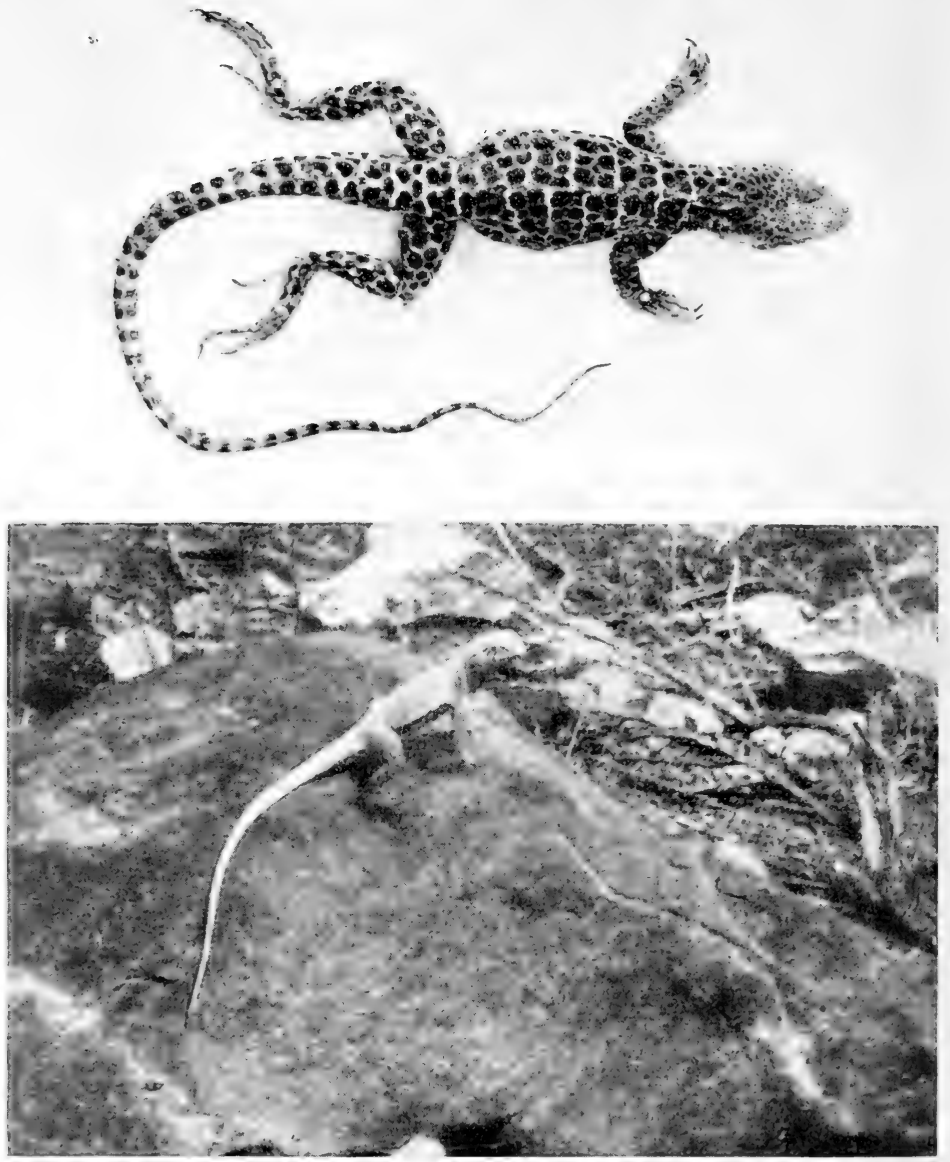

Upper: Fig. 64. Tiger Lizard (Crotaphytus wislizexii) One of the conspicuous lizards of the arid region

Lower: Fig. 65. Western Collared Lizard (Crotaphytus COLLARIS BaILEYi)

One of the most spectacular lizards of the Cave Region. Photograph by A. L. Gibson, Arizona. 
north and east, but occur also in the general region of the cave. They are smaller and duller colored than the diamond-back, or the black-tail, with no very distinctive markings.

Non-poisonous snakes of the Carlsbad Cave region include the western bull snake (Pituophis sayi) (Fig. 58), the Mexican black snake (Drymarchon corias melanurus), the coachwhip snake (Bascanion, species not determined), the ring-necked snake (Diadophis regalis regalis), and undoubtedly several water snakes and other species. All of the snakes are more or less useful in their destruction of rodents and insects, and especially in helping to maintain the general balance of nature so long established as to have become a practical working arrangement of plant and animal life. With the coming of the white man and his domesticated animals many of these natural adjustments have been disturbed and some species must be controlled through man's efforts. One of these new adjustments seems to require the partial elimination of the poisonous reptiles, and possibly of some of the tree-climbing species that feast on the eggs and young of our native birds, but the harmless snakes need not be destroyed just because they are snakes. At least let us show our intelligence by trying to know their habits and understand their natures before we kill them.

\section{LIZARDS}

Many species of lizards are seen on hot days along the roadsides, among the desert shrubs, on the rocks, 
and even running over the buildings about the cave shafts. Widely differing groups are represented, as the rough, scaly rock lizards (Fig. 62); the smooth, slender whip-tailed lizards (Fig. 63); the big, brilliantly colored collared lizards (Figs. 64 and 65); the bartailed Texas lizards; several groups of small, plainly colored and little noticed species; and two, if not three, kinds of horned lizards (Fig. 66), commonly called "horntoads." A close study at favorable seasons of the year would undoubtedly disclose many other species and groups, and possibly some forms that have not been previously recognized. All are harmless and very useful, as well as very interesting, animals, well worth a careful study of habits. Most of their food consists of insects and other small forms of animal life, the destruction of which is not only important to our human interests, but necessary in the balance of nature that tends to prevent the sudden increase of highly destructive species.

\section{TURTLES}

Turtles of several species inhabit the Pecos and Black rivers, and pieces of their bones and shells uncovered from old camp fire sites in the sand dunes along the river banks show that they had an economic value to the prehistoric tribes of this region. A small box tortoise is occasionally found along the valley at a distance from water, and even in the driest situations. This species seems perfectly adapted to desert life and is able in some way to obtain sufficient moisture for its needs. 


\section{CHAPTER 8}

\section{Invertebrates of the Carlsbad Cavern ${ }^{1}$}

Compared with other more open caves of the desert region, the Carlsbad Cavern has a very meager invertebrate fauna, consisting so far as determined of a few insects, spiders, mites, millipedes, and scorpions (Fig. $67)$.

This paucity of life is evidently due in part to the restricted openings, steep descents and great depth of the cave, but still more to the lack of organic matter to serve as food for such life. Plant life in the cave is practically limited to lichen growth in the first rooms and abundant molds throughout the cave. The only other organic matter that can serve as animal food is

${ }^{1}$ This chapter has been prepared mainly from field notes contributed by O. G. Babcock, of the U. S. Bureau of Entomology, who was detailed by F. C. Bishopp, of the Texas Division of the Bureau, to help collect the insects of the Carlsbad Cavern, and worked several days with me in the cave during the last week of April, 1924. A thorough collection even of the species in the cave could not be made in this time, and the rich and interesting outside insect and other invertebrate fauna could not be touched. The present list, however, contains some new and interesting species and suggests the possibilities of many more to be collected.

The specimens have been identified so far as possible by specialists in the Bureau of Entomology, the Diptera by C. T. Greene, the Coleoptera by H. S. Barber, the Lepidoptera by C. Heinrich, the Orthoptera by A. N. Caudell, the Siphonoptera by C. R. Shannon, and the spiders and mites by Dr. H. E. Ewing and C. R. Crosby. The cordial assistance and coöperation of the staff of the Bureau is gratefully acknowledged.-Vernon Bailey. 
derived from the bat guano, dead bats and other animals, and such dead vegetable matter as is washed in through the two natural openings.

During the twenty-year period when the guano was being removed from the cave, many workmen with food and clothing, lumber, machinery, and sacks were employed in the upper level of the cave, and some of the materials left at that time, 1901 to 1921, and other refuse left by visitors since, may have attracted some of the insects and spiders. Most of the species collected, however, seem to be the more ancient inhabitants of the cave.

When logs, stones, or boards are moved from the surface of the ground, insects and other small creeping things, beetles, spiders, bugs, centipedes and millipedes are often seen scurrying here and there in a frantic endeavor to find some dark retreat where they can hide away from the light. The longer the log, stone, or board has lain, the more numerous will be the small things living under it, if moisture and food conditions are favorable. Likewise in old abandoned burrows of mammals, in hollow banks, or in cellars, it is the rule and not the exception to find an abundance of insects and other small life hiding away from the light. Some of these are merely nocturnal species, which roam over the surface of the ground at night and take refuge by day in dark, moist cavities, while others more or less permanently inhabit such places, finding both food and lodging as well as protection from a host of natural enemies. While other insects may be diurnal and terrestrial, arboreal, arid or aquatic, according as each 

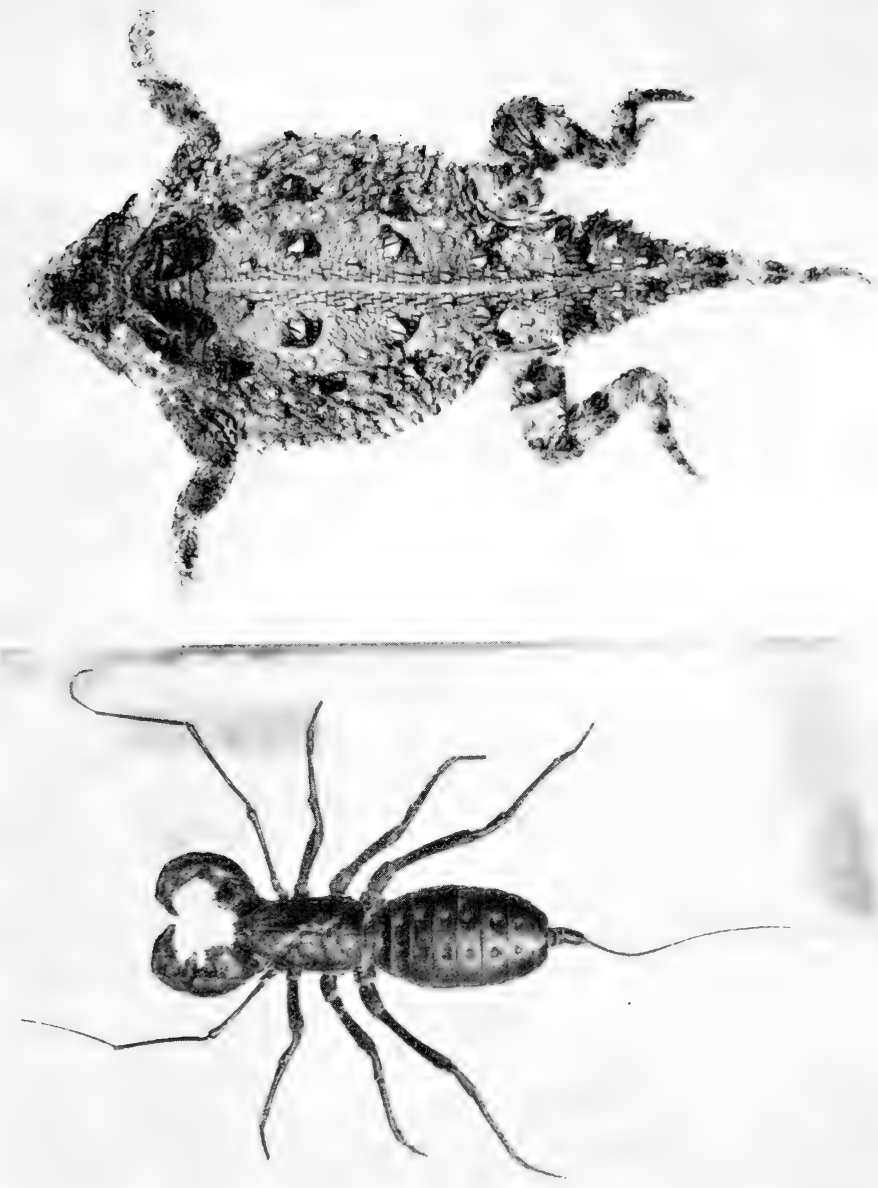

Upper: Fig. 66. Horntoad (Phrynosoma corNutum) Frequently found over the desert country

Lower: Fig. 67. The Vinegaroon or Whip Scorpion

These venomous appearing but perfectly harmless animals are extensively eaten by the owls of the caves, and parts of their shells are shown in the owl-pellet material. 

has long ago found the niche of the universe to which its structure and habits have become adjusted, so some of the subterranean species have taken to cave life and have become fully adjusted to cave conditions.

Even man, claiming supremacy in earthly intelligence, has passed through many cave and cliff-dwelling stages where advantages in safety, comfort, and convenience were won by such adaptation. It is also true that miners become in time so accustomed to working underground that they find a fascination in the underground life. And why not? The daily and seasonal variations in temperature are slight, the humidity is refreshing, and nervous strain is greatry reduced. This means bodily comfort, even though in time it may mean, with the lower forms of animal life, degeneration and the loss of many of the keenest faculties, and eventually through generations noticeable structural changes.

Such changes, however, are gradual, and only forms that have been restricted to underground life for very long periods show modifications therefrom worthy of specific recognition.

The insects and other creeping life of the Carlsbad Cavern, if those of the great arched doorway and open shaft were included, would take in most of the species of the surrounding desert region, or at least of the cliff and canyon country, but not sufficient collecting was done to include more than a part of those of the cave rooms or the regular, if not permanent, residents of the cave. The following species were collected:

Cave crickets. The most conspicuous insects in the 
cavern are two species of large, long-legged, palecolored crickets, both of which proved to be new to science and have since been described and named in the Proceedings of the Entomological Society of Washington. While generally similar in appearance, they are readily distinguished by size and color.

The Carlsbad cave-crickets (Ceutophilus carlsbadensis Caudell) are the larger and browner of the two species, with bodies about an inch in length, and very long legs and feelers. They are pale brown or yellowish in color, with small black eyes. Many were found in the first rooms of the cave where there is some trace of light from the natural openings, but mainly in darkness that to untrained human eyes seems stygian.

They were found moving slowly along the trails and over the guano-strewn floor of the bat-inhabited rooms, or hidden away under stones, boards, or old guano sacks. When approached or alarmed, they made long hops, but were generally slow and sluggish for crickets, moving slowly and touching the ground in front with the long antennae as if feeling their way. Apparently they did not see well, if at all, but a quick motion in the air or step on the ground near them, or even the bright light of the lantern flashed upon them usually caused them to move away or to make long jumps.

The opaque contents of their stomachs could usually be seen through the translucent walls of the abdomen, and a microscopic examination of the contents of a few stomachs showed mainly insect remains, evidently from bits of bat guano. Whether they ate the mold plants with which they were often closely associated was not 
fully determined. In many cases they gathered on fresh meat of rabbits, wood rats, and dead cave mice left for bait to attract other insects, and apparently ate the meat and the vegetable contents of the rabbit stomachs and intestines. Seemingly they are scavengers.

In turn they are eaten by the cave mouse, Peromyscus leucopus tornillo, and often form the principal food found in its stomach. They may also be eaten to some extent by the ring-tail, Bassariscus astutus flavus, and so have a considerable influence on the larger life of the cave.

The white cave-crickets (Ceutophilus longipes Caudell) are slightly smaller than the brown ones, with relatively longer legs, and much paler colors. The body is of a transparent whitish color, and the eyes mere black specks, which seem to be structurally normal. However, as the crickets live mainly in the lower levels of the cave beyond any possible trace of light, the eyes may possibly be functionless. They seem to have no power of sight in the light of the lantern, but were sensitive to vibrations of a footstep or of a hand waved rapidly in the air near them. The very long and slender antennae are always waving in the air, or touching the ground or objects far in advance of the body, and doubtless convey to the small cricket-mind whatever sensation is important to it.

These ghosts of crickets are frequently seen along the trails in the farthest rooms of the cave, where only slight traces of organic matter are to be found. Still the transparent bodies usually show specks of opaque 
matter in the stomach and intestines, perhaps specks of insect remains from bat droppings, or spores of the mold plants, or mere particles of decaying vegetable matter washed in long ago from the surface above, at best a meager diet that through the long ages might well have modified the bodies of these insects to their present attenuated and ethereal appearance.

The cave mice caught in the lower levels of the cave had been feeding to a considerable extent on these insects, and some of their stomachs contained nothing else. Here this mouse is supposedly the principal food of the larger ring-tail, and thus these obscure and far-away insects contribute in a humble and indirect way towards converting earthy matter into higher and higher types, each dependent upon lower forms, and each more useful in our scale of estimates.

Blow Flies. Down one hundred and seventy feet below the surface of the ground, in the first large room of the cave, the slow, heavy buzzing of a fly was heard on several occasions, but as the flies could not be detected even by the light of a powerful gasoline lantern, the insect net was useless. The deep-toned buzzing suggested a blue-bottle or blow-fly, so meat bait was tried. A freshly killed cottontail rabbit and a wood rat were cut up and pieces distributed at strategic spots. Within an hour two large blue blow-flies (Calliphora vomiteria nigribarba Shannon) were captured near the bottom of the east shaft, or bucket entrance to the cave. Others were seen on the bait, and one was found laying eggs in the meat. This was in total darkness, as the old shaft, not in use, was covered, and practically no 
light could enter. With the skeleton of a great horned owl found near the entrance of Yeitso's Den, at the extreme limit of all traces of outside light, were found numbers of the pupa cases of the blow fly maggots, identified as of the genus Calliphora and probably of this species. Thus it is evident that these flies were at home and breeding in the cave, although none was found outside, where dozens of the common black blow-fly (Phormia regina) were breeding in the carcass of a dead colt not far away. These blue-bottle or blowflies are common winter inhabitants of the southern part of the United States, where they breed in animal carcasses. It is possible that they may breed, or aestivate, in the cool caverns during the heat of summer and remain in the open during the colder seasons.

Seven other species of small flies were collected in the cave, apparently all associated with the great deposits of bat guano, and most of them attracted to fresh meat used as a bait for such insects. Of these were several specimens of tiny dung-fies (Leptocera atra Adams) and two other specimens that may represent different species. Two specimens of a little moth$f l y$ or sewer-fly (Psychoda), species not determined, were collected, one of these near fresh meat used as bait. These are scavenger flies and were probably breeding in wet places in the guano. Another little cave dung-fly (Helomyza pectinata $\mathrm{Lw}$.) was collected, and might well be common in the cave, as other members of the family have been reared from bat, rabbit, and bird dung.

Another tiny and very active little hump-backed fly 
(Aphiochaeta rufipes Mg.) was taken on a dead mouse in the bottom of the east shaft, about one hundred and seventy feet below the surface. This was on the deep beds of guano, where they probably breed. Three specimens of little false fungus-gnats of the genus Sciara, were taken near the Pulpit, west of the west entrance to the cave, where water dripping from the roof made a wet and muddy spot on the cave floor. They may have been breeding here, as species of this genus are known to breed in moist places, in rotten potatoes, and in old bark.

One specimen in poor condition of an Anthomiad fly (Phaoma, species not determined) was collected but not saved. These belong to the same family as the little house fly.

Two small crane-fies of the genus Tipula were captured on the guano at the base of the east hoisting shaft where guano was taken out years ago. As these insects are supposed generally to breed in mud and stream banks it may be that they had merely taken refuge in the cave.

Beetles of four species were found in the first large rooms of the cave where the bat guano, during thousands of years, had accumulated to great depths. All of the specimens collected were on the floor of the great rooms one hundred and fifty to one hundred and seventy feet below the surface, but not beyond the faint traces of light that come indirectly through the two natural openings overhead. From many parts of these rooms some faint, far-away trace of light can be seen, but the places where these beetles were procured were to our eyes in apparently utter darkness. 
Three of the species are unnamed, but the largest and most conspicuous one is a tenebrioid, one of the group of darkling beetles (Embaphion contusum Lec.) found also on the surface of the ground. The one specimen procured may have fallen in or merely have taken refuge in the cave. It was found about one hundred feet west of the main elevator shaft on some carcasses of mice that had been skinned for specimens. Still it may be a regular inhabitant of the cave, as another species of the genus is recorded by Doctor Schwarz as found abundantly in cellars in Nebraska.

A remarkable new species of little ground beetle of the genus Rhadine was collected under an overhanging ledge about one hundred feet west of the main elevator shaft. It is very similar in form and apparently related to the Comstockia subterranea Van Dyke, a blind, cave-inhabiting beetle so rare that it also is known from only one specimen.

Two tiny rove beetles of the genera Atheta and Oxypoda belong to a large group, the Aleocharine staphylinids, containing many unrecognized species in each genus. They are abundant in this region but appear not to be peculiar to caves. They are generally scavengers, living on decaying animal or vegetable matter, and are considered very useful.

Moths were represented by a number of specimens of one little species of the clothes moth family, Tineidae, found commonly in the guano-filled chambers of the first large rooms of the cave. They were fairly common, and often flew from the surface of the dry guano where they were evidently breeding, as pupal cases were 
collected in the guano. They are scavenger moths, the larvae feeding on dry animal remains, in this case probably on the insect remains in the bat guano.

Several moths of a larger size, a half-inch or more in length, were seen in the guano rooms, but the only specimen collected was so crushed and damaged that it could not be determined.

Fleas of two species were collected in the Carlsbad Cavern, one on a mouse and the other on bats. On a cliff mouse (Peromyscus boylii rowleyi) trapped near the west entrance to the cave on one of the inner shelves about one hundred feet below the surface were found two female fleas of the genus Ceratopsyllus, but of an undescribed species. As female fleas do not show good specific characters, more material will be necessary for a satisfactory description of the species. These mice are more abundant outside the cave than inside, so the flea is probably not restricted to the cave.

A single harvest spider or daddy long-legs (Leiobunum townsendi) was found in the cave at the bottom of the east shaft, where it may have fallen in, but more probably it had taken refuge there. They were common in the outside buildings, and were found in great abundance in some of the other caves nearby, but usually only as far back as some trace of light could penetrate, and they probably merely take refuge at certain seasons in the caves. They are harmless to man and useful in their habits of feeding upon other insects, but a quivering mass of thousands of them vibrating together on the low roof of a small cave is almost terrifying to the uninitiated. 
Mites of two species were collected, one of the family Gamasidae (undetermined genus and species), was found on a guano bat, Tadarida mexicana. The other from a cave mouse proved to be a new species of Tralaps, not yet given a name. These mites are almost microscopic lice living on the fur of mammals.

Tiny white millipedes were abundant in moist places on the cave floor, a few hundred feet west of the west entrance, near a great pile of rocks that cut off all light from Yeitso's Den. Here on damp or moist ground, near a drip from the roof one hundred feet above, they were found crawling slowly over the mud, while in a hole dug two feet deep just below the rocks, dozens were found crawling over the moist walls of clay. Not a quarter of an inch in length, and very slow in their movements, they were only noticed on close scrutiny of the black ground. Generally the millipedes are scavengers on dead or decaying organic matter, and while repulsive in habits and appearance, they serve a useful purpose in the economy of the earth.

Six specimens of another very rare flea (Sternopsillus texanus Fox), including males and females, were collected on the bats and on the guano under the bat roosts in the cave. The type of this species from a guano bat collected at Pecos, Texas, March 21, 1902, has hitherto been the only known specimen of the species, and its host may very probably have come from the Carlsbad Cavern. Two of the fleas were on guano bats caught as they were coming out of the cave, and four were found crawling or hopping in the guano under the bat roosts. One (No. 11,516) was taken from a Myotis 
evotis from Dow's Cave, near Carlsbad. There is a possibility, however, that this flea may have been in the cloth sack in which the Myotis was carried and have originally come from the guano bats.

A small bristletail of the thysanuran genus Campodea, probably a new species not yet fully identified, was collected on the floor of the cave near the entrance of Yeitso's Den where all outer light vanishes. These very primitive insects are related to the silverfish or fish moths, well known in dark corners of old houses.

Five specimens of true spiders, including three species in three different families were collected in the first large rooms where the bats live. They were on the side walls near the bottom, on the guano-strewn floor, or under old moldy guano sacks. Many old webs showed that the spiders were not rare. The species have since been named and described by $\mathrm{C}$. R. Crosby in the Proceedings of the Entomological Society of Washington. They stand as follows:

Family Pholcrdae, Physoeyclus enaulus Crosby Family Agelenidae, Tegenaria antrias Crosby Family Agriopidae, Pererigone antraca Crosby

Mr. Crosby says that none of these spiders shows special adaptation to cave life. They were evidently subsisting on the decaying vegetable matter which had washed in through the entrance of the cave, and being mixed with the bat guano, formed a slimy ooze in wet places.

A tiny crustacean, about a sixteenth of an inch in length, with relatively large pinching claws, somewhat scorpion-like, but still unidentified, was collected on 
the floor of the cave near the entrance of Yeitso's Den, at the last trace of outside light. It was found on a piece of fresh meat which had been used as insect bait and which had evidently attracted it.

A small false scorpion of the genus Chelanops, not yet specifically identified, was collected in the cave near the east elevator shaft, one hundred and seventy feet below the surface and in almost total darkness. It was on the dry beds of guano, where mites and young spiders may have furnished it food, for they are predatory arachnids related to the scorpions. 



\section{INDEX}

A

aborigines, 39 .

Acacia constricta, 11, 28.

agave, 44.

Agelenidae, 184.

Agriopidae, 184.

Aleocharine, 181.

algireta, 30,46 .

allthorn, 11, 29.

Anenaria, 19.

anhinga, 130.

antelope, 40,55 .

anthomiad fly, 180 .

Antilocapra americana americana, 55 .

Antrozous pallidus, 121 .

Apache plume, 16, 32 .

Aphiochaeta rufipes, 180.

armadillo, Texas, 60 .

ash, green, 21.

aspen, 18.

Atheta, 181.

Atriplex canescens, 32 .

avocets, 130 .

\section{B}

Baccharis, 11.

badger, Mexican, 102.

banner-tail, 83.

barberry, three-leaved, 11 .

trifoliate, 30 .

Bascanion, 169.

Bassariscus astutus flavus, 105.

bat, big brown, 122 .

big pale, 121. bat, brown, 17.

California, 129.

canyon, 129.

cave, 126.

fringed, 126.

guano, 12.

hoary, 18, 123.

house, 12, 124.

jack-rabbit, 120.

little canyon, 12.

Mexican free-tailed, 108.

red, 123.

silver, 122 .

silver-haired, 18.

bats, 4 .

hibernation, 112.

bean, coral, 28.

goat, 28.

bear, 40 .

black, New Mexico, 104.

grizzly, 49.

Texas, 104.

beaver, Mexican, 44, 82 .

beetles, 172,180 .

rove, 181 .

Bell Ranch, 50 .

Berberis trifoliata, 46.

Big Canyon, 53, 54.

bighorn, 53.

Bighorn Cave, 31, 149.

Bison bison bison, 49 .

blackbird, Brewer, 133.

、 red-winged, 133.

rusty, 133.

yellow-headed, 133. 
Black River, 20.

blow flies, 178.

bluebird, chestnut-backed, 18. eastern, 162.

blue-thorn, 11, 30 .

bobcat, 44 . mountain, 94 . plateau, 16.

B ovidae, 53.

bristle-tail, 184.

buckeye, Mexican, 11, 22.

buffalo, 40, 49 .

bunting, painted, 12, 155 .

white-winged, 133.

bush-tit, lead-colored, 160 .

buzzards, turkey, 136.

C

cactus, 11,37 .

cane, 38 .

cliff, 38 .

Devil's head, 37 .

Calliphora, 179.

Calliphora vomiteria nigribarba, 178.

Campodea, 184.

Canis latrans texensis, $\mathbf{9 5}$.

Canis mexicanus nubilus, 96 .

cardinal, 155.

Carlsbad Cavern, 2.

description, 3, 4, 5 .

location, 1 .

Castor canadensis mexicanus, 82 .

catfish, 43.

catsclaw, 16, 28.

cave bird, 150 .

cave cat, 4 .

ring-tailed, 105.

cave pearls, 3 .

Ceanothus, 46, 55, 58 . centipedes, 172.

century plant, $37,44$.

Parry, 16.

Ceratopsyllus, 182.

Cervus canadensis merriami, 56.

Ceutophilus carlsbadensis, 176 .

Ceutophilus longipes, 177 .

Chelanops, 185.

cherry, black, 21.

wild, 46.

chestnut, 20.

Chilopsis linearis, 31 .

chipmunk, 17.

Choysia dumosa, 31.

Citellus grammurus grammurus, 66.

Citellus mexicanus parvidens, 67.

clay, pottery, 48.

Comstockia subterranea, 181.

Conepatus mesoleucus mearnsi,

98.

coots, 43, 130.

coral bean, 28 .

cormorant, 130 .

Coronado, 48, 49.

Corynorhinus macrotis pallescens, 120.

cottontail, 43.

desert, 11.

mountain, 17.

small, 62.

cotton-top, 43, 133.

cottonwood, 20.

desert, 20.

cougars, 93.

cowbirds, 133.

coyote, 44 .

Texas, 95 .

crane-fly, 180 . 
cranes, 43, 130.

Cratogeomys castanops, 91. creeper, Rocky Mountain, 18. creosote bush, 11, 15, 27. crickets, cave, 4, 175 .

Carlsbad cave, 176. white cave, 177.

crossbill, 18.

Crotalus atrox, 163.

Crotalus confluentus, 164.

Crotalus molossus, 164.

crown of thorns, 29.

crucifixion plant, 29 .

crustacean, 184.

cuckoo, yellow-billed, 147.

curlews, 130.

currants, wild, 46.

Cynomys ludovicianus, 68.

\section{D}

daddy long-legs, 182.

Dalea, 29.

Dark Canyon, 53, 157.

Dasylirion leiophyllum, 34 .

Dasypus novemcinctus texanus, 60.

deer, 40 .

mule, 17.

gray, 16, 40, 58 .

white-tailed, 17.

plains, 57.

devil's walking stick, 27.

Diadophis regalis regalis, 169 .

Didelphis virginianus, 59 .

Dipodomys merriami merriami, 86.

Dipodomys spectabilis baileyi, 83.

Drymarchon corias melanurus, 169. ducks, 43, 130.

dung-flies, 179.

E

eagles, golden, 136, 139.

elk, 40.

Merriam, 18, 40, 49, 56.

Embaphion contusum, 181.

Empidonax, 150.

Eptesicus fuscus, 121, 122.

Erigeron, 19.

Espejo, Antonio de, 50.

F

falcon, prairie, 139 .

Fallugia paradoxa, 32 .

Felis couguar aztecus, 93.

Felis hernandesii, 92.

Fiber zibethicus ripensis, 81 .

finch, Mexican house, 155.

fir, 18 .

fleas, 182.

flicker, red-shafted, 17, 148.

fly, hump-backed, 179.

flycatcher, ash-throated, 150.

olive-sided, 18.

scissor-tailed, 150.

Fouquieria splendens, 27.

fox, gray, 16,44 .

gray, Arizona, 95.

Franks Canyon, 53.

G

Gamasidae, 183.

Garden Canyon, 26, 160.

geese, 43, 130.

gnatcatcher, plumbeous, 12.

western, 161.

gnats, fungus, 180 .

goat, angora, 58 . 
goat bean, 28 .

goldfinch, 156.

gooseberries, wild, 46 .

grapes, wild, 46.

grass, bear, 33, 47.

sweet, 47.

tobasa, 15.

grease-brush, 32 .

grebes, 130 .

grinding-holes, 39, 45

grosbeak, western blue, 155 .

ground squirrel, 43.

Mexican, 67.

Rio Grande striped, 11.

thirteen-lined, 17.

Guadalupe Canyon, 53.

guano, 2, 5, 108, 113.

Gunsight Canyon, 53.

$\mathrm{H}$

hackberry, 16, 22, 46.

havelin, 59 .

hawk, ferruginous rough-legged,

136, 139.

marsh, 136.

sparrow, 139.

Swainson, 136, 139.

western red-tailed, 136, 139.

zone-tailed, 139.

Heleodytes, 158.

Helomyza pectinata, 179 .

herons, 43, 130 .

horntoad, 18, 170 .

desert, 16.

hummingbirds, 149 .

black-chinned, 149 .

blue-throated, 150 .

broad-tailed, 17, 150 .

hydrophobia cats, 102.

insects, 4 .

Indians, 39.

Apache, 48.

Mescalero, 47.

jaguar, 92 .

jay, long-crested, 18.

pinyon, 16.

Woodhouse, 16, 152.

joint fir, 29.

junco, 133, 156.

gray-headed, 18.

juniper, 15, 22.

blue-leaved, 22.

checker-barked, 22.

mountain, 22.

round-topped, 22.

K

kangaroo rat, Merriam, 86 .

kingbird, Arkansas, 150 .

Cassin, 12, 150.

kinglet, golden-crowned, 18, 161 .

ruby-crowned, 18.

western, 161 .

L

Lachnosterna, 98.

lark, horned, 16, 133, 151.

Lasionycteris noctivagans, 122 .

lechuguilla, 11, 37, 44.

Leguminosae, 28.

Leiobunum townsendi, 182.

Leptocera atra, 179.

Lepus californicus texianus, 60 .

Life Zones, 7.

Austral, Lower, 8. 
Life Zones, Austral, Upper, 8, 15. Canadian, 8, 18.

Hudsonian, 18.

Sonoran, Lower, 8.

Sonoran, Upper, 15.

Transition, 8, 16.

Ligusticum, 19.

lizards, 169.

Clark scaly, 12.

collared, 170.

leopard, 12.

Poinsett scaly, 16.

scaly fence, 16 .

scaly rock, 170 .

Texas, 170.

Texas horned, 12.

Texas spotted-tailed, 12.

western collared, 16.

whip-tailed, 12, 170.

Llano Estacado, 53.

lobos, 96.

locust, New Mexico, 17, 26.

longspurs, 133.

Lynx rufus uinta, 94.

\section{M}

McKenzie Ranch, 50.

McKittrick Canyon, 53.

McKittrick Cave, 120, 125.

madrone, Mexican, 20.

mahogany, mountain, 16, 55, 58.

Mammillaria, 46.

manzanita, 16, 46, 58.

maple, large-leaved, 17.

New Mexico, 21, 46.

meadowlark, 133.

western, 152.

meadow mouse, Guadalupe, 17.

Rocky Mountain, 18.

Mephitis mesomelas varians, 97. mescal, 37, 44.

mescal pits, 39, 45.

Mescalero Cave, 56.

mesquite, 11, 25, 28, 45.

millipedes, 171, 183.

Mimosa biuncifera, 28.

mints, 47 .

mites, 171, 183.

mockingbird, western, 12, 157.

Mormon tea, 29.

moth-fly, 179.

moths, 181.

mountain lion, gray, 93 .

mourning dove, 135 .

mouse, cave, 11, 69.

cliff, 73.

grasshopper, 74 .

pocket, 12, 89 .

Baird, 89, 90.

Dutcher, 89, 90.

Kansas, 89, 90.

white-footed, Rowley, 16.

mulberry, 16, 22.

muskrat, Pecos, 44.

Pecos River, 81.

mussels, 43 .

Mustela frenata neomexicana,

97.

Myotis californicus pallidus, 129 .

Myotis incautus, 124.

Myotis thysanodes, 126 .

Myotis velifer, 126.

\section{$\mathrm{N}$}

Neotoma albigula, 43, 75 .

Neotoma micropus, 43.

Neotoma micropus canescens, 79.

nighthawk, Texas, 12, 148.

western, 148.

nutcracker, Clark, 19. 
nuthatch, pygmy, 18.

red-breasted, 18.

Rocky Mountain, 18.

Nycteris borealis, 123 .

Nycteris cinerea, 123.

\section{$\mathrm{O}$}

oaks, 20.

gray, 16.

New Mexico, 17.

scrub, 21, 58.

Vasey, 16.

Oak Springs, 20.

ocotilla, 11, 15, 27.

Odocoileus hemionus canus, 58.

Odocoileus virginianus macrourus, 57.

onions, wild, 45.

Onychomys leucogaster ruidosae, 74 .

Onychomys torridus, 74 .

opossum, Virginia, 59.

oriole, Bullock, 155.

hooded, 12.

Scott, 12, 152.

Sennett, 155.

Orthocarpus, 19.

Ovis canadensis texiana, 53.

owl, barn, 140.

burrowing, 140 .

great horned, 140 .

screech, 17, 140.

spotted, 17, 140.

Oxypoda, 181.

\section{P}

panthers, 93.

Parosela formosa, 29.

Pecari angulatus angulatus, 59 . peccary, 59.
Pererigone antraca, 184.

Perognathus, 89.

Perognathus flavus, 89.

Perognathus hispidus paradoxus, 89.

Perognathus merriami gilvus, 89.

Peromyscus boylii rowleyi, 73 .

Peromyscus leucopus tornillo, 69.

petaya, 46.

phalaropes, 130 .

Phaoma, 180.

phoebe, Say, 150.

Pholcidae, 184.

Phormia regina, 179.

Physoeyclus enaulus, 184 .

pigeon, band-tailed, 17, 135 .

pine, nut, 16, 22.

white, southern, 17 .

yellow, 20, 25.

western, 17 .

pine siskin, 18.

pinyons, 22, 47.

Pipistrellus hesperus hesperus, 129.

pipit, 19.

Pituophis sayi, 169.

plovers, 130.

pocket gopher, 43.

chestnut, 91 .

fulvous, 17 .

lechuguilla, 12, 90 .

poniel, 32 .

poor-will, 16, 148.

popotillo, 29.

potatoes, wild, 45 .

prairie dog, black-tailed, 68 .

prairie-dog towns, 43.

prickly pear, 38,46 .

Procyon lotor mexicanus, 105. 
pronghorn, 55 .

Psychoda, 179.

Q

quail, blue, 133 .

fool, 43, 134.

Mearns, 16, 43, 134.

scaled, 43, 133.

$\mathrm{R}$

rabbit brush, 16 .

rabbit, jack, 40.

jack, Texas, 11, 60.

raccoon, 44.

Mexican, 105.

rat, cotton, 11,81 .

kangaroo, 11, 43, 83, 86.

Rattlesnake Canyon, 53.

raven, 16.

white-necked, 12, 152.

Rhadine, 181.

Khodiola, 19.

ring-tails, 4, 44 .

road-runner, 12, 147 .

robin, western, 18,162 .

rose, cliff, 32 .

\section{S}

sages, 47 .

sandpipers, 130.

Sarcobatus vermiculatus, 32 .

Saxifraga, 19.

Sciara, 180.

scorpion, 171.

false, 185 .

Sedum, 19.

service berry," 16,46 .

shadscale, gray, 32 .

sheep, mountain, 40.

mountain, Texas, 16, 53. shrew, 18.

shrikes, white-rumped, 157.

Sigmodon hispidus berlandieri, 81.

Silene, 19.

silk tassel bush, 16 .

skunk, 44.

bush, 16, 30, 47 .

hog-nosed, 98.

little Rio Grande spotted, 101.

long-tailed Texas, 97.

Mearns white-backed, 12.

Rio Grande spotted, 12.

Texas, 12.

Slaughter Canyon, 25, 31, 53, 58. snakes, 163.

coachwhip, 169.

black, Mexican, 169.

bull snake, prairie, 16.

western, 169.

garter, western, 18.

rattlesnakes, 163 .

black-tailed, 16, 164 .

diamond-back, Texas, 12. western, 163.

green, 164 .

plains, 16.

prairie, 164.

ring-necked, 169.

snipe, 130.

soapweed, 47.

solitaire, Townsend, 19.

sotol, 11, 20, 33, 34, 45.

Spanish bayonets, 33 .

sparrow, black-chinned, 16 .

black-throated, 156.

Cassin, 155.

desert, 12.

rock, 156 .

Scott, 16. 
sparrow, western chipping, 156. western lark, 156. western vesper, 156 .

white-crowned, 18, 156.

spiders, 171, 184.

harvest, 182.

Spilogale leucoparia, 101.

spruce, 18.

Douglas, 17.

Engelmann, 19.

squirrel, rock, 16, 43, 66 .

White Mountain spruce, 18. istar leaf, 16, 31.

Sternopsillus texanus, 183.

istilt, black-necked, 130 .

sumac, 30.

evergreen, 30 .

green, 11.

small-leaved, 11, 30.

swallow, bank, 157 .

barn, 157 .

cliff, 157.

violet-green, 157.

white-bellied, 157.

swans, 130.

swift, white-throated, 149.

Sylvilagus auduboni minor, 62 . syringa, wild, $16,31,55,58$.

$\mathrm{T}$

Tadarida mexicana mexicana, 108.

tanager, Cooper, 16, 157.

hepatic, 157.

Louisiana, 157.

mountain, 18, 157.

Taxidea berlandieri, 102 .

tea, wild, 46.

Tegenaria antrias, 184. tenebrioid, 181.

Thomomys lachuguilla, 90.

thrasher, curved-billed, 157.

thrush, Audubon hermit, 18.

Sierra hermit, 161.

Tineidae, 181.

Tipula, 180.

tobacco, wild, 46.

tortoise, box, 170 .

towhee, arctic, 156.

canyon, 16, 156.

green-tailed, 17, 156.

spurred, 18.

Tralaps, 183.

trees, 20.

turkey, Merriam, 17, 135.

wild, 40.

turtles, 170 .

hard-shelled, 43.

soft-shelled, 43.

U

unicorn plant, 47.

Urocyon cinereoargenteus scottii, 95.

Ursus americanus amblyceps, 104.

Ursus texensis texensis, 104.

V

varnish bush, 11, 15 .

verdin, 161 .

vireos, 133.

W

walnut, black, 21, 45 .

Walnut Canyon, 4, 53, 98.

wapiti, Arizona, 56. 
warblers, 133.

Audubon, 18.

Grace, 18.

weasel, New Mexico bridled, 97. willets, 130 .

willow, desert, 11, 31.

wolf, gray, 96.

woodpecker, ant-eating, 17, 148.

cactus, $12,147$.

hairy, 17.

Lewis, 148.

wood rat, 11, 43.

Colorado, 17.

gray, 79 .

white-throated, 16, 75 . wren, cactus, 12,158 .

canyon, 159.

rock, 159.

yellowlegs, 130 .

yueca, 20, 33, 47.

banana-fruited, 16.

large-fruited, 11.

narrow-leaved, 11.

Yucca macrocarpa, 33, 34.

Yucca radiosa, 33, 47.

$\mathrm{Z}$

Zizyphus lycioides, 30 . 



\section{Sans Tache}

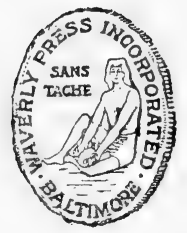




\section{Sans Tache}

TN THE "elder days of art" each artist or craftsman enjoyed the privilege of independent creation. He carried through a process of manufacture from beginning to end. The scribe of the days before the printing press was such a craftsman. So was the printer in the days before the machine process. He stood or fell, as a craftsman, by the merit or demerit of his finished product.

Modern machine production has added much to the worker's productivity and to his material welfare; but it has deprived him of the old creative distinctiveness. His work is merged in the work of the team, and lost sight of as something representing him and his personality.

Many hands and minds contribute to the manufacture of a book, in this day of specialization. There are seven distinct major processes in the making of a book: The type must first be set; by the monotype method, there are two processes, the "keyboarding" of the MS and the casting of the type from the perforated paper rolls thus produced. Formulas and other intricate work must be hand-set; then the whole brought together ("composed") in its true order, made into pages and forms. The results must be checked by proof reading at each stage. Then comes the "make-ready" and press-run and finally the binding into volumes.

All of these processes, except that of binding into cloth or leather covers, are carried on under our roof. 
The motto of the Waverly Press is Sans Tache. Our ideal is to manufacture books "without blemish"-worthy books, worthily printed, with worthy typography-books to which we shall be proud to attach our imprint, made by craftsmen who are willing to accept open responsibility for their work, and who are entitled to credit for creditable performance.

The printing craftsman of today is quite as much a craftsman as his predecessor. There is quite as much discrimination between poor work and good. We are of the opinion that the individuality of the worker should not be wholly lost. The members of our staff who have contributed their skill of hand and brain to this volume are:

Proof Room: Sarah Katzin, Alice Reuter, Mary Reed, Lucile Bull, Ruth Treischman, Angeline Eifert, Ethel Strasinger, Dorothy Strasinger, Audrey Tanner, Lillian Gilland, Ida Zimmerman, Catherine Miller, Shirley Seidel.

Casters: Kenneth Brown, Ernest Wann, Mahlon Robinson, Charles Aher, George Smith, Martin Griffen, Henry Lee, Charles Fick, George Bullinger.

Cutter: William Armiger.

Folder: Lawrence Krug, Shipley Dellinger.

Composing Room: George Moss, Arthur Baker, Robert Lambert, James Jackson, Ray Kauffman, Anthony Wagner, Edward Rice, Richard King, Theodore Nilson, Henry Shea.

Keyboard: Mary Franck, Helen Twardowicz, Anna Rustic.

Press: Thomas Shreck, Andrew Becker, Raymond Bauer, Emory Parsons, George Lyons. 


\title{
Anatomy of the Wood Rat
}

\author{
By A. Brazier Howell
}

A study in the comparative anatomy of the subgenera of the American wood rat (genus Neotoma), illustrated with 37 figures, 8 in color, and 3 half-tones. A study of great interest to the biologist, the zoologist, etc.

Monographs of the American Society of Mammalogists Number One. $\$ 5.00$

\section{The Beaver \\ Its Work and Its Ways \\ By EDWARD R. WARREN}

The first adequate study of the beaver in North America produced in half-a-century. Based upon a full knowledge of all past writings and a large personal observation. Scientifically accurate, yet simple and readable in style.

Monographs of the American Society of Mammalogists Number Two. $\$ 3.00$

\section{THE WILLIAMS \& WILKINS COMPANY}

Publishers of Scientific Books and Periodicals

BALTIMORE, U.S.A. 





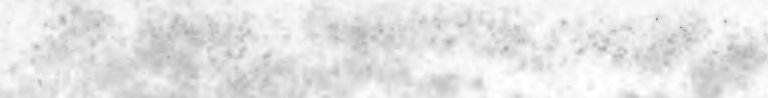

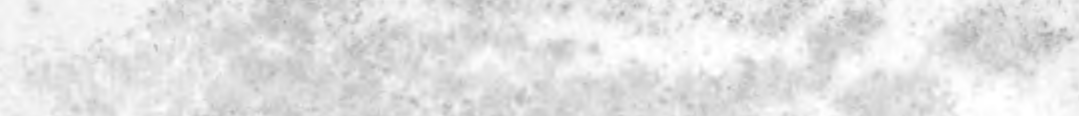
4.7.

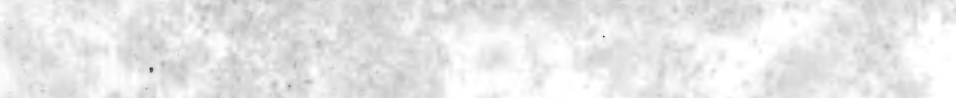

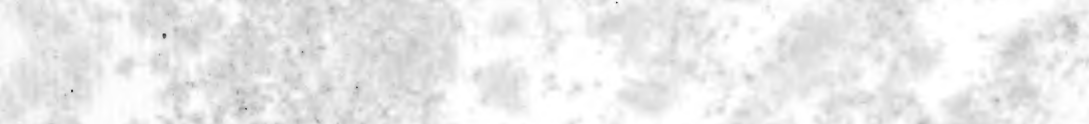

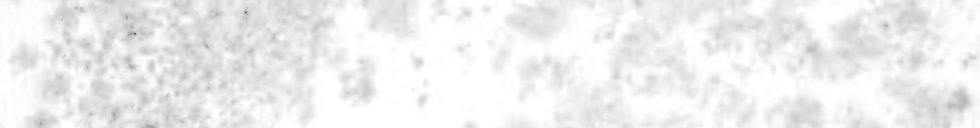

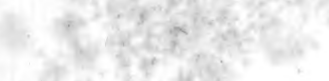

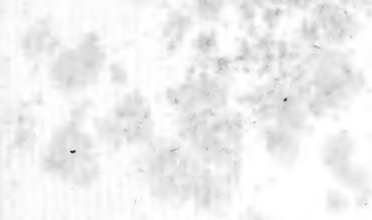

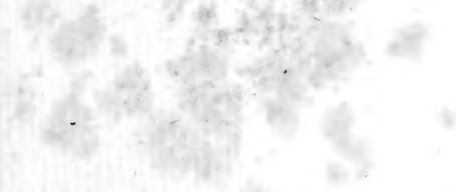

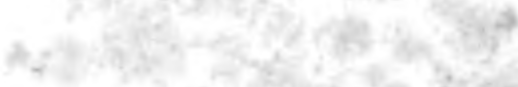

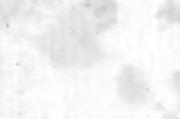

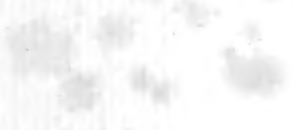

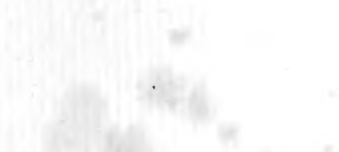

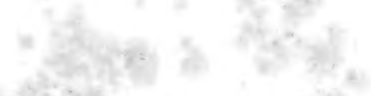

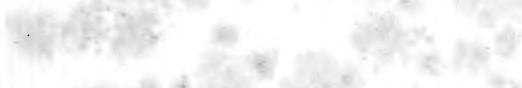

Hen

is

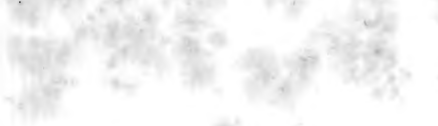

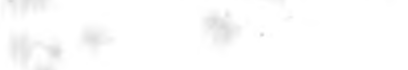

9

$+$

*4)<smiles>C1CCCC1</smiles>

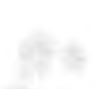

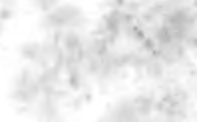

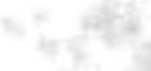

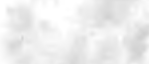
$+2$<smiles>C1CCCC1</smiles><smiles>CCC</smiles>

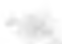

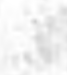

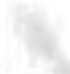

$4 \ln ^{2} \sin ^{2}$

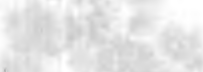

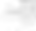

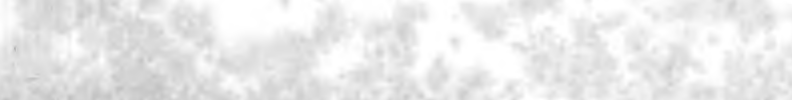

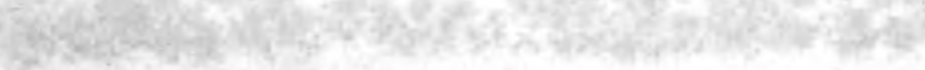


